\title{
GROUND-WATER RESOURCES OF RUSK COUNTY, TEXAS
}

By W.M. Sandeen

U.S. GEOLOGICAL SURVEY

Open-File Report 83-757

Prepared in cooperation with the TEXAS DEPARTMENT OF WATER RESOURCES

Austin, Texas

1984 
UNITED STATES DEPARTMENT OF THE INTERIOR

WILLIAM P. CLARK, Secretary

GEOLOGICAL SURVEY

Dallas L. Peck, Director

For additional information write to:

For sale by:

District Chief

U.S. Geological Survey

649 Federal Building

300 E. Eighth Street

Austin, TX 78701
Open-File Services Section Western Distribution Branch U.S. Geological Survey, MS 306 Box 25425, Denver Federal Center Denver, CO 80225

Telephone: (303) 234-5888 
Abstract-1

Introduction-

Location and extent of area-

Purpose and scope-_. 3

Methods of investigation

Physiography, drainage, and climate- 5

Economic development-_. 8

Population-_. 8

Previous investigations 8

Well-numbering system- 11

Acknowledgments

Geologic framework and physical characteristics of the

geologic units-_. 12

Midway Group-_._- 22

Wilcox Group- 24

Carrizo Sand-_. 24

Reklaw Formation- 24

Queen City Sand-_- 24

Weches Formation-_. 26

Sparta Sand-- 26

Terrace deposits and alluvium- 26

Hydrologic units-ar 26

Wilcox aquifer-a. 26

Carrizo aquifer- 27

Other aquifers-1.20 27

Ground-water hydrology- 27

Source and occurrence- 27

Recharge, movement, and discharge of ground water. 32

Hydraulic characteristics of the aquifers

Quality of ground water- 38

Water-quality criteria and standards 38

Aquifers and geologic units- 39

Midway Group 39

Wilcox aquifer-ar 41

Carrizo aquifer-an 41

Other aquifers and geologic units- 42

Contamination and protection of ground water-a 42

Surface casing- 42

Disposal of saltwater- 44

Contamination- 44

Development and use of ground water-a 46

History of development- 46

Use of water- 47

Municipal Use-_._. 47

Industrial use-1- 51

Mining use-1 51

Changes in water levels

Well construction- 54 


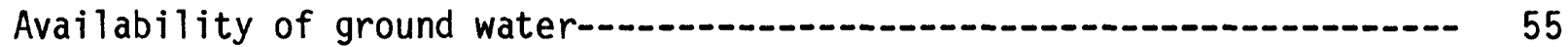

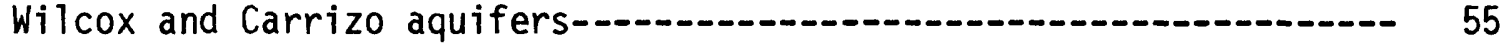

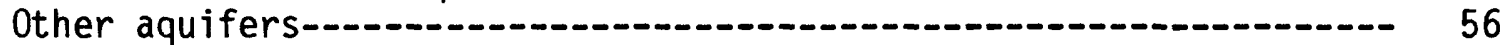

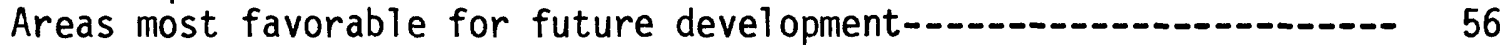

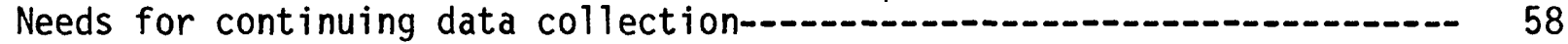

Conclusions--.-.-- 58

Selected references--- 60

Supplemental information- 64 
Page

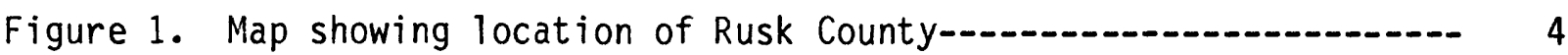

2. Graph showing annual precipitation at Henderson, 1909-80-...- 6

3. Graph showing average-monthly precipitation and temperature at Henderson and average-monthly gross-lake surface

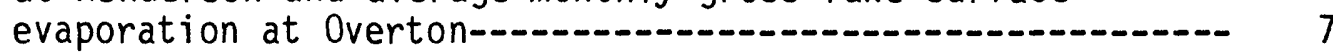

4. Photograph showing C. M. (Dad) Joiner, Dr. Lloyd, H. L. Hunt, and drilling crew of No. 3 Daisy Bradford, discovery well of East Texas 0il Field (1930)-.-.-.--.---- 9

5. Map showing location of significant oil and gas fields-.....-. 10

6. Di agram showing well-numbering system-_......................-. 13

7-9. Maps showing:

7. Location of wells, springs, and selected test holes-_-.......- 14

8. Location of principal geologic structural features in

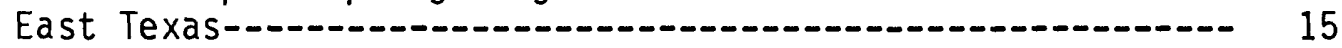

9. Geologic units in Rusk County-................................. 16

10-12. Geologic sections:

10. A-A' -17

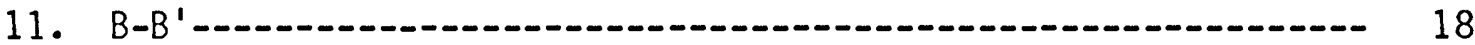

12. $C-C^{\prime}-\ldots+\ldots$

13-16b. Maps showing:
13. Approximate altitude of the base of the Wilcox Group---.--.--- 23

14. Approximate altitude of the top of the Wilcox Group--------- 25

15. Approximate thickness of freshwater-bearing sands in the Wilcox aquifer--.-.-.-.- 28

16a. Approximate altitude of the base of freshwater-............-.- 29

16b. Approximate altitude of the base of slightly saline

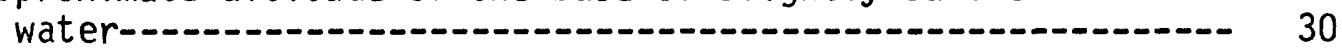

17. Photograph showing ground water seeping from sand layers in the Carrizo aquifer at the Ross clay pit north of the city of Henderson-1..... 31

18. Map showing approximate altitude of the potentiometric surface of the Wilcox aquifer, 1979-81-.......-...-.-.-. 33

19. Graph showing relationship of drawdown to transmissivity

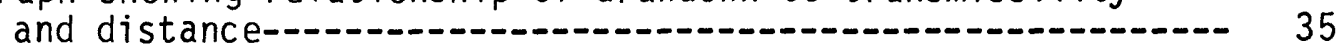

20. Graph showing relationship of drawdown to time and distance as a result of pumping under artesian

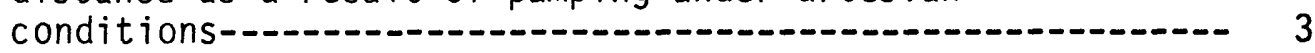

21. Map showing total dissolved-solids concentrations in water from selected wells screened in the Wilcox, Carrizo, and Queen City aquifers and in the Reklaw Formation, 1981------

22. Graph showing relationship between surface-casing requirements and the base of fresh to slightly saline

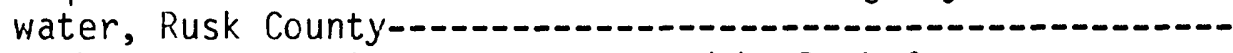

23. Map showing approximate areas served by Rusk County

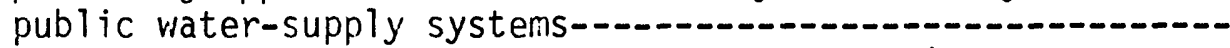

24. Photograph showing water-storage tank at Mobil's T. 0. Mason pressure-maintenance project in East Texas $\mathrm{Oil}$

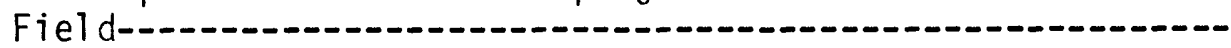


Figure 25. Hydrographs showing fluctuations of water levels in selected wells in Rusk and Cherokee Counties-_._._._.-_ 53

26. Map showing locations of areas favorable for future development of ground water-

\section{TABLES}

Table 1. Records of wells, springs, and test holes in Rusk County and adjacent areas-_. 65

2. Drillers' logs of selected wells in Rusk County-_._- 85

3. Water levels in wells in Rusk and Cherokee Counties_......... 99

4a. Water-quality data for ground-water samples collected from wells in Rusk and Cherokee Counties._._........... 106

4b. Concentrations of metals and trace elements in water from wells and springs in Rusk County-_... 114

5. Cross reference of well numbers in Rusk County-_._. 20

6. Geologic units and their water-bearing properties in Rusk County-.... 21

7. Results of aquifer tests in Cherokee, Gregg, and Nacogdoches Counties-_. 37

8. Source and significance of dissolved-mineral constituents and properties of water-... 115

9. Saltwater production and disposal, East Texas 0il Field-_-.--- 45

10. Approximate withdrawals of ground water during 1960, 1970, and 1980, in Rusk County- 49

11. Municipal use of ground water in Rusk County- 50 


\section{METRIC CONVERSIONS}

For those readers interested in using the metric system, the metric equivalents of inch-pound units of measurements are given in parentheses. The inchpound units of measurements used in this report may be converted to metric units by the following factors:

From Multiply by

\begin{tabular}{|c|c|c|}
\hline $\begin{array}{l}\text { acre } \\
\text { acre-foot } \\
\text { barrel } \\
\text { cubic foot per second }\left(\mathrm{ft}^{3} / \mathrm{s}\right)\end{array}$ & $\begin{array}{l}0.4047 \\
0.001233 \\
0.1590 \\
0.02832\end{array}$ & $\begin{array}{l}\text { hectare } \\
\text { cubic hectometer }\left(\mathrm{hm}^{3}\right) \\
\text { cubic meter }\left(\mathrm{m}^{3}\right) \\
\text { cubic meter per second } \\
\left(\mathrm{m}^{3} / \mathrm{s}\right)\end{array}$ \\
\hline foot & 0.3048 & meter $(m)$ \\
\hline foot per day $(\mathrm{ft} / \mathrm{d})$ & 0.3048 & meter per day $(\mathrm{m} / \mathrm{d})$ \\
\hline foot per mile $(\mathrm{ft} / \mathrm{mi})$ & 0.189 & meter per kilometer $(\mathrm{m} / \mathrm{km})$ \\
\hline $\begin{array}{l}\text { foot squared per day }\left(\mathrm{ft}^{2} / \mathrm{d}\right) \\
\text { gallon per day }(\mathrm{gal} / \mathrm{d})\end{array}$ & $\begin{array}{l}0.0929 \\
0.003785\end{array}$ & $\begin{array}{l}\text { meter squared per day }\left(\mathrm{m}^{2} / \mathrm{d}\right) \\
\text { cubic meter per day }\left(\mathrm{m}^{3} / \mathrm{d}\right)\end{array}$ \\
\hline gallon per minute (gal/min) & $\begin{array}{l}0.06308 \\
0.003785\end{array}$ & $\begin{array}{l}\text { liter per second }(\mathrm{L} / \mathrm{s}) \\
\text { cubic meter per minute } \\
\left(\mathrm{m}^{3} / \mathrm{min}\right)\end{array}$ \\
\hline inch & 25. & millimeter (mm) \\
\hline $\begin{array}{l}\text { micromhos per centimeter } \\
\text { at } 25^{\circ} \text { Celsius }\end{array}$ & & $\begin{array}{l}\text { microsiemens per centimeter } \\
\text { at } 25^{\circ} \mathrm{Celsius}\end{array}$ \\
\hline mile & 1.609 & kilometer $(\mathrm{km})$ \\
\hline $\begin{array}{l}\text { million gallon per day } \\
\text { (Mgal/d) }\end{array}$ & 0.04381 & $\begin{array}{l}\text { cubic meter per second } \\
\left(\mathrm{m}^{3} / \mathrm{s}\right)\end{array}$ \\
\hline square mile & $\begin{array}{r}3,785 \\
2.590\end{array}$ & $\begin{array}{l}\text { cubic meter per day }\left(\mathrm{m}^{3} / \mathrm{d}\right) \\
\text { square kilometer }\left(\mathrm{km}^{2}\right)\end{array}$ \\
\hline
\end{tabular}

Temperature data in this report are in degrees Celsius $\left({ }^{\circ} \mathrm{C}\right)$ and may be converted to degrees Fahrenheit $\left({ }^{\circ} \mathrm{F}\right)$ by the following formula: ${ }^{\circ} \mathrm{F}=1.8\left({ }^{\circ} \mathrm{C}\right)+32$. 
In this report certain technical terms, including some that are subject to different interpretations, are used. For convenience and clarification, these terms are defined as follows:

Acre-foot - The volume of water required to cover 1 acre to a depth of 1 foot $\overline{\left(43,560 \mathrm{ft}^{3}\right.}$ or 325,851 gallons).

Acre-foot per year - One (1) acre-foot per year equals $892.13 \mathrm{gal} / \mathrm{d}$.

Aquifer - A formation, group of formations, or part of a formation that contains sufficient saturated permeable material to yield significant quantities of water to wells and springs.

Aquifer test, pumping test - The test consists of the measurement, at specific intervals, of the discharge and water level of the well being pumped and the water levels in nearby observation wells. Formulas have been developed to show the relationship of the yield of a well, the shape and extent of the cone of depression, and the properties of the aquifer such as the specific yield, porosity, hydraulic conductivity, transmissivity, and storage coefficient.

Artesian aquifer, confined aquifer - Artesian (confined) water occurs where an aquifer is overlain by rock of lower hydraulic conductivity (e.g., clay) that confines the water under pressure greater than atmospheric. The water level in an artesian well will rise above the level at which it was first encountered in the well. The well may or may not flow.

Barrel - A volume of 42 gallons.

Brine - Water containing more than $35,000 \mathrm{mg} / \mathrm{L}$ (milligrams per liter) dissolved solids (Winslow and Kister, 1956, p. 5).

Cone of depression - Depression of the water table or potentiometric surface surrounding a discharging well or group of wells (usually shaped like an inverted cone).

Dip of rocks, attitude of beds - The angle or amount of slope at which a bed is inclined from the horizontal ; direction also is expressed (for example, 1 degree southeast or $90 \mathrm{ft} / \mathrm{mi}$ southeast).

Drawdown - The lowering of the water table or potentiometric surface caused by pumping (or artesian flow). In most instances, it is the difference, in feet, between the static level and the pumping level.

Electric log - A graph showing the variation in relationship between the electrical properties of the rocks and their fluid contents penetrated in a well. The electrical properties are natural potentials and resistivities to induced electrical currents, some of which are modified by the presence of the drilling mud.

Freshwater - Water containing less than $1,000 \mathrm{mg} / \mathrm{L}$ dissolved solids (Wins Tow and Kister, 1956, p. 5).

Ground water - Water in the ground that is in the saturated zone from which wells, springs, and seeps are supplied.

Head, static - The height above a standard datum of the surface of a column of water (or other liquid) that $c$ an be supported by the static pressure at a given point.

Hydraulic conductivity - The rate of flow of a unit volume of water in unit time at the prevailing kinematic viscosity through a cross section of unit area, measured at right angles to the direction of flow, under a hydraulic gradient of unit change in head over unit length of flow path. Formerly called field coefficient of permeability.

Hydraulic gradient - The change in static head per unit of distance in a given direction. 
Moderately saline water - Water containing 3,000 to $10,000 \mathrm{mg} / \mathrm{L}$ dissolved solids (Winslow and Kister, 1956, p. 5).

National Geodetic Vertical Datum of 1929 (NGVD of 1929) - A geodetic datum derived from a general adjustment of the first-order level nets of both the United States and Canada, formerly called mean sea level.

Potentiometric surface - A surface which represents the static head. As related to an aquifer, it is defined by the levels to which water will rise in tightly cased wells. The water table is a particular potentiometric surface. Slightly saline water - Water containing 1,000 to $3,000 \mathrm{mg} / \mathrm{L}$ dissolved solids (Winslow and Kister, 1956, p. 5).

Specific capacity - The rate of discharge of water from a well divided by the drawdown of water level in the well. It generally is expressed in gallons per minute per foot of drawdown for a specified period after discharge ceases. Specific yield - The quantity of water that an aquifer will yield by gravity $i f$ it is first saturated and then allowed to drain; the ratio expressed in percentage of the volume of water drained to volume of the aquifer drained. Storage coefficient - The volume of water an aquifer releases from or takes into storage per unit of surface area of the aquifer per unit change in the component of head normal to that surface.

Transmissivity - The rate at which water of the prevailing kinematic viscosity is transmitted through a unit width of the aquifer under a unit hydraulic gradient. It is the product of the hydraulic conductivity and the saturated thickness of the aquifer. Formerly called coefficient of transmissibility. Very sal ine water - Water containing 10,000 to $35,000 \mathrm{mg} / \mathrm{L}$ dissolved solids (Winslow and Kister, 1956, p. 5).

Water level; static level or hydrostatic level - In an unconfined aquifer, the distance from the land surface to the water table. In a confined (artesian) aquifer, the level to which the water will rise either above or below land surface.

Water table - The water table is that surface in an unconfined water body at which the pressure is atmospheric. It is defined by the levels at which water stands in wells that penetrate the water body just far enought to hold standing water. In wells which penetrate to greater depths, the water level will stand above or below the water table if an upward or downward component of ground-water flow exists.

Yield - The rate of discharge, commonly expressed as gallons per minute, gallons per day, or gallons per hour. In this report, yields are classified as small, less than $50 \mathrm{gal} / \mathrm{min}$; moderate, 50 to $250 \mathrm{gal} / \mathrm{min}$; and large, more than $250 \mathrm{gal} / \mathrm{min}$. 
GROUND-WATER RESOURCES OF

RUSK COUNTY, TEXAS

By

W. M. Sandeen

\section{ABSTRACT}

Fresh to slightly saline water is available in most parts of Rusk County, which is located in the Piney Woods region of northeast Texas. The Wilcox aquifer, which underlies the entire county, was the source of most of the ground water withdrawn during 1980. Other units capable of yielding fresh ground water are the Carrizo, Queen City, and Sparta aquifers and the Reklaw Formation.

About 5.4 million gallons per day (20,440 cubic meters per day) of ground water was used for all purposes during 1980. Of this amount, about 78 percent was used for public supply, 10 percent for mining, 8 percent for industrial purposes, and 4 percent for rural domestic use. Water levels have declined extensively at the city of Henderson, which used about 38 percent of all ground water consumed in Rusk County.

Generally, the ground water is of acceptable quality. Water in some of the near-surface beds and some of the deeper sands in the Wilcox aquifer may have become mineralized because of oilfield operations. Ground-water contamination by oilfield brines at Henderson 0il Field has been documented. Two separate instances of streamflow contamination at Striker Creek and Henderson 0il Field have been documented.

Moderate amounts of ground water are available for development. The amount that is available perennially is not known, but it is greater than that being withdrawn. Assuming a hydraulic gradient of about 8 feet per mile (1.5 meters per kilometer), at least 12 million gallons per day $(45,420$ cubic meters per day) of fresh ground water is being transmitted through the Wilcox and about 3 million gallons per day $(11,350$ cubic meters per day) through the Carrizo. About 20 million acre-feet $(24,660$ cubic hectometers) of freshwater is available from storage in the Wilcox and about 4 million acre-feet $(4,930$ cubic hectometers) from storage in the Carrizo. Additional amounts of slightly saline water are available from the major aquifers. Smaller but undetermined amounts of fresh ground water are available from the Sparta and Queen City aquifers and from the Reklaw Formation. Properly constructed wells in the Wilcox and Carrizo aquifers can be expected to yield more than 500 gallons per minute (32 liters per second) if the wells are properly spaced. Development of additional resources around the city of Henderson and the Mount Enterprise Fault System should be considered cautiously because of the probability of saltwater encroachment. Ground water in other parts of the county is practically undeveloped. 
Some mineralization of ground water is due to natural causes. Other mineralization of ground water is due to contamination. A program needs to be initiated to determine the extent and cause of mineralization that has taken place in freshwater sands. Water-quality data is needed at Henderson in order to monitor saltwater encroachment. 
Rusk County, located in the Piney Woods region of northeast Texas, is bordered by Gregg and Harrison Counties on the north, Panola and Shelby Counties on the east, Nacogdoches County on the south, and Cherokee and Smith Counties on the west (fig. 1). The city of Henderson, the county seat and largest city in the county, is about $135 \mathrm{miles}(217 \mathrm{~km})$ east of Dallas and about $75 \mathrm{miles}$ (121 km) west of Shreveport, Louisiana. Rusk County has an area of 939 square miles $\left(2,432 \mathrm{~km}^{2}\right)$. Altitude of the land surface ranges from 227 feet $(69 \mathrm{~m})$ near the Sabine River to 709 feet $(216 \mathrm{~m})$ near the town of Mount Enterprise.

\section{Purpose and Scope}

This is a report of a detailed investigation of the ground-water resources of Rusk County begun during 1979 by the U.S. Geological Survey in cooperation with the Texas Department of Water Resources. After about 5 months of initial work, the project was deferred for lack of funds. The project was resumed during 1981, which made it necessary to update the 1979 data including 1981 water levels.

The purpose of the investigation was to determine the occurrence, availability, dependability, quality, and quantity of ground water present in the county. Special emphasis was placed upon describing the quantity and quality of ground water suitable for public supply and industrial use.

The investigation included: Determining the extent of sands containing freshwater; documenting the chemical quality of the water; estimating the quantities of water being withdrawn; determining the effects of withdrawals on ground-water levels; estimating the hydraulic characteristics of the waterbearing sands; rating the area on the basis of ground-water availability; and determining the potential sources of contamination.

\section{Methods of Investigation}

Field data for this report were collected during March through June, 1979, and during March through July, 1981. Data from older reports were included, the earliest of which was written in 1932, shortly after the discovery of East Texas 0il Field. Basic information, including depths of wells, water levels, methods of well construction, type of lift, yield characteristics, and use of water was collected for 365 wells. In addition, water samples were collected for chemical analysis. All relevant information previously collected by the Texas Department of Water Resources and the Geological Survey was used.

Basic data used in describing the hydrologic characteristics and features of the various aquifers in this report are derived from the field inventory of existing water wells, drillers' logs of representative wells, measurement of water levels in these wells, collection and analysis of water samples from the wells, and aquifer tests. The well inventories are compiled in table 1, drillers' logs in table 2, water levels in table 3 , and water-quality analyses in tables $4 \mathrm{a}$ and $4 \mathrm{~b}$ (supplemental information). 


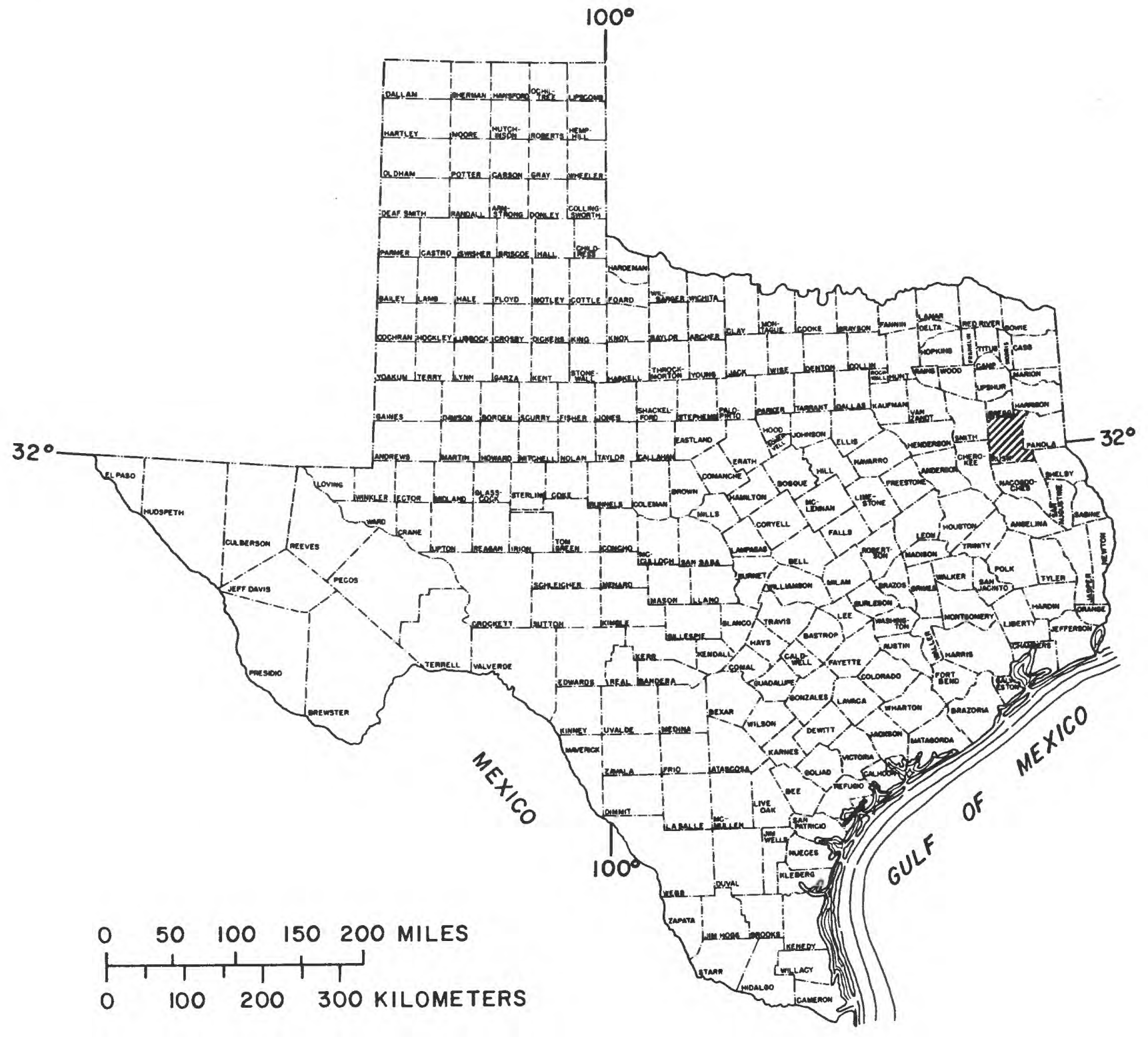

Figure 1.-Location of Rusk County 
Most data relating to the quantity of ground water withdrawn for public supply and industrial uses were obtained from records of the Texas Department of Water Resources. Some quantities were estimated on the basis of the number of users and normal rates of use.

The map of the geologic units is from the Geologic Atlas of Texas, which was prepared by the University of Texas, Bureau of Economic Geology (1965, 1968). Electric logs of oil, gas, and water wells commonly were used for control in preparation of the geologic sections and for maps showing the altitudes of aquifers, the base of fresh and slightly saline water, and approximate thickness of sands containing freshwater. Additional subsurface information was provided by drillers' logs of wells. In some instances, projections of fault blocks from the surface to the subsurface were made to show relationships existing along the Mount Enterprise Fault Zone.

Representative results of aquifer tests from previously published data in adjacent counties were analyzed by the Theis nonequilibrium method as modified by Cooper and Jacob (1946) and the Theis recovery method (Wenzel, 1942). Data relating to secondary recovery, saltwater production, surface casing, and oil production in $0 i 1$ and gas fields were acquired from records of the Railroad Commission of Texas and the East Texas Salt Water Disposal Company.

Altitudes not previously determined were interpolated from available Geological Survey 7-1/2 and 15-minute topographic maps having a contour interval ranging between 10 feet $(3 \mathrm{~m})$ and 20 feet $(6 \mathrm{~m})$ in the study area.

\section{Physiography, Drainage, and Climate}

Rusk County is in the West Gulf Coastal Plain physiographic province (Fenneman, 1939) and a part of the Piney Woods region of East Texas. The most prominent physiographic feature is the Mount Enterprise Fault System, which extends along an east-west axis across the southern part of the county. The system forms a series of hills, some of which attain an altitude in excess of 600 feet $(183 \mathrm{~m})$, extending from due east of Mount Enterprise to near Reklaw, where the system is somewhat offset to the north. The land surface slopes away from these high ridges, generally to the north and to the south, interrupting a regional surface sloping in an easterly and southerly direction. Substantial growths of pine and hardwood occur throughout much of the county.

Springs commonly are found at higher and intermediate altitudes. Streams in the northeastern part of the county drain to the Sabine River whereas those in the southwestern part drain to the Neches River. Striker Creek and Bowles Creek drain into the Striker Creek Lake, Beaver Run and Tiawichi Creek into Lake Cherokee, and Martin Creek into Martin Lake.

Rusk County has a warm, semihumid climate. Annual precipitation at Henderson for 1909-80 ranged from 23 inches (584 mm) during 1963 to 68 inches $(1,727 \mathrm{~mm})$ during 1957 and averaged 38.8 inches $(986 \mathrm{~mm})$ as shown in figure 2 . According to the National Oceanic and Atmospheric Administration, the monthly precipitation at Henderson for 1941-70 ranged from 2.81 inches (71 mm) during July to 5.79 inches $(147 \mathrm{~mm})$ during May and averaged 3.94 inches $(100 \mathrm{~mm})$ as shown in figure 3 . 


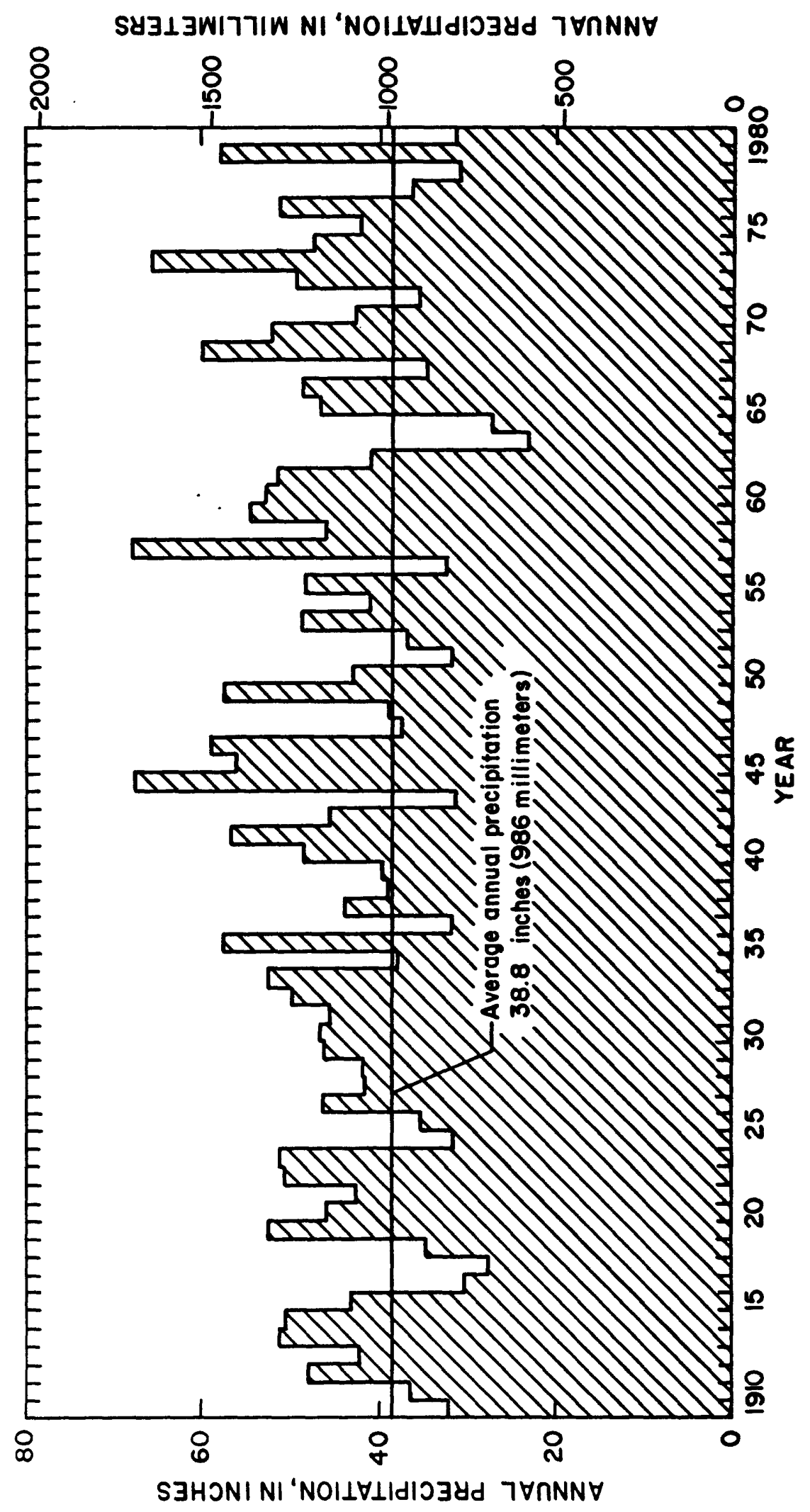



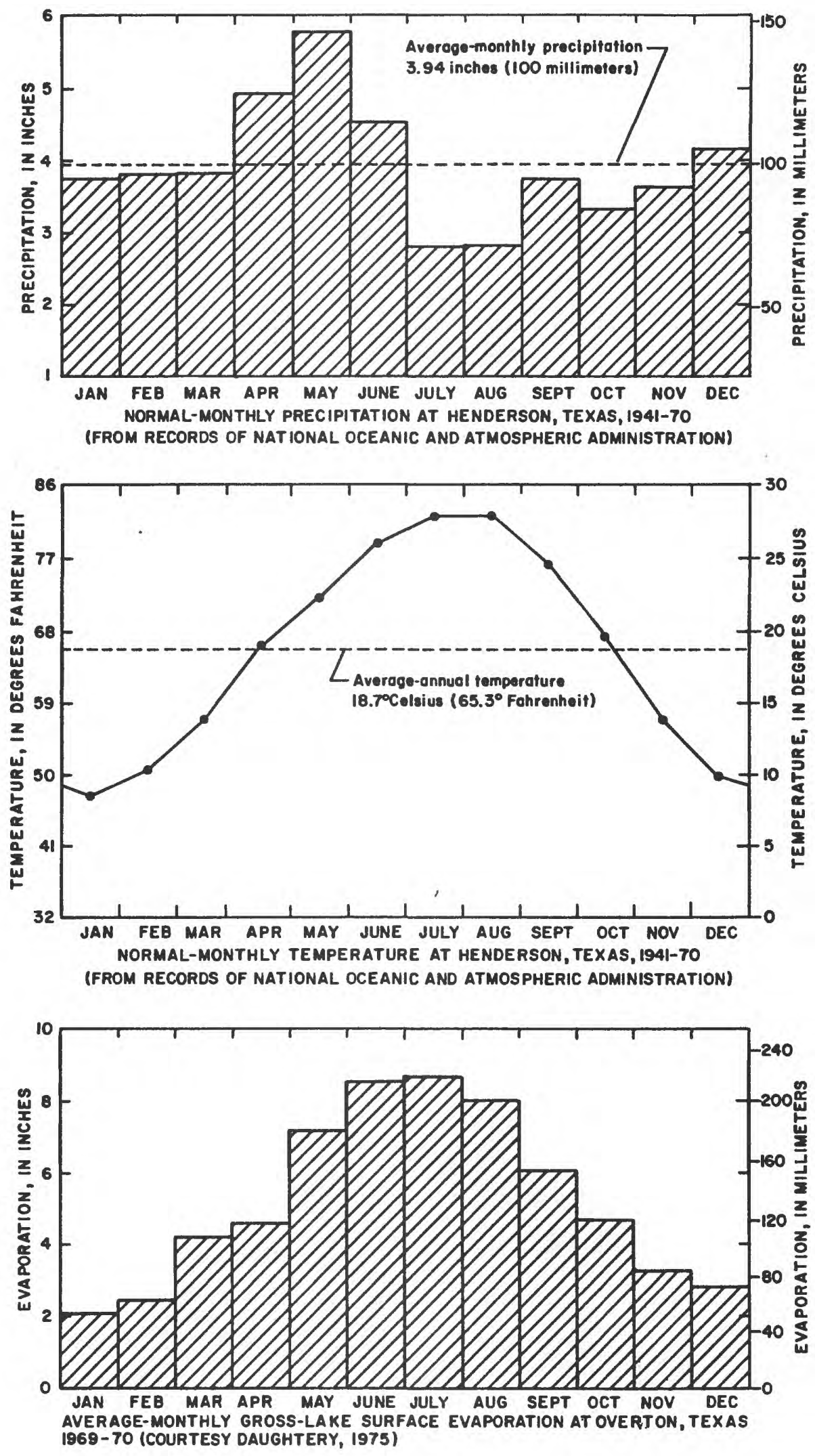
The average-annual temperature at Henderson (fig. 3) is $18.7^{\circ} \mathrm{C}\left(65.3^{\circ} \mathrm{F}\right)$. Dates of the first and last freezes are about November 14 and February 20; the average growing season lasts about 250 days. The average-annual gross-1ake surface evaporation for 1969 and 1970 at Overton was 66.6 inches $(1,692 \mathrm{~mm})$ according to Dougherty (1975).

\section{Economic Development}

During 1980, oil and gas, lignite leasing, lumbering, agriculture, and clay products provided the main sources of income for Rusk County. Until 1930, 1 umbering and agriculture provided the mainstay for the economy of the area. The beginning of the oil and gas industry in the county occurred during 1929 when "Dad" Joiner (fig. 4) started his No. 3 Daisy Bradford well in northwest Rusk County. The well was completed during 1930 as the first discovery well for East Texas 0il Field (Rusk, Gregg, Upshur, and Smith Counties). The location of this field and others are shown in figure 5. Since that time, oil and gas and the processing of petroleum and related products have been the most significant industry.

Completion of the No. 3 Daisy Bradford, however, came at an awkward time, just before the height of the depression. Independents drilled hundreds of wells, many of which were on town lot spacing. So much crude was produced from East Texas that the price of oil fell to 10 cents a barrel. When riots started, Governor Ross Sterling called out the National Guard to preserve order. It also was at this time that he appointed $E$. 0 . Thompson to the Texas Railroad Commission and delegated to him the responsibility of regulating oil and gas production in Texas.

By 1980, East Texas 0il Field had produced over 4.622 billion barrels $\left(734,898,000 \mathrm{~m}^{3}\right)$ of $0 i 1$ and was responsible for making Rusk County rank among the larger oil producing counties in Texas. The field also had produced substantial quantities of saltwater. According to a 1961 oilfield-brine disposal inventory prepared by the Texas Water Commission and Texas Water Pollution Control Board (1963), 156.7 million barrels $\left(24,915,300 \mathrm{~m}^{3}\right)$ of saltwater were produced that year. This was an average of 0.427 million barrels $\left(67,890 \mathrm{~m}^{3}\right)$ a day, 99 percent of which was disposed of through injection wells.

\section{Population}

Rusk County has a population of 41,382 according to the Bureau of Census (1980). Henderson, the county seat, has a population of 11,473. Populations of other towns are: Overton, 2,430; Tatum, 1,614; New London, 942; and Mount Enterprise, 485. The 1980 census also shows that 2,543 of the people living in Kilgore (Gregg and Rusk Counties) reside in Rusk County.

\section{Previous Investigations}

Deussen (1914) mentioned the existence of several springs and water wells in his study of the southeastern part of the Texas Coastal Plain including more than 20 Texas counties. Turner (1932) compiled a report on ground water in East Texas 0il Field that covered parts of Gregg, Rusk, Smith, and Upshur 


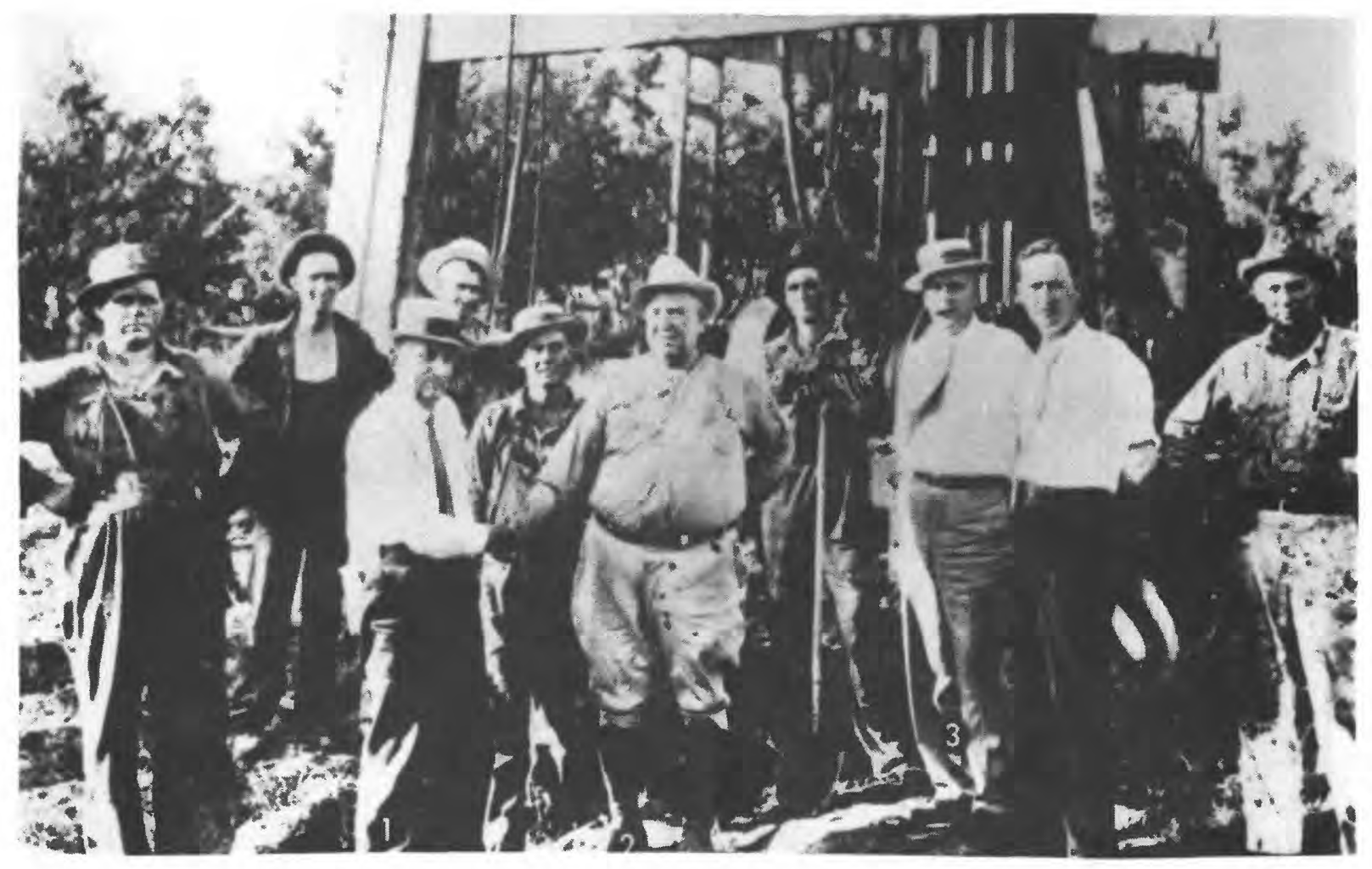

C. M. (Dad) Joiner (1), Dr. Lloyd (2), H. L. Hunt (3), and dilling crew

Flgure 4.-C.M. (Dad) Joiner, Dr. Lloyd, H. L. Hunt,and drilling crew of No. 3 Dalsy Bradford, discovery well of East Texas Oll Fleld (1030). Photo courtesy of YOUTH SPEAKS 


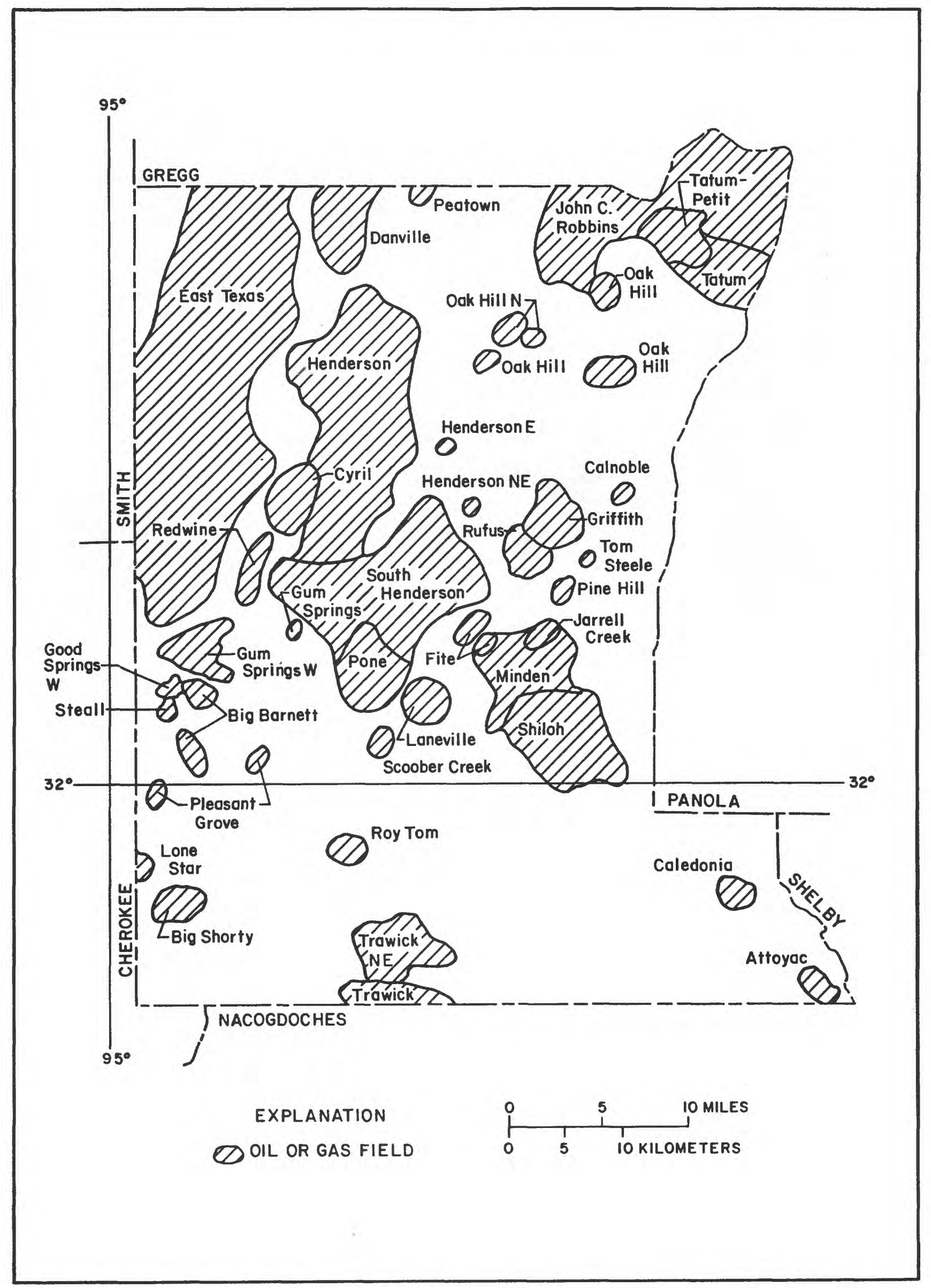

Figure 5.-Location of significant oil and gas fields

$-10-$ 
Counties. He concluded that saltwater contamination of the freshwater-bearing zones probably had not occurred at that time. Turner suggested that the possibility of bacteriological contamination of ground water existed and recommended that all "abandoned oil wells that yield a flow of saltwater should be plugged." He also recommended that special attention be given to setting "surface casing." Lyle (1937) presented a comprehensive inventory of about 406 wells, drillers' logs, and water analyses and included a location map of Rusk County. During this same period, a number of test holes were drilled using Works Progress Administration (WPA) labor. Follett (1943) augmented Lyle's data by publishing an inventory of about 160 old and new wells in the northwestern part of Rusk County.

Baker, Peckham, Dillard, and Souders (1963) made a reconnaissance of the ground-water resources of the Neches River basin that included Rusk County. In another report, Baker, Dillard, Souders, and Peckham (1963) made a reconnaissance of the ground-water resources of the Sabine River that included a part of Rusk County. Between 1937 and 1940, water levels were measured in a number of shallow observation wells near Henderson but were previously unpub7 ished. About 1972, the Texas Department of Water Resources (TDWR), formerly the Texas Water Development Board (TWDB), established a group of observation wells in Rusk County. Water levels were measured periodically and water samples from representative wells were analyzed for chemical constituents.

Reports discussing the ground-water resources of counties adjacent to Rusk County include: Smith County (Dillard, 1963); Gregg and Upshur Counties (Broom, 1969); Angelina and Nacogdoches Counties (W. F. Guyton and Associates, 1970); and Anderson, Cherokee, Freestone, and Henderson Counties (W. F. Guyton and Associates, 1972).

In addition to the ground-water investigations, a reconnaissance of water quality of surface water in the Neches River basin was made by Hughes and Leifeste (1967). Their study includes data on the Striker Creek drainage basin, which is nearly centered along the county line of the west side of Rusk County. Approximately two-thirds of the watershed is in East Texas 0il Field.

\section{Well-Numbering System}

The local well-numbering system used in this report is the system adopted by the Texas Department of Water Resources for use throughout the State. Under this system, each 1-degree quadrangle in the State is given a number consisting of two digits. These are the first two digits in the well number. Each 1degree quadrangle is divided into 7-1/2-minute quadrangles that are given twodigit numbers from 01 to 64. These are the third and fourth digits of the well number. Each 7-1/2-minute quadrangle is subdivided into 2-1/2-minute quadrangles and given single-digit numbers from 1 to 9 . This is the fifth digit of the well number. Each well within a 2-1/2-minute quadrangle is given a twodigit number in the order in which it was inventoried. These are the last two digits of the well number. The well location on a map is shown by listing only the last three digits of the well number adjacent to the well location. The second two digits are shown in the northwest corner of each 7-1/2-minute quadrangle, and the first two digits are shown by the large double-line numbers. 
In addition to the seven-digit well number, a two-letter prefix is used to identify the county. The prefixes for Rusk and adjacent counties are as follows:

\begin{tabular}{lclc}
\hline \multicolumn{1}{c}{ County } & Prefix & County & Prefix \\
\cline { 2 - 4 } Cherokee & & & UL \\
Gregg & DJ & Panola & WR \\
Harrison & LK & Rusk & XB \\
Nacogdoches & TX & Shelby & XH \\
\hline
\end{tabular}

For example, well WR-35-50-801, which supplies water for the city of Henderson, is in Rusk County (WR) in the 1-degree quadrangle (35), in the 7-1/2minute quadrangle (50), in the 2-1/2-minute quadrangle (8), and was the first well (01) inventoried in that 2-1/2-minute quadrangle (fig. 6). Well numbers used by Lyle (1937) and Follett (1943) and the corresponding numbers used in this report are given in table 5 ("old number"). The location of wells, springs, and selected test holes used in this report are shown in figure 7 .

The Geological Survey's national site identification system uses the 1 atitude-longitude coordinate system. The combination of the 6-digit latitude number, the 7-digit longitude number, and a 2-digit sequence number forms a 15-digit site identification number. For example, the first site at latitude $32^{\circ} 15^{\prime} 42^{\prime \prime}$ and longitude $94^{\circ} 34^{\prime} 23^{\prime \prime}$ gives a site-identification number of 321542094342301. A cross reference between the local and national systems for the wells in this report are given in table 5 .

\section{Acknowledgments}

The author expresses his appreciation to the many land owners, well owners, and industrial and municipal officials for their cooperation and for allowing access to their properties. Particular appreciation is expressed to Jack Cook, Water Superintendent, City of Henderson; Bob Lomax, Manager, El derville Water Supply Corporation; John Seifert, W. F. Guyton and Associates; Jack Waldron, Layne-Texas Company; Jackie Murray; Rick Hornsby, Exxon Coal USA, Inc.; and Casey $\mathrm{Cl}$ awson, Henderson $\mathrm{Cl}$ ay Products.

\section{GEOLOGIC FRAMEWORK AND PHYSICAL CHARACTERISTICS OF THE GEOLOGIC UNITS}

Rusk county is in an area affected by several regional structural features--the Sabine Uplift, Mount Enterprise Fault System, and East Texas Embayment (fig. 8). Geologic units, ranging in age from Paleocene and Eocene (Wilcox Group) through the Holocene (alluvium), crop out at the surface as shown in figure 9. Beds of the Carrizo Sand, which crop out over about a third of the county, are slightly more extensive than those of the older Wilcox Group. A description of the geologic units and their water-bearing characteristics is given in table 6 . Stratigraphic and structural relationships in the subsurface are shown on the geologic sections (fig. 10-12). 


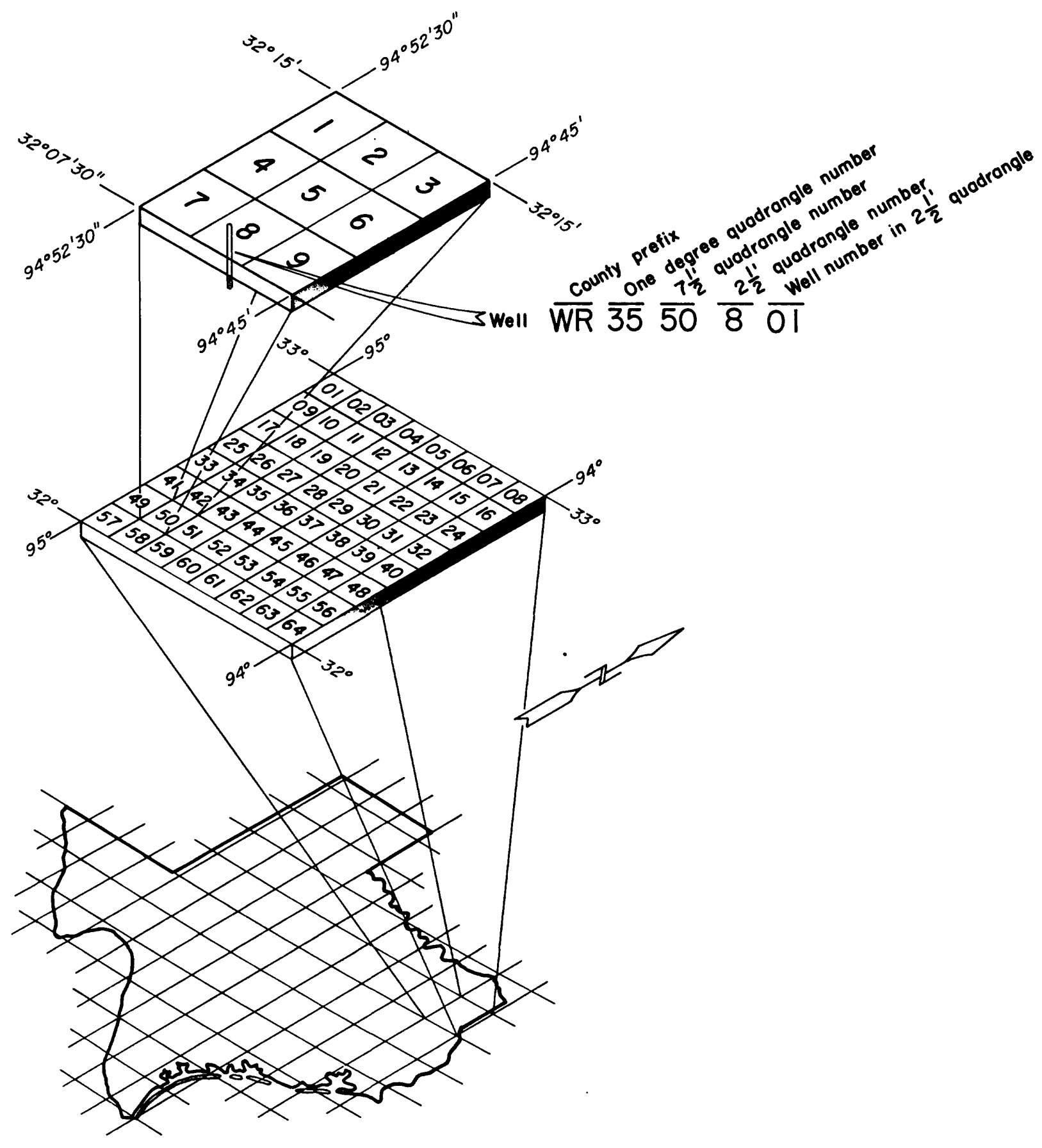




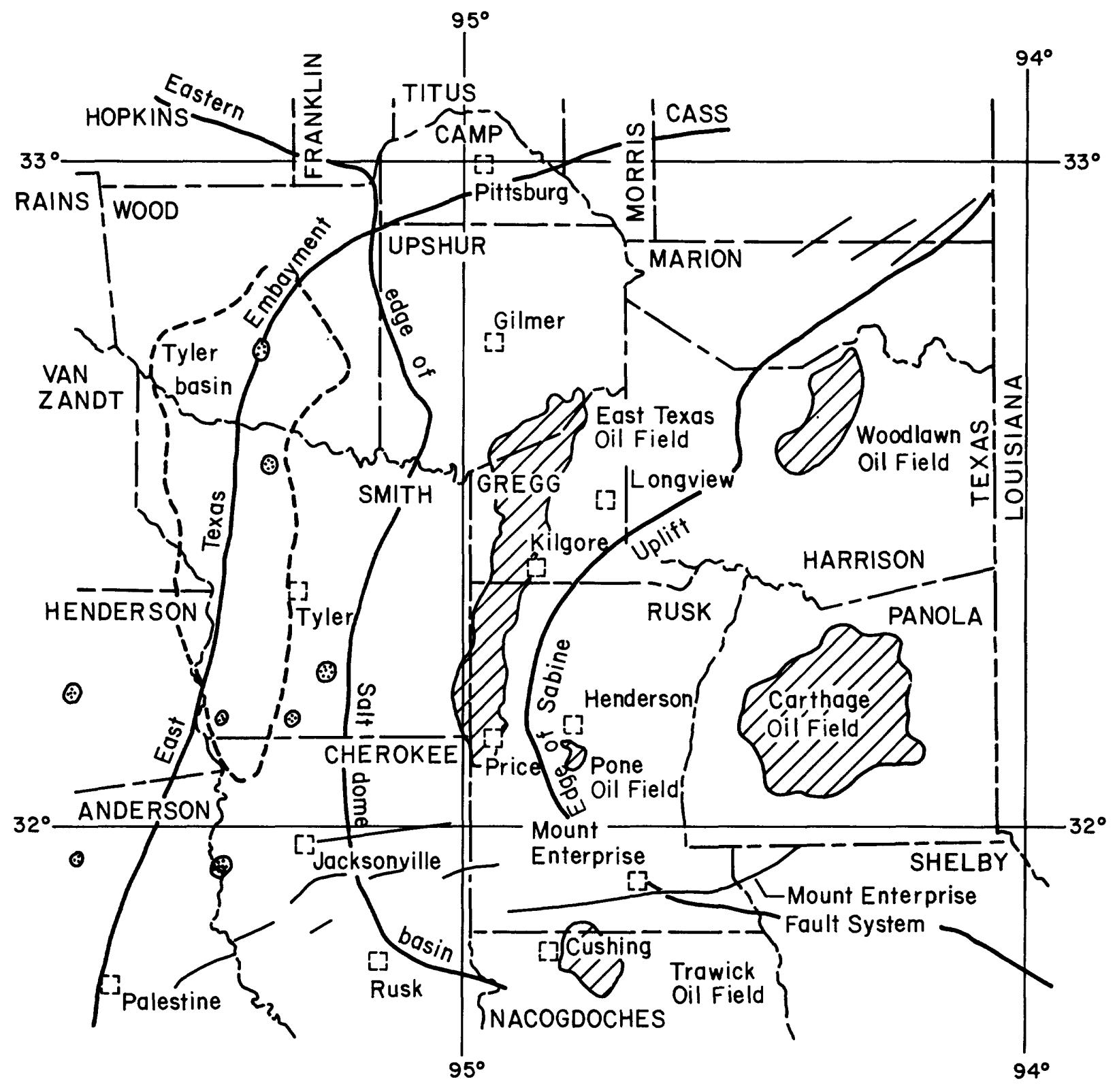

EXPLANATION

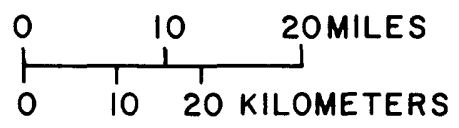

(8.8) SALT DOME FAULT 
Table 5.--Cross reference of well numbers in Rusk County

\begin{tabular}{|c|c|c|c|c|c|c|c|c|}
\hline $\begin{array}{c}\text { Odd } \\
\text { number }\end{array}$ & $\begin{array}{c}\text { New } \\
\text { number }\end{array}$ & $\begin{array}{c}\text { Site } \\
\text { identification }\end{array}$ & $\begin{array}{c}\text { old } \\
\text { number }\end{array}$ & $\begin{array}{c}\text { New } \\
\text { Number }\end{array}$ & $\begin{array}{c}\text { Site } \\
\text { identification }\end{array}$ & $\begin{array}{c}\text { od } \\
\text { number }\end{array}$ & $\begin{array}{c}\text { New } \\
\text { number }\end{array}$ & $\begin{array}{c}\text { Site } \\
\text { identification }\end{array}$ \\
\hline $\begin{array}{r}4 \\
7 \\
14 \\
16 \\
17\end{array}$ & $\begin{array}{l}\text { WR-35-41-101 } \\
\text { WR-35-41-401 } \\
\text { WR-35-41-708 } \\
\text { WR-35-41-705 } \\
\text { WR-35-41-707 }\end{array}$ & $\begin{array}{l}322038094581701 \\
321859094585701 \\
321633094581101 \\
321632094583702 \\
321631094583401\end{array}$ & $\begin{array}{l}248 \\
251 \\
255 \\
260 \\
289\end{array}$ & $\begin{array}{l}\text { WR-35-50-703 } \\
\text { WR-35-50-701 } \\
\text { WR-35-50-702 } \\
\text { WR-35-50-403 } \\
\text { WR-35-49-509 }\end{array}$ & $\begin{array}{l}320910094505001 \\
320855094522401 \\
320925094491801 \\
321120094414601 \\
321143094552501\end{array}$ & $\begin{array}{l}567 \\
571 \\
575 \\
576 \\
577\end{array}$ & $\begin{array}{l}\text { WR-37-10-101 } \\
\text { WR-37-02-803 } \\
\text { WR-37-02-401 } \\
\text { WR-37-02-501 } \\
\text { WR-37-02-601 }\end{array}$ & $\begin{array}{l}315101094503301 \\
315234094493701 \\
315510094501401 \\
315707094492401 \\
315718094471501\end{array}$ \\
\hline $\begin{array}{l}22 a \\
31 \\
31 a \\
32 \\
40\end{array}$ & $\begin{array}{l}\text { WR-35-41-706 } \\
\text { WR-35-41-510 } \\
\text { WR-35-41-509 } \\
\text { WR-35-41-505 } \\
\text { WR-35-41-202 }\end{array}$ & $\begin{array}{l}321524094584601 \\
321751094564301 \\
321752094565101 \\
321844094565301 \\
322100094555601\end{array}$ & $\begin{array}{l}294 \\
299 a \\
310 \\
313 \\
315\end{array}$ & $\begin{array}{l}\text { WR-35-49-304 } \\
\text { WR-35-41-810 } \\
\text { WR-35-49-101 } \\
\text { WR-35-49-103 } \\
\text { WR-35-49-102 }\end{array}$ & $\begin{array}{l}321352094540301 \\
321501094560301 \\
321448094583201 \\
321408094582001 \\
321413094573001\end{array}$ & $\begin{array}{l}578 \\
579 \\
583 \\
585 \\
588\end{array}$ & $\begin{array}{l}\text { WR-37-02-602 } \\
\text { WR-37-02-604 } \\
\text { WR-37-03-701 } \\
\text { WR-37-11-203 } \\
\text { WR-37-02-603 }\end{array}$ & $\begin{array}{l}315712094472401 \\
315520094472901 \\
315255094444401 \\
325204094422801 \\
315710094450401\end{array}$ \\
\hline $\begin{array}{l}47 a \\
50 \\
62 \\
70 \\
75\end{array}$ & $\begin{array}{l}\text { WR-35-41-308 } \\
\text { WR-35-41-508 } \\
\text { WR-35-41-902 } \\
\text { WR-35-41-903 } \\
\text { WR-35-41-904 }\end{array}$ & $\begin{array}{l}322000094540001 \\
321939094552101 \\
321625094540701 \\
321539094163601 \\
321609094531401\end{array}$ & $\begin{array}{l}316 a \\
327 \\
336 a \\
343 \\
367\end{array}$ & $\begin{array}{l}\text { WR-35-49-205 } \\
\text { WR-35-49-303 } \\
\text { WR-35-49-510 } \\
\text { WR-35-57-803 } \\
\text { WR-35-57-504 }\end{array}$ & $\begin{array}{l}321415094562501 \\
321338094545901 \\
321146094564401 \\
320115094564601 \\
320302094563901\end{array}$ & $\begin{array}{l}589 \\
590 \\
593 \\
594 \\
596\end{array}$ & $\begin{array}{l}\text { WR-37-03-401 } \\
\text { WR-37-03-402 } \\
\text { WR-37-03-503 } \\
\text { WR-37-03-504 } \\
\text { WR-37-03-901 }\end{array}$ & $\begin{array}{l}315714094440001 \\
315620094432001 \\
315520094413401 \\
315507094410201 \\
325430094394101\end{array}$ \\
\hline $\begin{array}{l}80 \\
82 \\
88 \\
90 \\
92\end{array}$ & $\begin{array}{l}\text { WR-35-42-402 } \\
\text { WR-35-42-403 } \\
\text { WR-35-41-201 } \\
\text { WR-35-42-601 } \\
\text { WR-35-42-501 }\end{array}$ & $\begin{array}{l}321750094500201 \\
321941094500401 \\
322125094554001 \\
321952094472901 \\
321811094475601\end{array}$ & $\begin{array}{l}369 \\
375 \\
384 \\
393 \\
398\end{array}$ & $\begin{array}{l}\text { WR-35-57-601 } \\
\text { WR-35-57-301 } \\
\text { WR-35-49-807 } \\
\text { WR-35-49-604 } \\
\text { WR-35-49-902 }\end{array}$ & $\begin{array}{l}320310094532501 \\
320647094541701 \\
320910094553701 \\
321022094523901 \\
320852094525301\end{array}$ & $\begin{array}{l}598 \\
607 \\
608 \\
609 \\
619\end{array}$ & $\begin{array}{l}\text { WR-37-11-301 } \\
\text { WR-37-04-402 } \\
\text { WR-37-04-201 } \\
\text { WR-37-04-301 } \\
\text { WR-37-12-201 }\end{array}$ & $\begin{array}{l}325051094385501 \\
325708094352201 \\
325740094333501 \\
325802094315501 \\
315055094332501\end{array}$ \\
\hline $\begin{array}{l}100 \\
103 \\
108 \\
111 \\
114\end{array}$ & $\begin{array}{l}\text { WR-35-42-904 } \\
\text { WR-35-42-602 } \\
\text { WR-35-43-401 } \\
\text { WR-35-42-303 } \\
\text { WR-35-42-302 }\end{array}$ & $\begin{array}{l}321703094454301 \\
321757094453701 \\
321826094442801 \\
322147094452901 \\
322036094461501\end{array}$ & $\begin{array}{l}402 \\
409 \\
415 \\
416 \\
420\end{array}$ & $\begin{array}{l}\text { WR-35-59-402 } \\
\text { WR-35-50-805 } \\
\text { WR-35-50-910 } \\
\text { WR-35-50-901 } \\
\text { WR-35-50-911 }\end{array}$ & $\begin{array}{l}320410094441801 \\
320701094484401 \\
320908094440201 \\
320852094470701 \\
320816094461501\end{array}$ & $\begin{array}{l}621 \\
629 \\
631 \\
634 \\
642\end{array}$ & $\begin{array}{l}\text { WR-37-12-303 } \\
\text { WR-35-41-304 } \\
\text { WR-35-41-309 } \\
\text { WR-35-41-307 } \\
\text { WR-35-41-507 }\end{array}$ & $\begin{array}{l}325054094304501 \\
322140094542201 \\
322113094542901 \\
322020094534301 \\
321951094553401\end{array}$ \\
\hline $\begin{array}{l}126 \\
130 \\
132 \\
136 \\
140\end{array}$ & $\begin{array}{l}\text { WR-35-43-801 } \\
\text { WR-35-43-901 } \\
\text { WR-35-44-702 } \\
\text { WR-35-44-403 } \\
\text { WR-35-44-503 }\end{array}$ & $\begin{array}{l}321651094411101 \\
321628094382001 \\
321718094370501 \\
321856094361501 \\
321954094344801\end{array}$ & $\begin{array}{l}423 \\
426 \\
427 \\
429 \\
433\end{array}$ & $\begin{array}{l}\text { WR-35-58-302 } \\
\text { WR-35-59-501 } \\
\text { WR-35-59-603 } \\
\text { WR-35-59-302 } \\
\text { WR-35-59-203 }\end{array}$ & $\begin{array}{l}320522094451801 \\
320440094415501 \\
320414094392101 \\
320510094392601 \\
320654094404201\end{array}$ & $\begin{array}{l}652 \\
653 \\
654 \\
656 \\
658\end{array}$ & $\begin{array}{l}\text { WR-35-41-703 } \\
\text { WR-35-41-803 } \\
\text { WR-35-41-802 } \\
\text { WR-35-49-203 } \\
\text { WR-35-49-201 }\end{array}$ & $\begin{array}{l}321632094583701 \\
321616094554301 \\
321617094554201 \\
321457094555801 \\
321427094562101\end{array}$ \\
\hline $\begin{array}{l}146 \\
151 \\
152 \\
165 \\
168\end{array}$ & $\begin{array}{l}\text { WR-35-44-302 } \\
\text { WR-35-44-604 } \\
\text { WR-35-44-605 } \\
\text { WR-35-51-903 } \\
\text { WR-35-52-702 }\end{array}$ & $\begin{array}{l}322015094302501 \\
321904094322501 \\
321836094316801 \\
320844094381101 \\
320946094372401\end{array}$ & $\begin{array}{l}434 \\
505 \\
507 \\
519 \\
524\end{array}$ & $\begin{array}{l}\text { WR-35-51-902 } \\
\text { WR-35-59-904 } \\
\text { WR-35-60-701 } \\
\text { WR-35-59-701 } \\
\text { WR-37-03-101 }\end{array}$ & $\begin{array}{l}320911093383601 \\
320222094383201 \\
320138094362001 \\
320224094433501 \\
315950094443101\end{array}$ & $\begin{array}{l}661 \\
669 \\
671 \\
682 \\
684\end{array}$ & $\begin{array}{l}\text { WR-35-41-704 } \\
\text { WR-35-49-208 } \\
\text { WR-35-49-209 } \\
\text { WR-35-49-503 } \\
\text { WR-35-49-504 }\end{array}$ & $\begin{array}{l}321532094580001 \\
321321094550101 \\
321309094551501 \\
321217094561801 \\
321222094571101\end{array}$ \\
\hline $\begin{array}{l}175 \\
176 \\
177 \\
179 \\
179 a\end{array}$ & $\begin{array}{l}\text { WR-35-51-603 } \\
\text { WR-35-51-503 } \\
\text { WR-35-51-802 } \\
\text { WR-35-50-913 } \\
\text { WR-35-50-912 }\end{array}$ & $\begin{array}{l}321055094394701 \\
321044094411402 \\
320908094421202 \\
320930094450201 \\
320928094450801\end{array}$ & $\begin{array}{l}528 \\
532 \\
534 \\
535 \\
536\end{array}$ & $\begin{array}{l}\text { WR-35-58-801 } \\
\text { WR-37-02-102 } \\
\text { WR-37-02-206 } \\
\text { WR-37-02-101 } \\
\text { WR-35-58-702 }\end{array}$ & $\begin{array}{l}320200094480501 \\
315756094502701 \\
315915094484901 \\
315929094502301 \\
320154094510101\end{array}$ & $\begin{array}{l}694 \\
697 \\
698 \\
704 \\
711\end{array}$ & $\begin{array}{l}\text { WR-35-49-508 } \\
\text { WR-35-49-507 } \\
\text { WR-35-49-603 } \\
\text { WR-35-49-506 } \\
\text { WR-35-49-50 5 }\end{array}$ & $\begin{array}{l}321126094562201 \\
321048094550901 \\
321045094533401 \\
321049094561501 \\
321036094570001\end{array}$ \\
\hline $\begin{array}{l}183 \\
185 \\
187 \\
191 \\
206\end{array}$ & $\begin{array}{l}\text { WR-35-51-102 } \\
\text { WR-35-50-303 } \\
\text { WR-35-59-203 } \\
\text { WR-35-50-205 } \\
\text { WR-35-50-601 }\end{array}$ & $\begin{array}{l}321413094424001 \\
321319094454701 \\
320654094404201 \\
321309094474601 \\
321007094470401\end{array}$ & $\begin{array}{l}538 \\
547 \\
548 \\
549 \\
551\end{array}$ & $\begin{array}{l}\text { WR-35-58-701 } \\
\text { WR-37-01-103 } \\
\text { WR-37-01-202 } \\
\text { WR-37-01-203 } \\
\text { WR-37-01-401 }\end{array}$ & $\begin{array}{l}320154094515801 \\
315949094583701 \\
315959094561701 \\
315754094551501 \\
315728094584301\end{array}$ & $\begin{array}{l}722 \\
730 \\
736 \\
742 \\
752\end{array}$ & $\begin{array}{l}\text { WR-35-49-402 } \\
\text { WR-35-49-403 } \\
\text { WR-35-49-808 } \\
\text { WR-35-49-801 } \\
\text { WR-35-49-702 }\end{array}$ & $\begin{array}{l}321105094575301 \\
321004094574801 \\
320954094553801 \\
320809094562901 \\
320858094581801\end{array}$ \\
\hline $\begin{array}{l}218 \\
224 \\
225 \\
230 \\
240 a\end{array}$ & $\begin{array}{l}\text { WR-35-50-404 } \\
\text { WR-35-50-101 } \\
\text { WR-35-50-102 } \\
\text { WR-35-50-103 } \\
\text { WR-35-50-402 }\end{array}$ & $\begin{array}{l}321032094502001 \\
321452094512801 \\
321339094505901 \\
321253094515801 \\
321117094504901\end{array}$ & $\begin{array}{l}558 \\
559 \\
563 \\
564 \\
565\end{array}$ & $\begin{array}{l}\text { WR-37-01-701 } \\
\text { WR-37-01-803 } \\
\text { WR-37-01-601 } \\
\text { WR-37-01-901 } \\
\text { WR-37-09-201 }\end{array}$ & $\begin{array}{l}315438094574201 \\
315402094561201 \\
315513094533201 \\
315322094542301 \\
315114094553801\end{array}$ & $\begin{array}{l}758 \\
760 \\
761 \\
762\end{array}$ & $\begin{array}{l}\text { WR-35-50-902 } \\
\text { WR-35-50-803 } \\
\text { WR-35-50-804 } \\
\text { WR-35-50-903 }\end{array}$ & $\begin{array}{l}320908094470201 \\
320851094480901 \\
320833094473401 \\
320902094470501\end{array}$ \\
\hline
\end{tabular}




\begin{tabular}{|c|c|c|c|c|c|c|c|c|c|}
\hline 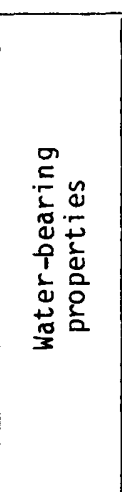 & 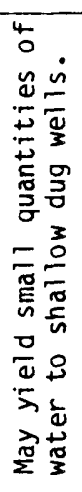 & 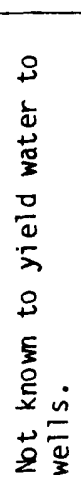 & 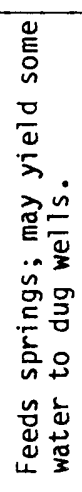 & 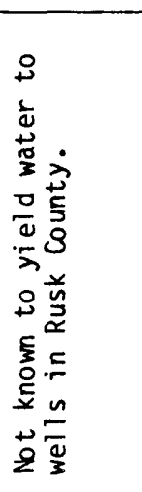 & 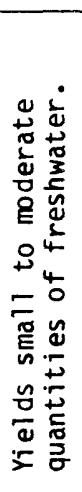 & 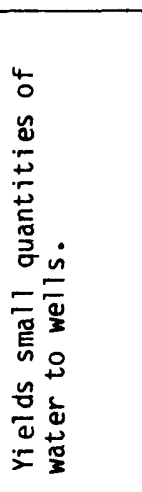 & 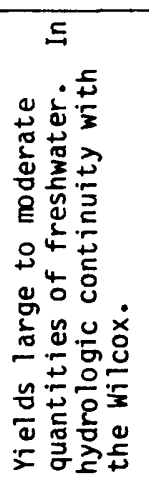 & 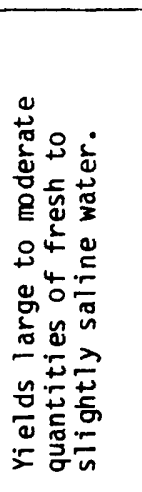 & 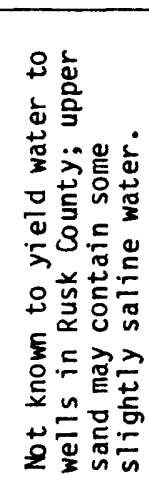 \\
\hline $\begin{array}{l}\frac{5}{0} \\
\frac{1}{n} \\
\frac{8}{5} \\
3\end{array}$ & 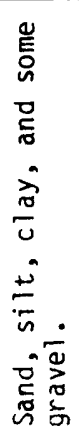 & 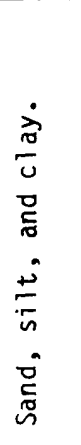 & 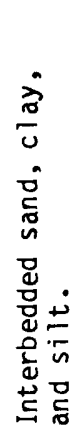 & 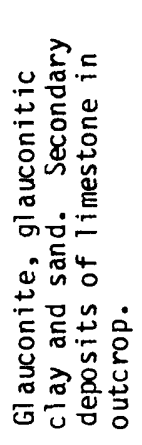 & 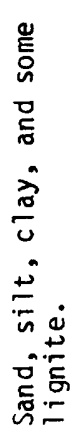 & 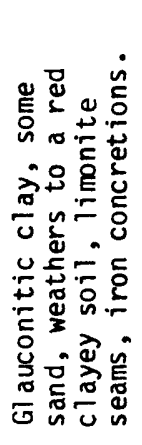 & 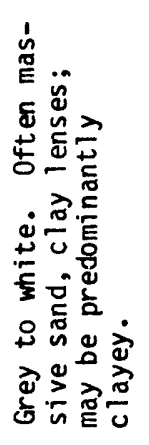 & 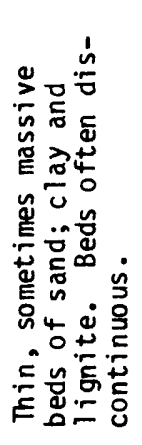 & 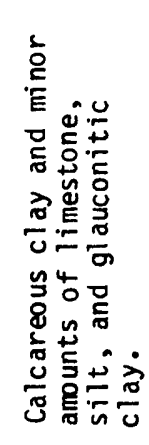 \\
\hline 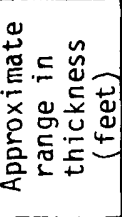 & $\stackrel{m}{\stackrel{m}{d}}$ & 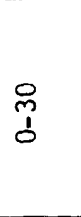 & $\begin{array}{l}8 \\
\stackrel{1}{1} \\
\end{array}$ & $\begin{array}{l}0 \\
0 \\
0 \\
0\end{array}$ & 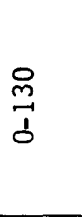 & 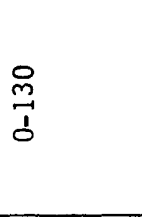 & $\stackrel{\stackrel{m}{m}}{\vec{b}}$ & 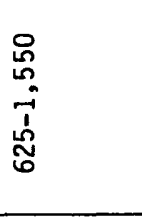 & 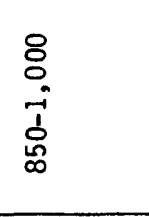 \\
\hline$\stackrel{\overrightarrow{5}}{\overrightarrow{5}}$ & $\frac{\frac{5}{3}}{\frac{3}{3}}$ & 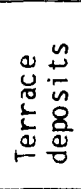 & 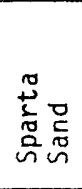 & 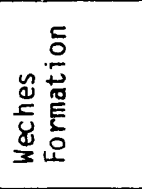 & 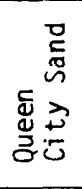 & 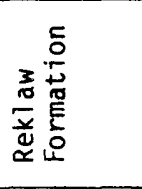 & 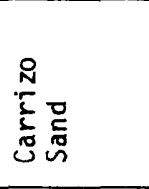 & & \\
\hline $\begin{array}{l}\text { a } \\
\text { : } \\
0\end{array}$ & & & & & 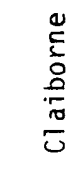 & & & 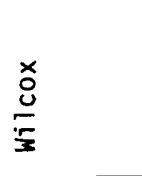 & $\begin{array}{l}\text { ते } \\
\frac{\pi}{\tilde{z}} \\
\frac{\pi}{\Sigma}\end{array}$ \\
\hline$\frac{\infty}{\infty}$ & 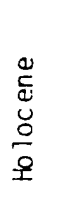 & 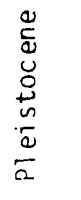 & & & 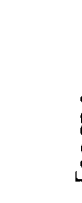 & & & & 俈 \\
\hline 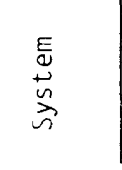 & & & & & & 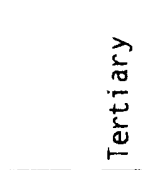 & & & \\
\hline
\end{tabular}


The Sabine Uplift (fig. 8) is a structurally complicated area in northeast Texas and northwest Louisiana. The western boundary extends into Rusk County. Sands, red beds, and shales of the Cretaceous Woodbine Formation were deposited over this uplift and later eroded. East Texas 0il Field, a stratigraphic trap, produces oil from the Woodbine at a depth of about 3,650 feet $(1,112 \mathrm{~m})$. About $20-25$ miles $(32-40 \mathrm{~km})$ west of the eastern edge of East Texas Oil Field lies the nadir of the East Texas Embayment, into which the Woodbine thickens. Such features were at times instrumental in controlling the deposition of the Wilcox.

The Mount Enterprise Fault System trends east-west across southern Rusk County. The queen City Sand, Weches Formation, and Sparta Sand are preserved in the downthrown side of this system. Eaton (1956, p. 83) notes that there was moderate movement along this system in Midway time, considerable movement during $\mathrm{Cl}$ aiborne time, and a marked movement during post-Claiborne time. An earthquake of 7 on the Richter scale was reported at Rusk (Cherokee County), during 1891 but is questioned by von Hake (1977). Collins, Hobday, and Kreitler (1980, p. 16) suggest that the event may have been seismic. They use releveling data to conclude that the system has been active during the past 30 years.

Further information on the geologic relationships existing in this area is available from Sellards, Adkins, and Plummer (1932) and from Kreitler and others (1980). For a generalized regional appraisal relating to the structural and depositional altitude of the Wilcox Group, the reader is referred to Jones and others (1976).

\section{Mi dway Group}

The Midway Group, mostly marine in origin, is composed chiefly of calcareous clay, which locally may contain thin stringers of limestone and glauconitic sand. In places, the unit is silty and slightly sandy in the uppermost part of the section.

The altitude of the top of the Midway, which coincides with the base of the Wilcox Group (fig. 13), ranges from about 300 feet $(91 \mathrm{~m}$ ) below sea level in the northeastern part of the county to about 1,600 feet $(488 \mathrm{~m})$ below sea level in the southwestern part of the county. In the northern part of the county, the beds dip at a rate of about $30 \mathrm{ft} / \mathrm{mi}(5.7 \mathrm{~m} / \mathrm{km})$ to the west. In the southern part of the county, they dip about $50 \mathrm{ft} / \mathrm{mi}(9.5 \mathrm{~m} / \mathrm{km})$ to the southwest.

The Midway Group is not known to yield water to wells in the area. Nevertheless, the unit is hydrologically significant because the Midway Group forms the basal confining unit for the overlying Wilcox Group. There is also a sand body about 30 feet $(9 \mathrm{~m})$ thick within the uppermost $200 \mathrm{ft}(61 \mathrm{~m})$ that may contain small amounts of slightly saline water. In a few instances the base of slightly saline water has been picked at the base of this sand bed from electric logs. 

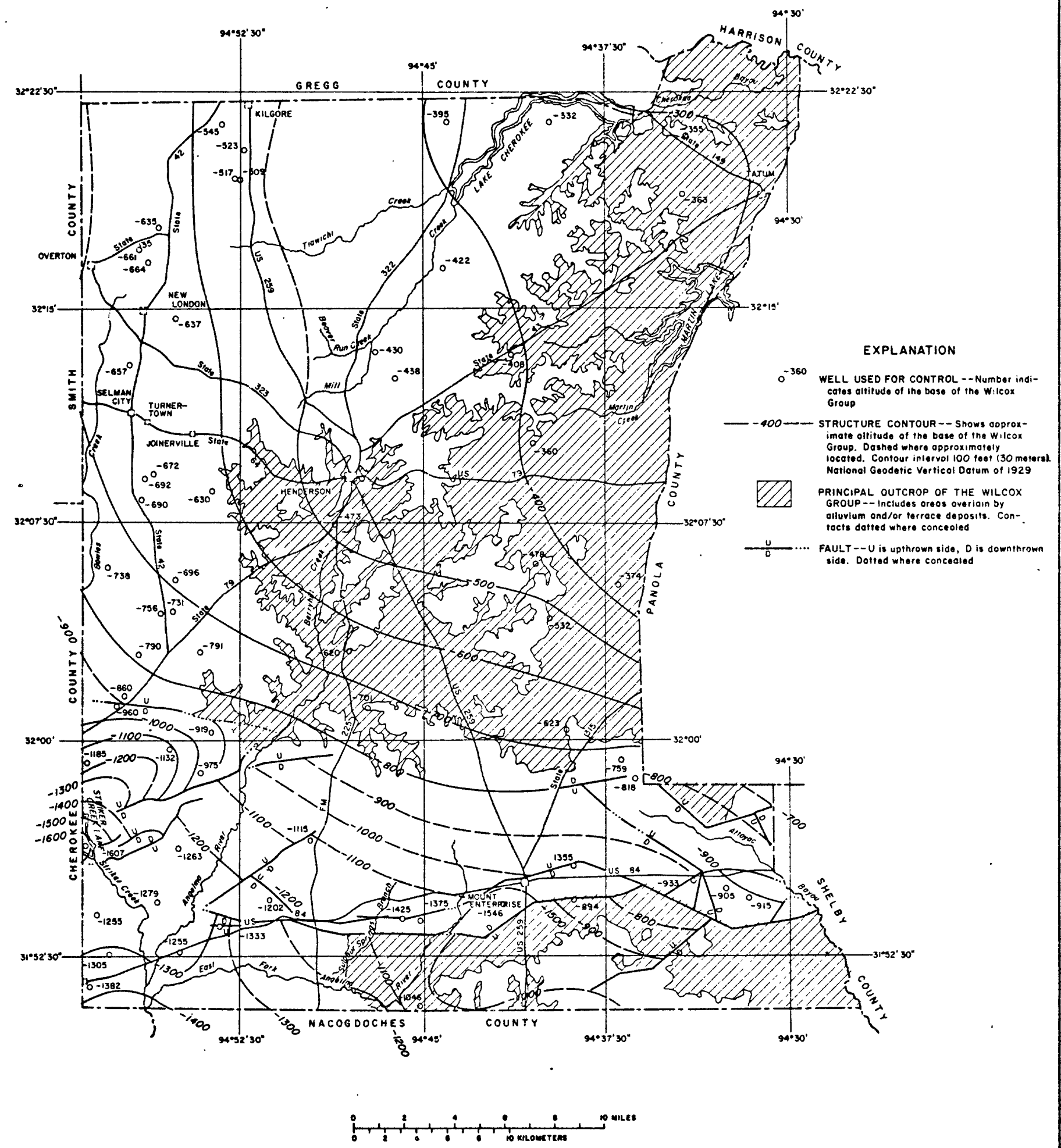


\section{Wi lcox Group}

The Wilcox Group is exposed on the surface in northeastern and eastcentral Rusk County and comformably overlies the Midway. It consists mainly of thin, but sometimes massive beds of sand, silt, and clay with minor amounts of lignite and secondary deposits of limonite. Typically, the sands are gray, fine grained and silty. Often the beds are fluvial and deltaic in nature. Due to facies changes, individual beds often are difficult to correlate from well to well. However, some beds of coarse grained sand attain a thickness of nearly 200 feet or $61 \mathrm{~m}$ (well WR-35-59-901). Other beds cannot be correlated from well to well as is clearly shown in the geologic sections (fig. 10-12).

The altitude of the top of the Wilcox Group is depicted in figure 14. Except where interrupted by the Mount Enterprise Fault System, these beds dip at the rate of about $30 \mathrm{ft} / \mathrm{mi}(5.7 \mathrm{~m} / \mathrm{km})$ in a direction away from the Sabine Uplift.

\section{Carrizo Sand}

The Carrizo Sand uncomformably overlies the Wilcox Group and crops out more extensively than any other geologic unit in the county. It attains a maximum thickness of about 135 feet $(41 \mathrm{~m})$. Surface exposures usually are reddish in color and often cross bedded. In the subsurface the Carrizo is a massive, fine- to medium-grained white quartz sand. It also contains a few clay lenses, but rarely is predominantly clay. In electrical logs, the Carrizo is distinguished from the overlying Reklaw and underlying Wilcox by a markedly higher resistivity. In places, however, the contacts are difficult to pick. As does the Wilcox Group, the Carrizo Sand dips away from the Sabine Uplift into the East Texas Embayment at a rate of about $30 \mathrm{ft} / \mathrm{mi}(5.7 \mathrm{~m} / \mathrm{km})$ except where interrupted by the Mount Enterprise Fault System.

\section{Reklaw Formation}

The Reklaw Formation conformably overlies the Carrizo Sand. The Reklaw attains a maximum thickness of about 130 feet $(40 \mathrm{~m})$ and is exposed primarily in the northern part of the county and north of the Mount Enterprise Fault system. The formation consists of glauconitic clay and minor amounts of sand and lignite. The basal part of the Reklaw contains a silty, glauconitic fine grained quartz sand that is often difficult to distinguish from the underlying Carrizo using electric logs. In the outcrop, the Reklaw forms a red clay soil characterized by limonite seams and iron concretions, easily distinguished from the underlying gray sandy soil of the Carrizo.

\section{Queen City Sand}

The Queen City Sand, which overlies the Reklaw Formation, consists mostly of alternating beds of very fine to fine grained quartz sand and clay. The Queen City Sand crops out over an area of about 100 square miles $\left(259 \mathrm{~km}^{2}\right)$ and attains a maximum thickness of about 130 feet $(40 \mathrm{~m})$ where overlain by the Weches Formation. The maximum thickness occurs mainly in the downdropped blocks associated with the Mount Enterprise Fault System. Elsewhere, the 


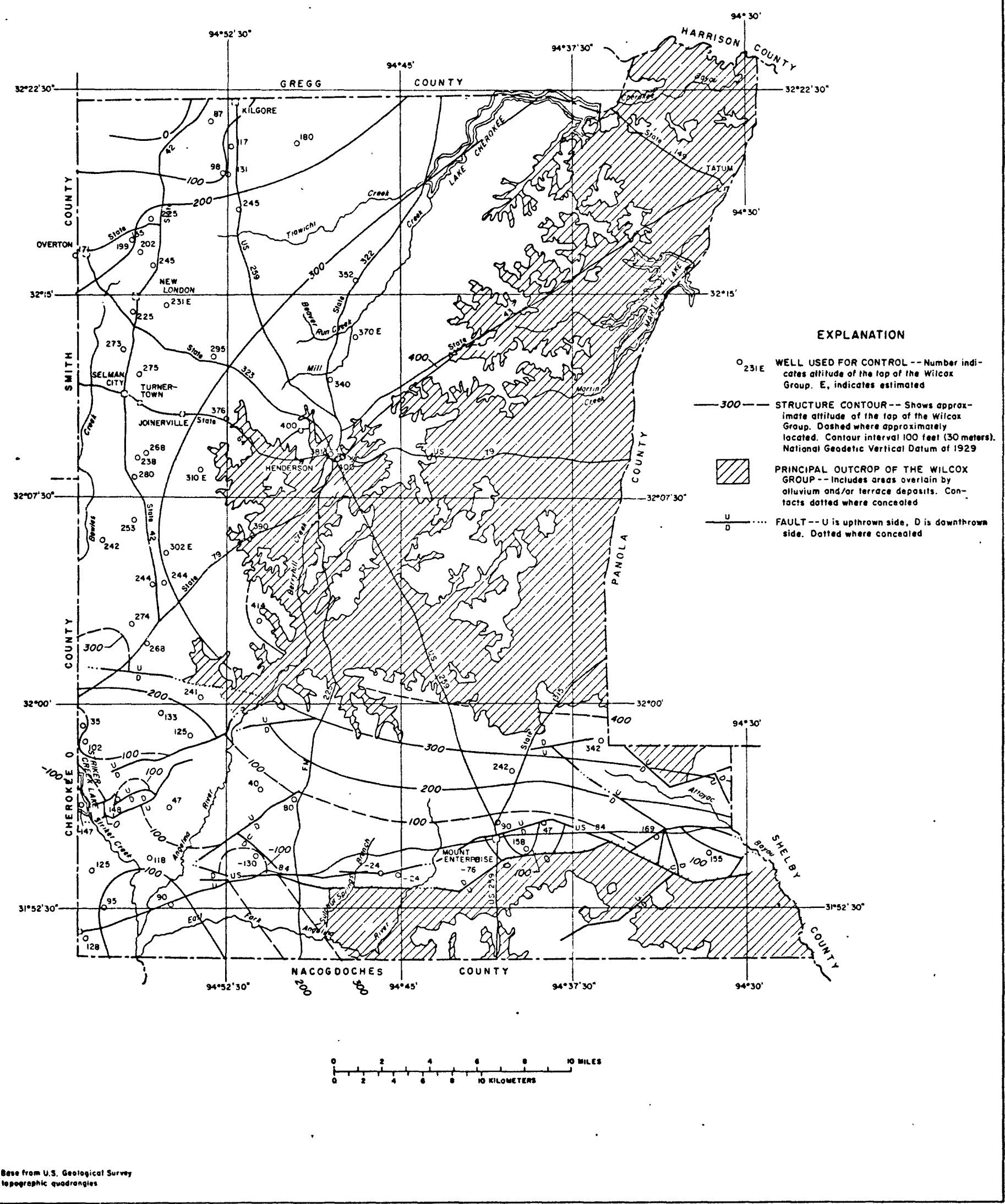

Figure 14-Approximate allitude of the top of the Wilcox Group 
Queen City is eroded and relatively thin. There is not enough control to adequately map the Queen City Sand.

\section{Weches Formation}

The Weches Formation, consisting of interbedded glauconitic clay and sand, crops out as scattered outliers in the Mount Enterprise Fault System area. The Weches attains a maximum thickness of about 50 feet $(15 \mathrm{~m})$, but is not known to yield water to wells in Rusk County.

\section{Sparta Sand}

The Sparta Sand consists of fine sand and sandy clay and silt, attains a thickness of about 100 feet $(30 \mathrm{~m})$, and is exposed only in the area of the Mount Enterprise Fault System. Numerous springs issue from the contact of the Sparta with the underlying Weches. The formation yields small quantities of freshwater to wells in adjacent counties. Springs issuing from the Sparta yield moderate quantities of ground water to the base flow of small streams in southern Rusk County.

\section{Terrace Deposits and Alluvium}

Terrace deposits, probably of Pleistocene age, are present at several places along the Sabine and Angelina Rivers. These beds are remnants of a formerly more extensive surface that has been largely removed by erosion. The terrace deposits are in continuity with the underlying Eocene beds but are considered hydrologically insignificant.

Al luvium is present in and around the flood plains of the principal streams (fig. 9). These deposits, consisting of fine sand, silt, clay, and possibly gravel, have an estimated maximum thickness of about 35 feet $(10 \mathrm{~m})$. Al luvial deposits are capable of yielding at least small amounts of water to wells. At least one well in Rusk County is completed in the alluvium.

\section{HYDROLOGIC UNITS}

In order to simplify the discussion of hydrology in the area, the following previously described geologic units are designated as aquifers in Rusk County: Wilcox Group, Carrizo Sand, Queen City Sand, and Sparta Sand. The other geologic units are designated as confining beds and are: Midway Group, Reklaw Formation, and Weches Formation. A number of dug wells tap the thin basal sand of the Reklaw.

\section{Wilcox Aquifer}

Broom (1969) noted that the Carrizo and Wilcox have similar hydrologic properties and are in hydrologic continuity in Gregg county. Consequently, he considered them to function as a single aquifer. W. F. Guyton and Associates 
(1970, 1972) considered the two aquifers to be separate units in Cherokee and Nacogdoches Counties. In this report, the Carrizo and Wilcox are treated as two distinct aquifers.

The Wilcox aquifer is present throughout Rusk County and is the most significant hydrologic unit. Substantial withdrawals occur from the middle and lower sands at Henderson and in the area of East Texas 0il Field. Many of the upper sands in the Wilcox are thin, fine grained and silty. By contrast, the lower beds are sometimes massive and coarse grained. Often individual beds are discontinuous.

The quality of water in the Wilcox varies both vertically and laterally from fresh to slightly saline. In rare instances, the water may be moderately saline. In places, the shallower sands may not necessarily contain the best quality water.

The thickness of freshwater-bearing sands in the Wilcox is shown in figure 15. The thickness of sands containing freshwater are based on the interpretation of electric logs. The thickness ranges from about 170 feet $(52 \mathrm{~m})$ to about 400 feet $(122 \mathrm{~m})$. The altitude of the freshwater is shown in figure $16 \mathrm{a}$ and the base of the slightly saline water is shown in figure $16 \mathrm{~b}$.

\section{Carrizo Aquifer}

Another significant water-bearing unit is the Carrizo aquifer, which is present in about 70 percent of the county. In places, however, the Carrizo sands may be interbedded with clay as shown in figure 17, which shows ground water seeping from the Carrizo sands at the Ross clay pit of Henderson Clay Products north of the city of Henderson.

The Carrizo aquifer has an average sand thickness of about 80 feet $(24 \mathrm{~m})$ in the subsurface and 50 feet $(15 \mathrm{~m})$ in the outcrop area. However, a sand thickness map was not constructed because data were inadequate.

\section{Other Aqui fers}

Only a few small-capacity wells draw water from the Queen City aquifer because of its near surface occurrence and small aerial extent. Except for a few isolated exposures in the northwestern part of Rusk County, the Queen City is present only in downdropped blocks associated with the Mount Enterprise Fault System. The Sparta is present only in the area along the Mount Enterprise Fault System. The Sparta is not an important aquifer in Rusk County. Both the Queen City and Sparta feed numerous small springs in Rusk County.

GROUND-WATER HYDROLOGY

Source and Occurrence

Precipitation is the source of all fresh ground water. Most precipitation on the land surface runs off, is consumed by evaporation, or is stored in the soil, later to be evaporated or transpired. A part of the water infiltrates through the pores of the soil and subsoil to the zone of saturation by the 


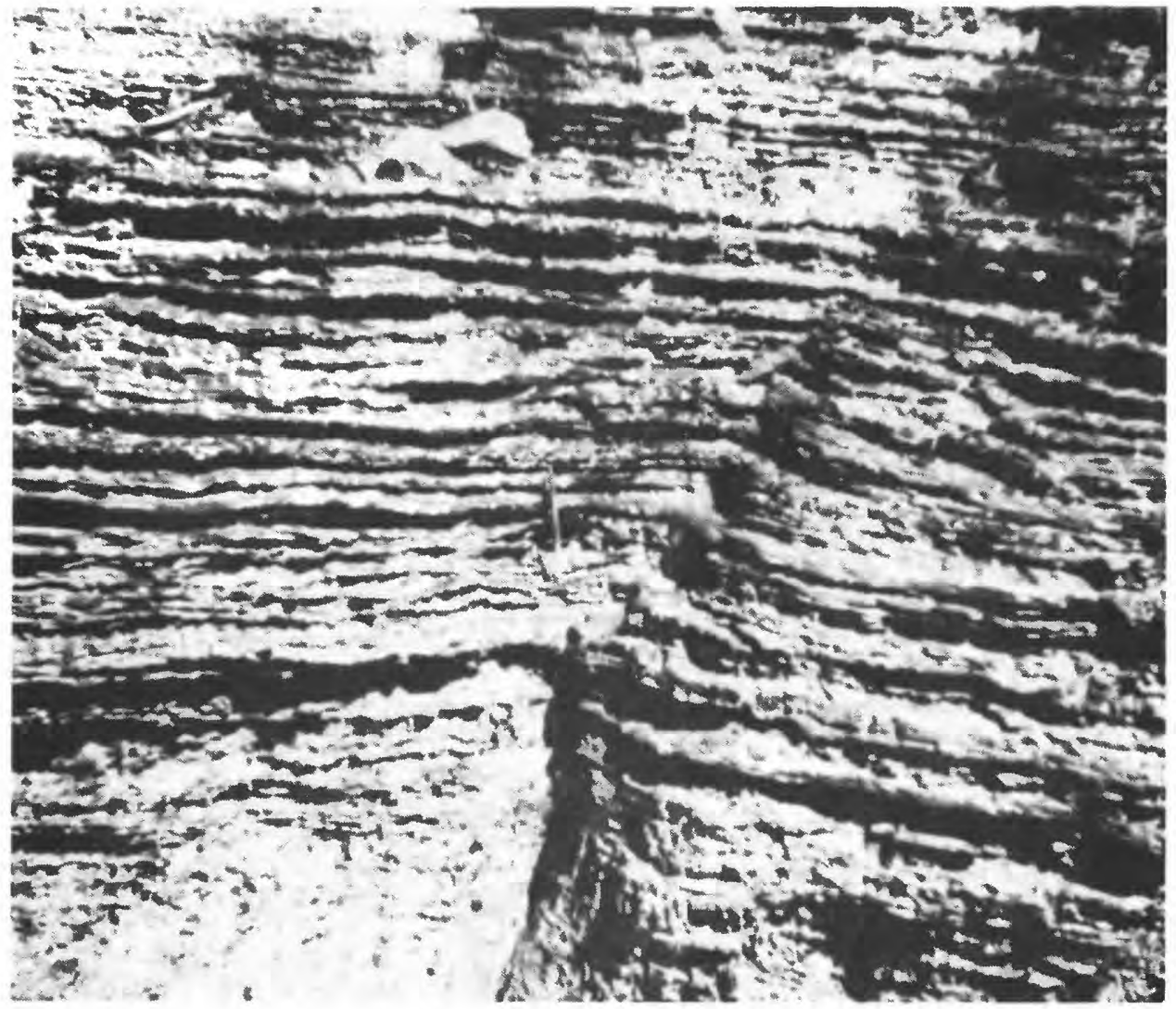

Figure 17.-Ground water seeping from sand layers in the Carrizo aquifer at the Ross clay pit north of the city of Henderson 
forces of gravity and molecular attraction. The zone of saturation is the zone below the water table where the interstices are filled with fluid.

Ground water in the area occurs under water-table and artesian conditions. Under water-table conditions the water is unconfined. When tapped by a well, the unconfined water does not rise above the zone of saturation in the aquifer. Under artesian conditions, the water is confined. When tapped by a well, the confined water rises, due to hydrostatic pressure, above the level at which it is first encountered.

Fresh ground water occurs throughout Rusk County and often in at least several water-bearing sands. The most prolific water-producing zones are the artesian sands of the Wilcox, which are developed for municipal and industrial purposes. All significant withdrawals are from the artesian part of the Carrizo and Wilcox aquifers. Less productive shallow wells that tap the first saturated sand below the land surface are often used for stock and domestic purposes. Water in these beds usually occurs under water-table conditions at a depth of less than 50 feet $(15 \mathrm{~m})$ below land surface. Detailed information on individual wells is given in table 1 .

Recharge, Movement, and Discharge of Ground Water

Recharge, the addition of water to an aquifer by natural or artificial processes, occurs mainly from the infiltration of rainfall into the outcrop. Recharge also may occur by percolation of water from streams and ponded areas. There is a large potential for recharge in Rusk County because the Wilcox and Carrizo crop out in about 60 percent of the area. Although the actual rate of recharge is not known, it probably is less than 1 inch $(25.4 \mathrm{~mm})$ per year.

Ground water moves slowly through the aquifers under the force of gravity from areas of recharge to areas of discharge. The movement under water-table conditions is lateral to discharge areas which, under natural conditions, are topographically lower than the recharge area. The movement under artesian conditions is toward areas of lower pressure head, normally downdip in the aquifer. Water then moves vertically upward into the lower pressured shallow material. Natural discharge also may occur through a seep or spring; artificial discharge may occur through a well. The rate of movement in the aquifers, either laterally or vertically, is dependent on the hydraulic gradient and conductivity of the material. Rates of movement probably are a few hundred feet per year.

The direction of movement in Rusk County in the water-table parts of the aquifers generally is toward the streams. The direction of movement in the artesian parts of the principal aquifers, the Carrizo and Wilcox, is from the outcrop toward the southeast and locally, toward the cones of depression at Henderson, East Texas $0 i l$ Field, and Tatum as shown in the potentiometricsurface map for the Wilcox (fig. 18).

\section{Hydraulic Characteristics of the Aquifers}

The importance of an aquifer as a source of water depends upon "its ability to store and transmit water" according to Ferris and others (1962, p. 70 ). 
These characteristics are expressed in terms of storage coefficient and transmissivity.

No aquifer tests were conducted in Rusk County because of a lack of controlled conditions. Aquifer tests, however, have been performed using wells completed in the Wilcox, Carrizo, and Queen City aquifers in Cherokee County (W. F. Guyton and Associates, 1972), Gregg County (Broom, 1969), and Nacogdoches county (W. F. Guyton and Associates, 1970). The test data were analyzed either by the Theis nonequilibrium method (Theis, 1935) or the modified Theis recovery method (Wenzel, 1942, p. 95). The results are given in table 7.

To estimate the expected range of transmissivities of the Wilcox and Carrizo aquifers in Rusk county, the following assumptions were made:

1. The hydraulic conductivities of the sands in the three adjacent counties (table 7) are representative of the sands in these same aquifers in Rusk county;

2. The sands opposite the screen are similar to the unscreened sands; and

3. The thickness of sands containing freshwater ranges from about 100 to 370 feet ( 30 to $113 \mathrm{~m}$ ) for the Wilcox aquifer.

Based on these assumptions, the transmissivities of the Wilcox aquifer would range from $270-13,500 \mathrm{ft}^{2} / \mathrm{d}\left(25-1,720 \mathrm{~m}^{2} / \mathrm{d}\right)$; and based on a maximum sand thickness of 100 feet in the Carrizo aquifer, the estimated maximum transmissivity is $6,400 \mathrm{ft}^{2} / \mathrm{d}\left(595 \mathrm{~m}^{2} / \mathrm{d}\right)$.

Downdip from the outcrops where the Wilcox and Carrizo aquifers are under artesian conditions, the storage coefficients range from about 0.00006 to 0.0007 , as indicated in table 7 . Al though no data are available for the area, the storage coefficients for the aquifers under water-table conditions would be expected to range from 0.1 to 0.2

The transmissivities and storage coefficients must be known to predict the drawdown of water levels caused by pumping a well or group of wells. The theoretical relationship of drawdown to transmissivity and distance is shown in figure 19. Calculations of drawdown are made on the basis of a group of wells pumping $1 \mathrm{Mgal} / \mathrm{d}\left(3,785 \mathrm{~m}^{3} / \mathrm{d}\right)$ continuously for 1 year from an extensive aquifer.

The relationship of drawdown to time and distance caused by a well or group of wells pumping $1 \mathrm{Mgal} / \mathrm{d}(3,785 \mathrm{~m} / \mathrm{d})$ from an artesian aquifer of infinite extent having a storage coefficient of 0.0001 and a transmissivity of $10,000 \mathrm{ft}^{2} / \mathrm{d}\left(930 \mathrm{~m}^{2} / \mathrm{d}\right)$ is shown in figure 20 . The rate of drawdown decreases with time, but the water level declines indefinitely until a source of recharge is intercepted to offset the withdrawal and establish equilibrium in the aquifer. Because the drawdown is directly proportional to the rate of withdrawal, the drawdown for other than $1 \mathrm{Mgal} / \mathrm{d}\left(3,785 \mathrm{~m}^{3} / \mathrm{d}\right)$ can be determined by multi plying the drawdown value shown in figure 20 by the proper multiple or fraction of $1,000,000$.

Note that figures 19 and 20 show that the drawdown caused by the pumping well is greatest near the well and decreases as distance from the pumping well increases. This is the practical reason for properly spacing wells; mutual interference is decreased and consequently, pumping costs are reduced. 


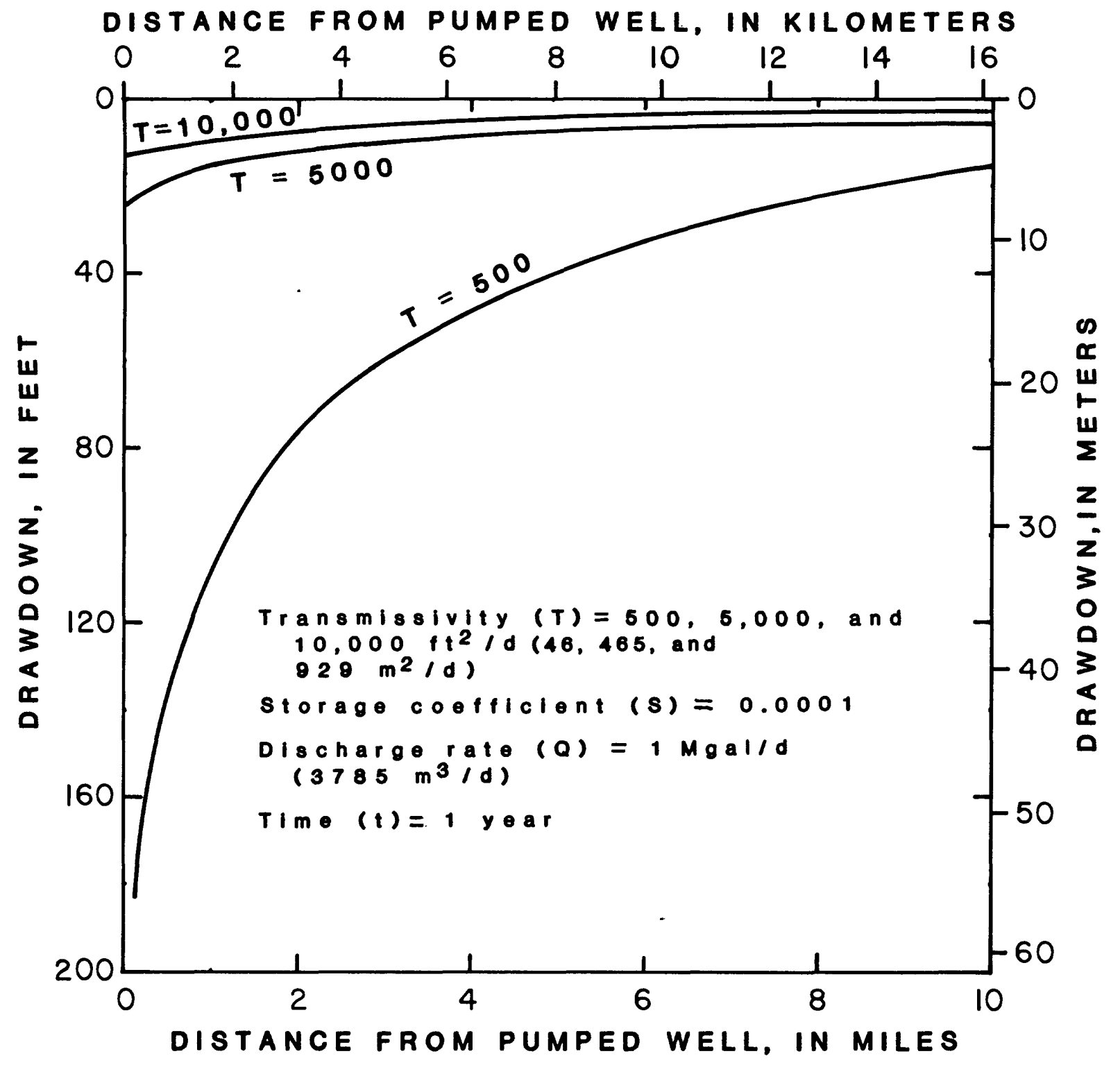

Figure 19.-Relationship of drawdown to transmissivity and distance 


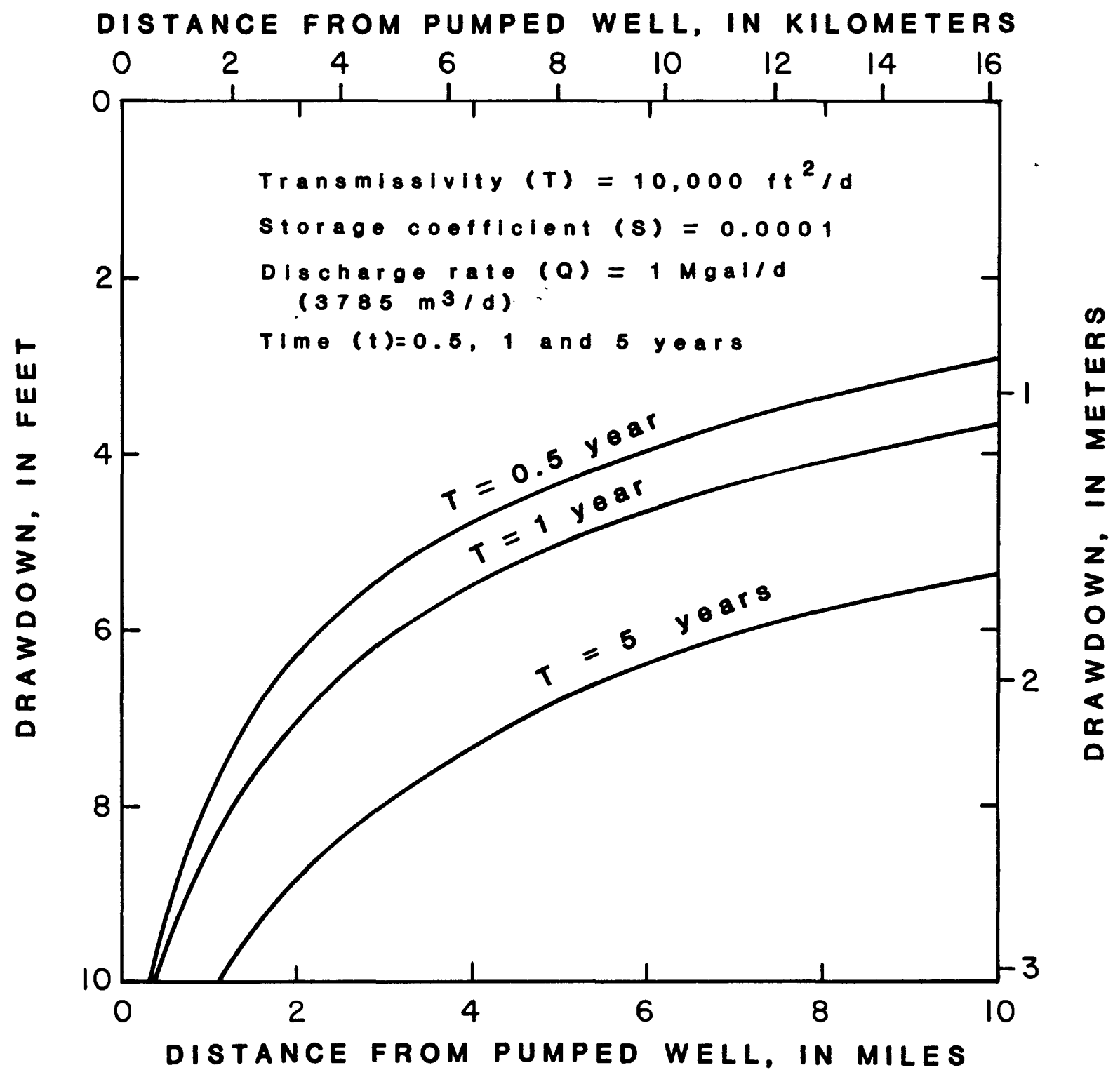

Figure 20.-Relationship of drawdown to time and distance as a result of pumping under artesian conditions 
Table 7.--Results of aquifer tests in Cherokee, Gregg, and Nacogdoches Counties $1 /$

County prefixes: DJ - Cherokee; KU - Gregg; TX - Nacogdoches

\begin{tabular}{|c|c|c|c|c|c|c|}
\hline Well & $\begin{array}{l}\text { Sand thick- } \\
\text { ness of } \\
\text { pumped well } \\
\text { (feet) }\end{array}$ & $\begin{array}{l}\text { Discharge } \\
\text { (gallons } \\
\text { per } \\
\text { minute) } \\
\end{array}$ & $\begin{array}{l}\text { Specific capac- } \\
\text { ity (gallons per } \\
\text { minute per foot } \\
\text { (of drawdown) }\end{array}$ & $\begin{array}{c}\text { Hydraulic } \\
\text { conductivity } \\
\text { (feet per } \\
\text { day) }\end{array}$ & $\begin{array}{c}\text { Storage } \\
\text { coefficient }\end{array}$ & Remarks \\
\hline \multicolumn{7}{|c|}{ Carrizo aquifer } \\
\hline DJ $-37-01-401$ & 75 & 343 & 5.4 & 19.4 & -- & Recovered for 24 hours. \\
\hline 402 & 60 & 350 & 5.4 & 25.5 & -- & Do. \\
\hline & 75 & 350 & -- & 22 & 0.0001 & $\begin{array}{l}\text { Drawdown of observation } \\
\text { well DJ-37-01-401. }\end{array}$ \\
\hline $09-101$ & $\underline{2} / 52$ & 43 & 4.5 & 28.4 & -- & Recovered for 2 hours. \\
\hline $33-202$ & $2 / 70$ & 102 & 1.2 & 63.8 & -- & Do. \\
\hline $38-06-603$ & 80 & 692 & 13.1 & 31.0 & -- & Do. \\
\hline 604 & 90 & 621 & 10.3 & 18.9 & -- & Recovered for 12 hours. \\
\hline $15-102$ & $\underline{2} / 36$ & 36 & 2.1 & 15.7 & -- & Recovered for 2 hours. \\
\hline 502 & 101 & 473 & 7.1 & 20.6 & -- & Recovered for 24.5 hours. \\
\hline DJ-38-32-903 & \multicolumn{5}{|c|}{ Queen City aquifer } & Recovered for 2 hours. \\
\hline$K U-35-26-705$ & 64 & -- & $\frac{\text { Carrizo-Wi] }}{--}$ & $\frac{\text { cox aqui fer }}{11.4}$ & .00006 & $\begin{array}{l}\text { Drawdown of observation } \\
\text { well. }\end{array}$ \\
\hline 706 & 105 & 300 & 2.8 & 5.7 & -- & Drawdown of pumped well. \\
\hline 708 & 75 & 100 & -- & 5.5 & -- & Recovered for 5 months. \\
\hline DJ $-34-64-402$ & 90 & 63 & $6.1^{\text {Wilcox }}$ & $\frac{\text { aqui fer }}{19.4}$ & -- & Recovered for 2 hours. \\
\hline $37-09-102$ & $\underline{2} / 94$ & 75 & 7.1 & 18.2 & -- & -- \\
\hline $38-08-105$ & 90 & 102 & 7.4 & 36.4 & -- & -- \\
\hline$T X-37-10-403$ & 55 & 110 & 1.0 & 2.7 & -- & Recovered for 2 hours. \\
\hline $11-901$ & 50 & 85 & 1.6 & 6.7 & -- & -- \\
\hline \multirow[t]{2}{*}{$13-402$} & 30 & 123 & 1.0 & 5.0 & -- & -- \\
\hline & $2 / 30$ & 123 & -- & 5.0 & .0007 & $\begin{array}{l}\text { Drawdown of observation } \\
\text { well TX-37-13-401. }\end{array}$ \\
\hline 404 & 58 & 180 & 3.6 & 13.4 & -- & Recovered for 2 hours. \\
\hline
\end{tabular}

1/ Modified from Broom (1969) and W. F. Guyton and Associates (1970, 1972).

2/ Length of screen. 
Chemical constituents found in ground water originate principally from the soil and rocks through which the water has passed. Consequently, the chemical character of the water reflects, in a general way, the nature of the geologic formations that have been in contact with the water. Usually ground water in confined aquifers is free from contamination by organic matter. Sometimes, however, ground water in unconfined aquifers may become contaminated when contaminated water percolates from the land surface.

Those factors determining the suitability of water for a particular use are the quality of the water and the limitations imposed by the use. Important criteria used in establishing limitations are bacterial content, temperature, color, taste, odor, and concentration of chemical constituents in the water. Pesticides, if present, also may be a factor in limiting use. A general listing of sources and the significance of dissolved mineral constituents and properties are presented in table 8 (supplemental information).

Wells in Rusk County for which water-quality data are available are listed in table 1. Results of these analyses, showing the source and amount of dissolved constituents are listed in table 4a. Data for certain metals and trace elements are listed in table $4 b$. The analyses included those made by the Geological Survey, other government agencies, and commercial laboratories.

Three samples of ground water were analyzed for pesticides. Water from springs WR-35-57-403 (Big Springs) and WR-37-02-904 (Sulfur Springs) and from well WR-37-03-202 (Mount Enterprise) was analyzed for 28 insecticides and herbicides. None of these water samples contained pesticides in excess of the suggested limits.

For many purposes, the dissolved-solids concentration places a major limitation on the use of ground water. A general classification of water based on the dissolved-solids concentration is as follows (modified after Winslow and Kister, 1956, p. 5):

\begin{tabular}{lc}
\hline \multicolumn{1}{c}{ Description } & $\begin{array}{c}\text { Dissolved-solids concentration } \\
\text { (milligrams per liter) }\end{array}$ \\
Fresh & Less than 1,000 \\
Slightly saline & $1,000-3,000$ \\
Moderately saline & $3,000-10,000$ \\
Very saline & $10,000-35,000$ \\
Brine & More than 35,000 \\
\hline
\end{tabular}

\section{Water-Quality Criteria and Standards}

The Federal Water Pollution Control Act Amendment of 1972 requires that the U.S. Environmental Protection Agency (EPA) publish criteria accurately reflecting the latest scientific knowledge. The law requires that these criteria consider the kind and extent of all identifiable effects upon health and welfare that may result from the presence of any pollutants. Moreover, these criteria should be set forth for all bodies of water including ground water. During 1973, the Environmental Protection Agency published criteria relating 
to the protection of human health and desired species of aquatic plants (National Academy of Sciences, National Academy of Engineering, 1973). During 1976, the Environmental Protection Agency revised the earlier rules (U.S. Environmental Protection Agency, 1977a).

The Environmental Protection Agency's "Quality Criteria for Water, 1976," discusses more than 50 constituents commonly occurring in water. It sets the recommended limits, presents the reason for selecting a given criteria, and cites references relating to these standards. Rules for the primary drinking water regulations were published in the Federal Register (U.S. Environmental Protection Agency, 1976) and became effective July 3, 1979. Rules for the National secondary drinking water regulations were published in the Federal Register (U.S. Environmental Protection Agency, 1979) and became effective January 19, 1981. Al though concentrations of chemical constituents exceeding the recommended limits are objectionable, these limits may sometimes be changed in areas where suitable water is not otherwise available, provided that health and public welfare are adequately protected (U.S. Environmental Protection Agency, 1979).

\section{Aquifers and Geologic Units}

Chemical analyses showing the concentrations of dissolved constituents in water from 158 wells and 2 springs are listed in table $4 a$. About 68 percent of these wells tap the Wilcox aquifer, 18 percent the Carrizo aquifer, and 1 percent the combined Carrizo and Wilcox aquifers. Another 13 percent tap the basal sands of the Reklaw Formation, which are hydraulically connected to the underlying Carrizo. Electric logs are available for many additional wells and are useful in delineating variation in water salinity.

The dissolved-solids concentrations of water from representative wells from the various units are shown in figure 21. Some of the wells inventoried in previous investigations could be relocated only approximately.

Chemical quality of ground water based on electric logs indicates that sand containing slightly saline water sometimes overlies freshwater sands. In places, even the shallow sands yield slightly mineralized water. Water from 28 shallow wells less than 75 feet $(23 \mathrm{~m})$ deep, had concentrations of more than $1,000 \mathrm{mg} / \mathrm{L}$ (milligrams per liter) dissolved solids according to Lyle (1937, p. 72-86). Water from nine of these wells had dissolved-solids concentrations exceeding $3,000 \mathrm{mg} / \mathrm{L}$. Partial analyses of water from two of these wells, WR-35-57-803 and WR-35-60-701, are listed in table 4a.

\section{Midway Group}

Some electric logs indicate that slightly saline water occasionally is present in a sand about 100 feet $(30 \mathrm{~m})$ below the top of the Midway. Where this occurs, the base of slightly saline water is picked at the base of this unit. The presence of this sand also is noted by the Texas Department of Water Resources, which may require use of surface casing to protect the sand from contamination by 0 il and gas production. The Midway, however, does not yield water to wells in Rusk County. 


\section{Wilcox Aquifer}

Water from 107 wells tapping the Wilcox generally was of a sodium bicarbonate type. A calcium magnesium chloride sulfate type of water occurs in several shallow wells (generally less than 300 feet or $91 \mathrm{~m}$ deep), such as WR-35-51-903 and WR-35-52-701. Both types of water in the Wilcox are described in Rusk County by Henry, Basciano, and Duex (1980).

Concentrations of dissolved solids in the 107 samples analyzed ranged from $49 \mathrm{mg} / \mathrm{L}$ (in a 200-foot or $61-\mathrm{m}$ deep well) to $3,430 \mathrm{mg} / \mathrm{L}$ in one well tapping a basal Wilcox sand. Only eight samples exceeded concentrations of $1,000 \mathrm{mg} / \mathrm{L}$ dissolved solids. The electric logs shown in the cross sections (figs. 10-12) also indicate that some of the sand beds in the lower part of the wilcox aquifer contain better quality water than the overlying beds. One example of water-quality zonation in the Wilcox aquifer is illustrated at WR-35-50-804, a test hole drilled for the city of Henderson in 1942. Analyses of water from the well show:

\begin{tabular}{cc}
\hline $\begin{array}{c}\text { Interval sampled } \\
\text { (feet) }\end{array}$ & $\begin{array}{c}\text { Dissolved-solids concentration } \\
\text { (mi lligrams per liter) }\end{array}$ \\
\cline { 2 - 2 } $246-257$ & 292 \\
$493-504$ & 1,116 \\
$600-611$ & 945 \\
$683-694$ & 795 \\
\hline
\end{tabular}

Analyses of water samples collected from well WR-35-50-801, owned by the city of Henderson, show that dissolved-solids concentrations increased from 249 to $328 \mathrm{mg} / \mathrm{L}$ between 1941 and 1983. This well is located between the cone of depression at Henderson and Henderson 0il Field. It is also only half a mile due east of well WR-35-50-804.

\section{Carrizo Aquifer}

Water from each of 31 wells and springs in the Carrizo was analyzed. Most of the wells were less than 100 feet $(30 \mathrm{~m})$ deep. The water usualiy was of a calcium magnesium chloride sulfate type, although sodium and bicarbonate ions were predominant in a few analyses. Only three samples exceeded 1,000 mg/L dissolved-solids concentration.

Spring WR-35-57-406 (Big Springs), once used for public supply, issues from the Carrizo Sand. Water from the spring contained $60 \mu \mathrm{g} / \mathrm{L}$ (micrograms per liter) of chromium and $28 \mu \mathrm{g} / \mathrm{L}$ of lead (see table 4b). The concentration of chromium exceeds the recommended limit of $50 \mu \mathrm{g} / \mathrm{L}$ for public supply use. In 1983, water from Big Springs was reported to be used by some local residents for washing automobiles.

Analyses of water from well WR-35-41-703, tapping the Carrizo-Wilcox, show that the concentration of dissolved solids has increased from 140 to $546 \mu \mathrm{g} / \mathrm{L}$ between 1941 and 1983. This city of Overton well is located along the west side of East Texas 0il Field near the source of Bowles Creek. 
Other Aquifers and Geologic Units

Only one analysis of water from a well tapping the Queen City is listed in table $4 \mathrm{a}$, and the analysis may or may not be representative of water in the aquifer. No analyses of water from the Sparta Sand are included in this report.

Results of analyses of water from 15 wells tapping the Reklaw Formation are listed. Water from two of these wells contained more than $1,000 \mathrm{mg} / \mathrm{L}$ dissolved solids. Two of these wells yielded water with relatively high sulfate concentrations. Analyses also are included in table 4a for two samples collected from wells tapping unknown water-bearing sands.

\section{Contamination and Protection of Ground Water}

Rusk County is a substantial, but declining oil-producing county. During 1980 , it produced $14,900,000$ barrrels $\left(2,370,000 \mathrm{~m}^{3}\right)$ of 011 , down from about $21,164,311$ barrels $\left(3,365,000 \mathrm{~m}^{3}\right)$ of 011 during 1973. Much of this crude was withdrawn from the East Texas $0 i l$ Fjeld, which had a cumulative production of 4.622 billion barrels $\left(734,900,000 \mathrm{~m}^{3}\right)$ of oil through 1980 . The number of producing wells peaked at 25,987 during November 1939 according to the Rail road Commission of Texas. According to the East Texas Salt Water Disposal Company (1958), by January 1, 1958, 29,806 wells had been drilled in the field. At that time there were 19,684 producing wells.

During 1981, pressure-maintenance programs used fresh and slightly saline water from the Wilcox aquifer for oilfield water flooding at a number of oil fields in the area. These include the following fields as shown in figure 5 (and pay zones): East Texas (Woodbine), Pone (basal Pettit), Shiloh (upper Pettit), Tatum (Pettit and lower Pettit), Henderson (Pettit and Travis Peak), and East Henderson (Travis Peak).

\section{Surface Casing}

An act of the Texas Legislature, passed in 1899, requires that oil and gas wells be cased to prevent ground water above the producing zone from entering 011 and gas wells. Later, acts of 1919, 1931, 1932, and 1935, gave broad powers to the Railroad Commission to prevent oil, gas, and water from escaping from the original strata in which they are confined into another strata.

Originally, the Railroad Commission determined where surface casing should be set. Later, the Texas Department of Water Resources and its predecessors was given the authority to make recommendations concerning the protection of usable water. Water containing dissolved-solids concentrations of less than $3,000 \mathrm{mg} / \mathrm{L}$ is recommended for protection by use of surface casing or cement. Recommendation for protection of more highly mineralized water may be made if the water is being used for beneficial purposes.

The depth to the base of sands containing fresh to slightly saline water (in those fields for which field rules exist) and the amount of required cemented surface casing, according to published rules of the Railroad Commission of Texas are shown in figure 22. A recent statewide ruling of the Railroad Commission of Texas in June 1979 relating to the drilling, producing, and 


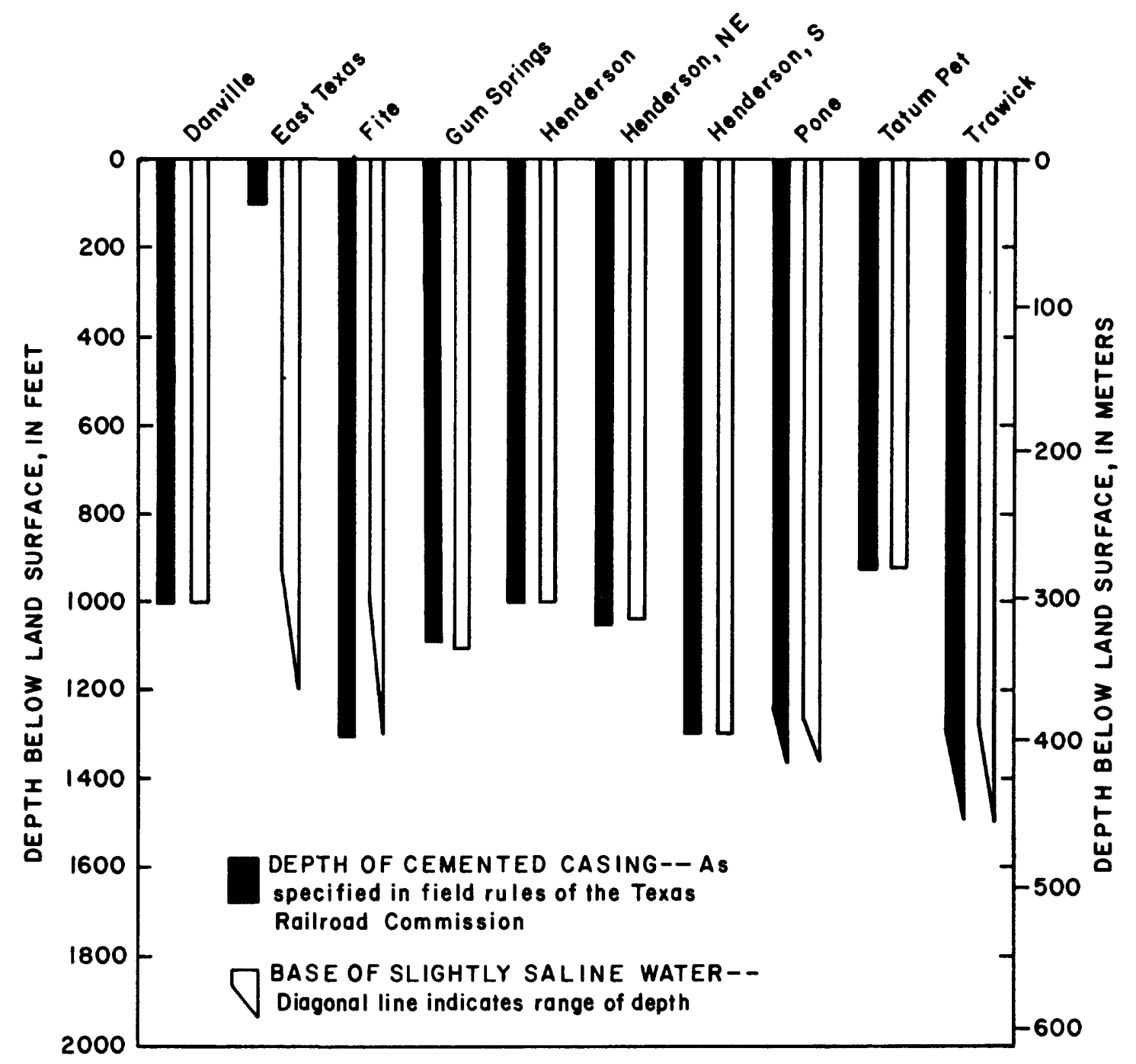

Figure 22.-Relationship between surface-casing requirements and the base of fresh, to slightly saline water, Rusk County 
plugging of any 0 il, gas, or geothermal well requires the protection of usable water both above and below the surface. Also, the Texas Department of Water Resources requires that all fresh and slightly saline water sands be protected. However, according to the original field rules in 1932 for East Texas (Woodbine) $0 i l$ Field, the base of usable water is not adequately protected.

\section{Disposal of Saltwater}

Considerable amounts of brine are produced in Rusk county in connection with the production of oil. If mishandled in improperly cased or plugged oil wells or tests holes, these brines can move upward from the underlying higher pressured saltwater-bearing formations into zones of fresh and slightly saline water. To prevent this, the Railroad Commission requires that brine be disposed of in ways that will not contaminate freshwater.

Between January 1, 1969, (when the Railroad Commission established a rule prohibiting the use of open pits for disposal of oilfield brine) and 1981, nearly all of the brine produced in Rusk County was disposed of through injection wells. Currently (1982), this is particularly true in the area around East Texas $0 i l$ Field where the additional water is needed to maintain reservoir pressure for secondary recovery.

Large quantities of saltwater have been produced from East Texas 0il Field. During some years, the production of saltwater almost equaled the production of oil. The amounts (daily average) of saltwater that were produced, injected, and otherwise diverted for selected years are shown in table 9.

A study of saltwater disposal (Railroad Commission of Texas, 1952, p. 91) showed that during October 1935, East Texas 0il Field had been producing about 15,000 barrels $\left(2,385 \mathrm{~m}^{3}\right)$ of saltwater per day. By 1938, water production had increased to about 100,000 barrels $\left(15,900 \mathrm{~m}^{3}\right)$ per day. During this period, saltwater was pumped into natural drainage systems. Saltwater was first reinjected into the subsurface during June 1938. By 1942, saltwater production had increased to 439,000 barrels $\left(69,800 \mathrm{~m}^{3}\right)$ per day. This was equivalent to about $18.44 \mathrm{Mgal} / \mathrm{d}\left(69,800 \mathrm{~m}^{3} / \mathrm{d}\right)$, of which 18.4 percent was being reinjected into the producing Woodbine sands. About $15 \mathrm{Mgal} / \mathrm{d}\left(56,780 \mathrm{~m}^{3} / \mathrm{d}\right)$ was being otherwise diverted, probably into surface pits and into the natural drainage system.

During 1961, the total brine production for East Texas 0il Field was estimated to be $155,193,391$ barrels $\left(24,675,000 \mathrm{~m}^{3}\right)$. About 99 percent was disposed of through injection wells. About 0.2 percent, $0.4 \mathrm{Mgal} / \mathrm{d}\left(1,500 \mathrm{~m}^{3} / \mathrm{d}\right)$ was disposed of through open surface pits, while another 0.7 percent, $0.12 \mathrm{Mgal} / \mathrm{d}$ $\left(450 \mathrm{~m}^{3} / \mathrm{d}\right)$ was disposed of by unknown methods. (See Texas Water Commission and the Texas Water Pollution Control Board, 1963.)

\section{Contamination}

One case of oilfield brine contamination has been documented at Henderson Field in Rusk County by Burnitt (1963). Contamination was found in an 85-foot (140-m) deep water well (WR-35-50-204) and at three stream sites along the

Beaver Run and Cherokee Bayou drainage areas. Leakage occurred from unlined 
Table 9.--Saltwater production and disposal, East Texas 0il Field

(Figures modified from East Texas Salt Water Disposal Co., 1958, and Texas Water Commission and Texas Water Pollution Control Board, 1963)

\begin{tabular}{|c|c|c|c|c|c|c|}
\hline \multirow[t]{2}{*}{ Year } & \multicolumn{2}{|c|}{$\begin{array}{l}\text { Saltwater produced } \\
\text { (daily average) }\end{array}$} & \multicolumn{2}{|c|}{$\begin{array}{l}\text { Saltwater injected } \\
\text { (daily average) }\end{array}$} & \multicolumn{2}{|c|}{$\begin{array}{c}\text { Saltwater otherwise diverted } \\
\text { (daily average) }\end{array}$} \\
\hline & Barrets & $\begin{array}{l}\text { Million } \\
\text { gallons }\end{array}$ & Barrels & $\begin{array}{l}\text { Million } \\
\text { gallons } \\
\end{array}$ & Barrels & $\begin{array}{l}\text { Million } \\
\text { gallons } \\
\end{array}$ \\
\hline 1935 & 15,000 & 0.63 & 0 & 0 & 15,000 & 0.63 \\
\hline 1938 & 100,000 & 4.20 & 610 & .03 & 100,000 & 4.17 \\
\hline 1942 & 439,000 & 18.44 & 81,000 & 3.40 & 358,000 & 15.04 \\
\hline 1950 & 643,000 & 27.00 & 466,000 & 19.57 & 177,000 & 7.43 \\
\hline 1961 & 433,000 & 18.19 & 429,000 & 18.02 & 4,000 & 0.17 \\
\hline
\end{tabular}

NOTE: Figures may vary slightly due to rounding procedures. 
surface pits, formerly used for storing oilfield brines. Analyses of water collected from the contaminated well show relatively high amounts of calcium, sodium, chloride, and total dissolved solids, and a relatively low pH. The first sample was collected after 1 minute of pumping; the second sample after 5 hours of pumping. During this period, the total dissolved solids increased from 1,870 to $2,475 \mathrm{mg} / \mathrm{L}$; the $\mathrm{pH}$ declined from 6.5 to 5.6 . Water collected from one stream site contained $50 \mathrm{mg} / \mathrm{L}$ of dissolved solids. Water collected from the three contaminated stream sites had dissolved-solids concentrations of $116,880,6,684$, and $6,609 \mathrm{mg} / \mathrm{L}$.

Hughes and Leifeste (1967) completed a reconnaissance of water quality of surface water in the Neches River basin. Their study includes data on Striker Creek Lake and the Striker Creek drainage basin, which also includes the Bowles Creek watershed. Water samples were collected during low flows from 24 sites in the Striker Creek basin during March and June 1964. Hughes and Leifeste (1967, p. A21) reported that some earthen pits were still used to store oilfield brine. They also observed oil wastes along the banks of water courses, which indicated that there had been brine spills. "In addition to deliberate dumping," reported Hughes and Leifeste, "brine also reaches streams as a result of leaks in collection systems, breaks in pipelines, overflow of storage tanks, and other accidents incidental to the handling of large volumes of waste water." The following are conclusions they reached:

1. Bowles Creek and its tributaries are the source of most of the salinity;

2. Many streams carry acid water with the $\mathrm{pH}$ as low as 3.2 ;

3. Sodium and chloride are the principal dissolved constituents;

4. Sulfate concentrations generally are low throughout the area;

5. Where acid water occurs outside the oilfield area, sulfate is the principal anion; and

6. High chloride water was not found outside the oilfield area.

DEVELOPMENT AND USE OF GROUND WATER

History of Development

Prior to about 1920, nearly all the water used in Rusk County came from shallow wells dug into the Wilcox and Carrizo aquifers. Numerous springs (there may be as many as several hundred) also provide water throughout much of the area. Brune (1981, p. 390-394) in "Springs of Texas" lists 43 springs of historical interest. Many of these are located along the Mount Enterprise Fault Zone. Stockman Springs (WR-37-03-403), west of Mount Enterprise, is located along the East Fork of the Angelina River. Brune reports that in 1833, Henry Stockman received a land grant which included the springs now named after him. He also relates that Stockman, along with a yoke of oxen, drowned in the springs. Other springs such as Sulphur Springs (WR-37-02-904) are of similar extent.

The discovery of East Texas 0il Field in 1930 created an immediate demand for water to be used for industrial purposes. Almost all of this withdrawal was from the Carrizo and Wilcox aquifers. Turner (1932, p. 6) estimated that about $16.2 \mathrm{Mgal} / \mathrm{d}\left(61,317 \mathrm{~m}^{3} / \mathrm{d}\right)$ was being withdrawn for oilfield operations in Rusk and Gregg Counties. The cities of Kilgore (Gregg and Rusk Counties) and Longview (Gregg County) at first used water from the Sabine River. By 1934, 
concentrations of oilfield brines and industrial wastes became so high during low flow in the Sabine River that these cities located other sources of drinking water. For a while Longview diverted creek water for drinking, but now (1982) uses water from Lake Cherokee (Rusk and Gregg Counties). Kilgore withdraws ground water from well fields in Smith County.

When Lyle (1937) inventoried 406 wells in Rusk County, only 15 were classified as industrial, 8 as public supply, and 16 as "oilfield" use. Most of the larger-capacity wells were concentrated around East Texas 0il Field and the city of Henderson. Elsewhere, shallow-dug wells were used for domestic and stock purposes.

Much of the industrial use of ground water is related to the production of $0 i 1$ and gas with most of the withdrawals concentrated in East Texas 0il Field. Follett (1943) inventoried those industrial wells in the northwestern part of the county. During 1981, water levels were measured in some of the same wells he visited.

Shallow wells continued to be used rather extensively in the area until the late 1960's and early 1970's. By then, a number of rural water-supply corporations were organized under the auspices of the Farmers Home Administration. During 1981, there were 24 active water-supply corporations serving residents of Rusk county. These systems, together with the municipalities of Henderson, Overton, New London, and Tatum, supply about 90 percent of the water used for domestic and stock purposes.

\section{Use of Water}

Withdrawals of ground water during 1960, 1970, and 1980 are summarized by use in table 10. During 1980, all significant withdrawals of ground water, about $4.6 \mathrm{Mgal} / \mathrm{d}\left(17,411 \mathrm{~m}^{3} / \mathrm{d}\right)$, were from the Wilcox aquifer. Of this amount, about 94 percent was freshwater. Numerous springs, creeks, and ponds supply the water needs for livestock. Surface water is used for some public supply and industrial purposes. The Elderville Water-Supply Corporation obtains water from Lake Cherokee through the City of Longview; Texas Utilities Generating Company uses Martin Lake as a source of cooling water at their generating plant.

\section{Municipal Use}

Estimates of municipal use of ground water are listed in table 11 . Of the $4.20 \mathrm{Mgal} / \mathrm{d}\left(15,900 \mathrm{~m}^{3} / \mathrm{d}\right)$ of ground water used for public supply, $3.23 \mathrm{Mgal} / \mathrm{d}$ $\left(12,230 \mathrm{~m}^{3} / \mathrm{d}\right)$ of water was used by the five municipalities listed in table 11 . The City of Henderson, the largest single user, pumped $2.05 \mathrm{Mgal} / \mathrm{d}\left(7.760 \mathrm{~m}^{3} / \mathrm{d}\right)$ of ground water from the Wilcox during 1980. The average per capita consumption of ground water from the five largest communities was $190 \mathrm{gal} / \mathrm{d}\left(0.7 \mathrm{~m}^{3} /\right.$ d). The 24 rural water-supply corporations serving the smaller communities furnished about $0.97 \mathrm{Mgal} / \mathrm{d}\left(3,670 \mathrm{~m}^{3} / \mathrm{d}\right)$ or about 23 percent of the water used for public supply during 1980. The approximate area served by all 29 public water-supply systems in Rusk County is shown in figure 23. El derville Water Supply Corporation, which uses surface water from Lake Cherokee, is the only public supply system that does not use ground water. 
Table 10.--Approximate withdrawals of ground water during 1960,1970 , and 1980 in Rusk County

(Mgal/d, million gallons per day; acre-ft, acre-feet)

\begin{tabular}{|c|c|c|c|c|c|c|}
\hline \multirow[t]{2}{*}{ Use } & \multicolumn{2}{|c|}{1960} & \multicolumn{2}{|c|}{1970} & \multicolumn{2}{|c|}{1980} \\
\hline & Mgal/d & Acre-ft & $\mathrm{Mgal} / \mathrm{d}$ & Acre-ft & $\overline{\mathrm{MgaT} / \mathrm{d}}$ & Acre-ft \\
\hline Industrial & 1.20 & 1,344 & 1.15 & 1,288 & 0.50 & 504 \\
\hline Mining1/ & -- & -- & .04 & 45 & .55 & 616 \\
\hline Public supply & 1.40 & 1,568 & 2.25 & 2,520 & 4.20 & 4,705 \\
\hline Rural domestic & .50 & 560 & .08 & 90 & .15 & 224 \\
\hline Totals & 3.10 & 3,472 & 3.52 & 3,943 & 5.40 & 6,049 \\
\hline
\end{tabular}

1/ Includes slightly saline water. 
Table 11.--Municipal use of ground water in Rusk County

\begin{tabular}{|c|c|c|c|c|c|c|}
\hline Municipality & $\begin{array}{l}1980 \\
\text { Popu- } \\
\text { lation }\end{array}$ & $\begin{array}{c}1980 \\
\text { Per capita } \\
\text { consumption } \\
\text { (gallons) }\end{array}$ & $\frac{1942}{(m}$ & $\frac{1943}{\text { Tion gal }}$ & $\frac{1970}{\text { ns per }}$ & $\frac{1980}{\text { day) }}$ \\
\hline Hen derson & 11,473 & 178 & 0.36 & $1 / 0.38$ & 1.27 & 2.05 \\
\hline Mount Enterprise & 485 & 365 & -- & -- & .07 & .18 \\
\hline New London & 942 & 400 & -- & -- & .22 & .38 \\
\hline Overton & 2,430 & 178 & $1 / .20$ & $\underline{2} / .20$ & .29 & .43 \\
\hline Tatum & 1,614 & 120 & -- & .01 & -- & .19 \\
\hline Totals & 16,944 & $\underline{3} / 190$ & 0.56 & 0.59 & 1.85 & 3.23 \\
\hline
\end{tabular}

1/ November and December estimated on 1941 basis.

2/ Estimated.

3/ Average per capita consumption.

NOTE: Some figures may vary slightly due to rounding. 


\section{Industrial Use}

Industrial use during 1980 was estimated to be about $0.50 \mathrm{Mgal} / \mathrm{d}(1,892$ $\left.\mathrm{m}^{3} / \mathrm{d}\right)$, a decline of more than 50 percent from 1970. Nearly all of the industrial use is for cooling at gasoline plants and refineries. Increased energy costs have caused some operators to replace ground water with more economical sources of cooling, such as air and liquid hydrocarbons. Other industrial users have abandoned their wells and now obtain water from public-supply sources.

\section{Mining Use}

Withdrawals of water for mining (fuels) are reported to the Railroad Commission of Texas. During 1980, about $0.550 \mathrm{Mgal} / \mathrm{d}\left(2,082 \mathrm{~m}^{3} / \mathrm{d}\right)$ of water was withdrawn from the Wilcox aquifer for pressure maintenance. One example of such a project, Mobil's T. 0. Mason lease, is pictured in figure 24. Here, slightly saline water from the Wilcox is treated and mixed with produced brine from the Woodbine. This fluid is then injected underground in secondary recovery of oil at East Texas 0il Field. Pressure maintenance operations (water flooding) are or have been underway at eight oilfield sites in East Texas, two in Tatum, one in Henderson, one in South Henderson, one in Pone, and one in Shiloh.

\section{Changes in Water Levels}

Most water levels in Rusk County were measured during three periods: During 1936, between 1937 and 1940, and from about 1972 through 1981. Most of the observation wells before 1972 were concentrated near the city of Henderson. During 1972, the Texas Department of Water Resources initiated a network of observation wells that included the entire county. Practically no water-level data are available prior to the discovery of East Texas 0il Field in 1930.

Water-level measurements (three or less) are listed in the records of wells, springs, and test holes (table 1). Other measurements (four or more) are tabulated in the list of water levels in wells (table 3). Hydrographs depicting water-level fluctuations in selected wells are shown in figure 25.

Many of the water levels measured are in wells that show no particular change. These water levels rise and fall due to changes in season and variations in rainfall. Sustained long-term declines in water levels are evident in two places, near the city of Henderson and in the area of East Texas 0il Field. In both areas there is a concentration of wells producing an average of over a million gallons per day. Most of the wells withdraw water from the middle and lower Wilcox sands.

At the city of Henderson, a moderate cone of depression (fig. 18) has resulted from ground-water withdrawals of about $2.0 \mathrm{Mgal} / \mathrm{d}\left(7,570 \mathrm{~m}^{3} / \mathrm{d}\right)$. The water level in well WR-35-50-901, near Henderson, declined about 134 feet (41 m) between 1935 and 1981 (fig. 25).

Water levels in well WR-35-41-703 declined 29 feet (9 m) between 1941 and 1979; water levels in well WR-35-41-901 declined about 17 feet $(5 \mathrm{~m})$ between 1949 and 1981; and water levels in well WR-35-49-702 declined 67 feet (20 m) 


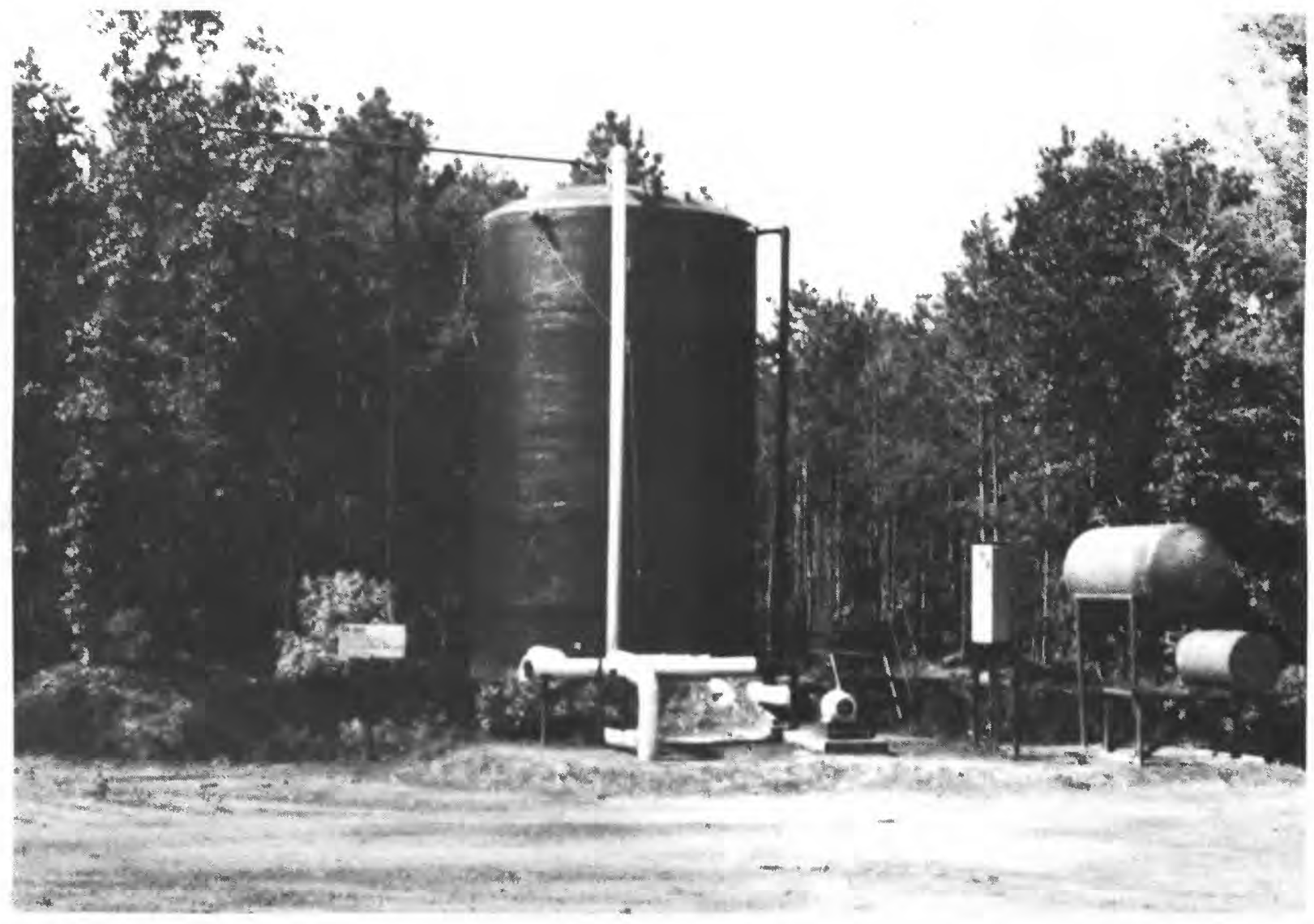

Figure 24.- Water-storage tank at Mobll's T.O. Mason pressuremaintenance project in East Texas Oil Field 


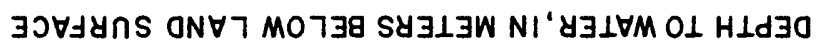

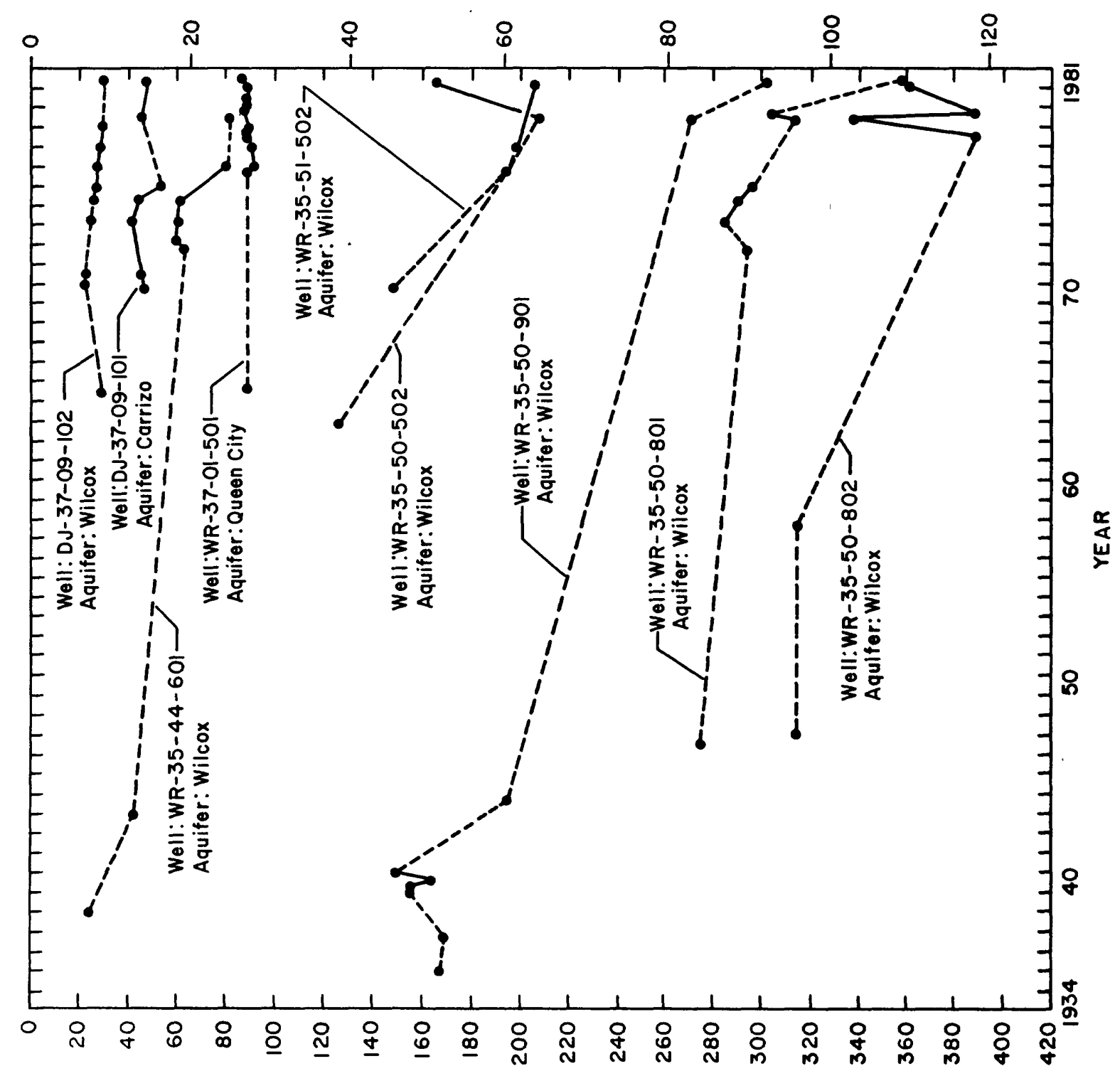

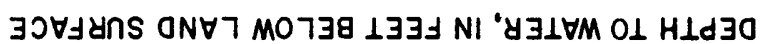


between 1938 and 1979. However, not all water levels in Rusk county declined. The water level in well WR-35-41-501 rose 43 feet (13 m) between 1947 and 1979. The water level in well WR-35-44-601, tapping the Wilcox, declined about 54 feet $(16 \mathrm{~m})$ between 1938 and 1979. Elsewhere in Rusk County, water levels in most wells have not declined appreciably. For example, the water level in well WR-37-01-501 (fig. 25), tapping the Queen City, shows no long-term change.

\section{Well Construction}

Well construction depends on several factors such as the desired capacity of the well, intended use, allowable cost, methods of drilling, and quality of the water desired. Some information on the well construction used in the county is tabulated in table 1. Except for shallow-dug wells, wells are cased and have slotted screen opposite water-bearing sands.

Large-capacity wells such as those used for industrial and municipal supply are drilled by hydraulic rotary methods. First, a test hole (usually 6 inches or $152 \mathrm{~mm}$ in diameter) is drilled to total depth and logged for thickness of sand intervals. Water samples are collected to determine water qual$i$ ty in the different sands. If the data indicate that sufficient quantities of suitable quality water can be developed, a well is constructed. Test drilling is necessary in much of Rusk County, but particularly in the Mount Enterprise Fault Zone or in areas where the Wilcox sands contain water that varies in quality.

In a typical large-capacity well, the upper part of the test hole usually is reamed to 14-20 inches $(355-510 \mathrm{~mm})$ in diameter. A slightly smaller surface casing is set and cemented in place to form the pump pit or housing. The remaining part of the test hole is then reamed to a diameter slightly less than that of the surface casing. The interval to be screened is then underreamed as desired, usually to 30 inches $(760 \mathrm{~mm})$ in diameter, and 8-12 inch (205-305 $\mathrm{mm}$ ) diameter wire-wrapped screens and blank casing are installed. Next, the annular space between the screen or casing and the wall of the hole is filled with sorted gravel. This gravel pack stabilizes the hole and effectively increases the diameter of the well. Large-capacity wells are developed and tested with large-capacity pumps. The wells then are fitted with deep-well turbine pumps, usually powered by electric motors. Porperly constructed wells in the Wilcox or Carrizo aquifers yield about $500 \mathrm{gal} / \mathrm{min}(32 \mathrm{~L} / \mathrm{s})$.

Most of the drilled wells used for stock and domestic purposes in Rusk County have 2- to 4-inch (51- to 102-mm) casing. Generally, jet pumps are used for the smaller-diameter wells if the water level is near the surface, and submersible pumps are used in the deeper 4-inch (102-mm) wells. Plastic (PVC) casing is often used due to its lower cost and ability to resist corrosion from water having a low pH or high iron content. Often the 4-inch (102-mm) wells are completed with a smaller-diameter single screen placed at the bottom of the well. Sometimes a wire-wrapped screen is used. More frequently, however, the last joint of pipe is slotted or perforated and possibly gravel packed. 
Some freshwater is available from every formation above the Midway Group. Only the Carrizo and Wilcox aquifers, however, are capable of producing substantial quantities of water. The Sparta and Queen City Sands, as previousiy mentioned, are limited in thickness and extent and only rarely are tapped by large wells in Rusk county. Although basal sands of the Reklaw furnish some water, they are hydraulicaliy connected with the underlying Carrizo and should not be considered a source of water apart from the Carrizo. Moreover, the Reklaw, Queen City, Weches, and Sparta also overlie the Carrizo and Wilcox aquifers. Consequently, there is almost always a higher-yielding, but deeper, source of ground water available from the Carrizo and Wilcox sands.

It is not known if the current level of freshwater withdrawal will be maintained for the foreseeable future. If it is, a continued but moderate lowering of the potentometric surface is expected. With withdrawal of ground water, the lowering of water levels continues until the area of influence from the well fields becomes large enough so that the recharge equals the discharge. While water levels are lowered, water is taken from storage. The potentiometric surface of the Wilcox aquifer (fig. 18) indicates that the area of influence already extends past the Rusk county line. There are not sufficient withdrawal or water-level data to determine if the general water-level declines shown in figure 25 will continue permanently because of continued increases in pumpage or only be temporary because of recent increases in pumpage. Data are insufficient to construct a water-level decline map for Rusk County.

In the case of the Wilcox and Carrizo aquifers in Rusk County, the recharge may be effectively increasing as the water levels are drawn down. Additional drawdown causes an increase in the head differences between the water table, which is expected to remain reasonably stable, and the potentiometric surface of the major water-bearing zones. Thus, the vertical hydraulic gradient is increased, thereby proportionally increasing the vertical leakage or movement of water.

One unknown aspect of continuing or increasing the ground-water withdrawals from the Wilcox is the possibility of increasing the water's salinity. As the water levels are lowered, water movement from nearby zones occurs. If these zones contain water of a higher salinity, the dissolved-solids concentrations in the major freshwater zones would be expected to eventually increase.

\section{Wilcox and Carrizo Aquifers}

Fresh to slightly saline water is available from the Wilcox aquifer throughout the entire 939 square miles $\left(2,432 \mathrm{~km}^{2}\right)$ of Rusk County. The average thickness of sand in the Wilcox containing freshwater in Rusk County is about 245 feet $(75 \mathrm{~m})$. Based upon a porosjty of 30 percent, the wilcox contains about 40 million acre-feet $\left(49,300 \mathrm{hm}^{3}\right)$ of water; however, it is economically impractical to recover more than a small percentage of this water. Assuming a specific yield of 0.15 , about 20 million acre-feet $\left(24,660 \mathrm{hm}^{3}\right)$ of water is available from storage. Water in storage is not a good measure of availability in Rusk County because it is not economically practical to recover more than a moderate amount of the total water stored in the aquifer system. 
Also, because the slightly saline water-bearing sands are interbedded with the freshwater-bearing sands, chemical quality may be a deterrent to development.

Freshwater is available from the Carrizo wherever it is present in Rusk County. Based on an area of 656 square miles $\left(1,699 \mathrm{~km}^{2}\right)$, a porosity of 30 percent, and an average sand thickness of 70 feet $(21 \mathrm{~m})$, the aquifer contains about 8 million acre-feet $\left(9,864 \mathrm{hm}^{3}\right)$ of water. Assuming a specific yield of 0.15 and an overall average sand thickness of 70 feet $(21 \mathrm{~m})$, about 4 million acre-feet $\left(4,932 \mathrm{hm}^{3}\right)$ of water is available from storage in the Carrizo. The Carrizo is in hydraulic continuity with and serves as an avenue of recharge to the Wilcox throughout much of Rusk County.

Moderate amounts of ground water are available for development. The amount that is available perennially is not known, but is greater than that being withdrawn. Assuming a pre-development hydraulic gradient of about $8 \mathrm{ft} / \mathrm{mi}(1.5 \mathrm{~m} /$ $\mathrm{km})$, a hydraulic conductivity of $14 \mathrm{ft} / \mathrm{d}(4.3 \mathrm{~m} / \mathrm{d})$, and an average freshwater sand thickness of 245 feet $(74.7 \mathrm{~m})$, at least $12 \mathrm{Mgal} / \mathrm{d}(45,420 \mathrm{~m} / \mathrm{d})$ of fresh ground water is being transmitted through the Wilcox and about $3 \mathrm{Mgal} / \mathrm{d}(11,350$ $\mathrm{m}^{3} / \mathrm{d}$ ) through the Carrizo.

\section{Other Aquifers}

The Queen City aquifer, present in about 10 percent of the county, is practically undeveloped. Maximum thickness of the Queen City is about 132 feet $(40 \mathrm{~m})$. The aquifer is capable of producing ample supplies of ground water for stock and domestic use. The Sparta Sand aquifer, which only occurs locally in the vicinity of the Mount Enterprise Fault system, is practically undeveloped. Because of their limited extent and near-surface occurrence, neither the Sparta nor Queen City is an important aquifer in Rusk County.

\section{Areas Most Favorable for Future Development}

Areas most favorable for future development of ground water are shown in figure 26. These areas have been designated as follows: I, most favorable; II, favorable; III, moderately favorable; IV, moderately unfavorable; and V, most unfavorable.

Representative criteria useful in classifying the favorability of areas for additional freshwater development include: 1, hydraulic conductivity; 2, average thickness of freshwater-bearing sands; 3 , amount of ground water being. withdrawn; 4, thickness or amount of slightly saline water-bearing sands interbedded with freshwater sands; 5, possible effects of faulting; and 6, possibility of freshwater sands being mineralized by oilfield brines.

The most favorable region for future development, shown as area $I$ in figure 26, is located in southwestern Rusk County. The area has one of the thicker sections of freshwater-bearing Wilcox sands, and the Carrizo is present in about 95 percent of the area. Also no significant ground-water withdrawals occur in the area. 


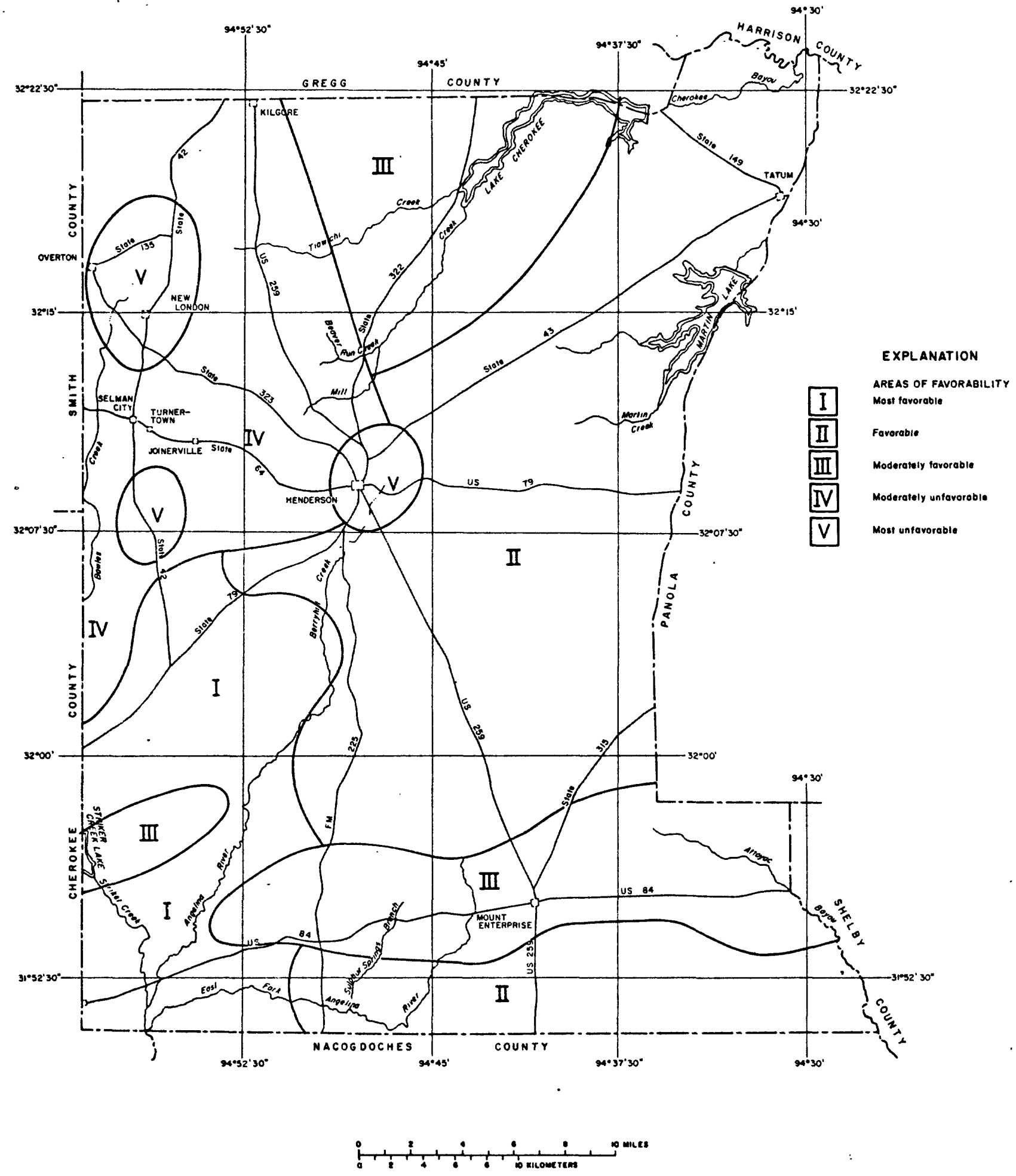


Two favorable areas, shown as area II, are present. One lies in the eastcentral part of the county east of Henderson and another is present south of the Mount Enterprise Fault System. Although some Carrizo crops out on the surface in both areas, the largest ground-water supplies could be developed from the Wilcox aquifer.

Three moderately favorable areas, shown as area III, are present. Two of these areas are located in the southern section of the county and are associated with the Mount Enterprise Fault System. Outliers of both the Queen City and Sparta are preserved in the downdropped blocks of the system. Consequently, these are the places where the most complete geologic section is developed. Although there could be considerable amounts of available freshwater in this area, development of individual wells should be considered carefully because faulting may have interrupted the lateral continuity of a producing zone. The other moderately favorable area is located in the north-central part of the county where the freshwater-bearing Wilcox sands are relatively thin.

The moderately unfavorable area, shown as area IV, extends from about the city of Henderson northwestward to the county line. The area has experienced a substantial decline in water levels and has encountered some brine pollution.

Three most unfavorable areas, shown as area $V$, are present. One of the areas, about 30 square miles $\left(78 \mathrm{~km}^{2}\right.$ ) near the city of Henderson, accounts for about 40 percent of all ground water withdrawn in the county and may be considered moderately developed. Two other areas are located between Overton and New London and at Price in the area of East Texas 0il Field. This is an area where there are two cones of depression and considerable interfingering of slightly saline water-bearing sands with freshwater sands.

\section{NEEDS FOR CONTINUING DATA COLLECTION}

Collection of withdrawal, water-level, and water-quality data in Rusk County should be continued and expanded. During about 1972, the Texas Department of Water Resources initiated a program of measuring water levels and collecting water-quality data in the area. The data-collection program should be continued and could be expanded to include a few wells that tap the deeper Wilcox sands outside of the more heavily pumped areas. Water-quality data also could be collected at Henderson to monitor saltwater encroachment.

A ground-water program to investigate contamination of freshwater sands by oilfield brines could be initiated in the East Texas and Henderson $0 i 1$ Fields. Emphasis of such a program should be placed on investigating the deeper sands of the Wilcox as well as the shallow sands in areas of recharge.

\section{CONCLUSIONS}

The Wilcox aquifer is the major source of ground water in Rusk county. It yields both fresh and slightly saline water. Water can also be obtained from the Carrizo, Queen City, and Sparta aquifers and from the Reklaw Formation. The Carrizo, the most extensive of the other sources, is in hydrologic continuity with the underlying Wilcox. 
Numerous facies changes are present within the Wilcox, which consists of thin but sometimes massive beds of fine to coarse grained sand, silt, and clay. The aquifer ranges in thickness from about 750 feet $(229 \mathrm{~m})$ to more than 1,200 feet $(366 \mathrm{~m})$. The Wilcox is the only freshwater-bearing unit that is present throughout all of Rusk Conty. No freshwater occurs below the base of the Wilcox. In places, however, slightly saline water-bearing beds are interbedded with and sometimes overlie freshwater-bearing sands. Although some of these relationships are natural, others may result from the mineralization of water by oilfield brines.

Daily withdrawal of ground water for all purposes increased from $3.1 \mathrm{Mgal} / \mathrm{d}$ $\left(11,750 \mathrm{~m}^{3} / \mathrm{d}\right)$ during 1960 to $5.4 \mathrm{Mgal} / \mathrm{d}(20,450 \mathrm{~m} / \mathrm{d})$ during 1980 . Daily withdrawal for municipal purposes has increased from $1.4 \mathrm{Mgal} / \mathrm{d}\left(5,300 \mathrm{~m}^{3} / \mathrm{d}\right) \mathrm{dur}$ ing 1960 to $4.2 \mathrm{Mgal} / \mathrm{d}(15,900 \mathrm{~m} / \mathrm{d})$ during 1980 . About half of the municipal and about 38 percent of the total ground-water withdrawal (1980) is from a small area around the city of Henderson. Consequently, water levels at Henderson have declined about 135 feet $(41 \mathrm{~m})$ or an average of about 2.9 feet $(0.9$ m) per year between 1935 and 1981 .

Additional supplies of fresh ground water can be developed throughout nearly all of Rusk County. About $20 \mathrm{million}$ acre-feet $\left(24,660 \mathrm{hm}^{3}\right)$ of freshwater is available from storage, and a total of $12 \mathrm{Mgal} / \mathrm{d}\left(46,650 \mathrm{~m}^{3} / \mathrm{d}\right)$ is being transmitted through the Wilcox aquifer. Slightly saline water also is available from the wilcox aquifer. About 4 million acre-feet $\left(4,932 \mathrm{hm}^{3}\right)$ of freshwater is available from storage, and a total of about $3 \mathrm{Mgal} / \mathrm{d}(11,200$ $\mathrm{m}^{3} / \mathrm{d}$ ) is being transmitted through the Carrizo aquifer. Wells that are properly constructed should yield about $500 \mathrm{gal} / \mathrm{min}(32 \mathrm{~L} / \mathrm{s})$ from the Wilcox and possibly the Carrizo aquifers; a few wells have been constructed that yield as much as $1,000 \mathrm{gal} / \mathrm{min}(63 \mathrm{~L} / \mathrm{s})$.

Much of the variation in the quality of the ground water in the wilcox aquifer is natural. Three areas in which variations are likely to occur are near the city of Henderson, in the East Texas 0il Field, and along the Mount Enterprise Fault System. Because drastic water-quality changes occur between zones, it is essential that the water from each sand be analyzed during a testdrilling operation to make certain that it is of acceptable quality.

Poor-quality ground water occurs in the vicinity of the city of Henderson. The withdrawal of $2.05 \mathrm{Mgal} / \mathrm{d}(7,760 \mathrm{~m} / \mathrm{d})$ of ground water from the Wilcox during 1980 created a cone of depression into which the poor-quality water could migrate.

Ground water has been contaminated by oilfield brine at Henderson field. In addition, oilfield brine has contaminated Bowles Creek and Beaver Run Creek in two separate instances. 


\section{SELECTED REFERENCES}

American Public Health Association and others, 1975, Standard methods for the examination of water and wastewater (14th ed.): Washington, D.C., American Public Health Association, $1193 \mathrm{p}$.

Baker, B. B., Dillard, J. W., Souders, V. L., and Peckham, R. C., 1963, Reconnaissance investigation of the ground-water resources of the Sabine River basin, Texas: Texas Water Commission Bulletin 6307, 63 p.

Baker, B. B., Peckham, R. C., Dillard, J. W., and Souders, V. L., 1963, Reconnaissance investigation of the ground-water resources of the Neches River basin, Texas: Texas Water Commission Bulletin 6308, 67 p.

Broadhurst, W. L., 1945, Records of wells, drillers' logs, water analyses, and map showing locations of wells in Gregg County, Texas: Texas Board of Water Engineers report, $35 \mathrm{p}$.

Broom, M. E., 1969, Ground-water resources of Gregg and Upshur Counties, Texas: Texas Water Development Board Report 101, 83 p.

Brune, Gunnar, 1981, Springs of Texas, volume 1: Fort Worth, Branch-Smith, Inc., $566 \mathrm{p}$.

Burnitt, S. C., 1963, Henderson 0il Field area, Rusk County, Texas; Investigation of ground-water contamination: Texas Water Commission report, $13 \mathrm{p}$.

California State Water Quality Control Board, 1963, Water-quality criteria: California State Water Quality Control Board Publication 3-A.

Collins, E. W., Hobday, D. K., and Kreitler, C. W., 1980, Quaternary faulting in East Texas: University of Texas, Bureau of Economic Geology Geological Circular 80-1, $30 \mathrm{p}$.

Cooper, H. H., and Jacob, C. E., 1946, A generalized graphical method for evaluating formation constants and summarizing well-field history: American Geophysical Union Transactions, v. 27, no. IV, p. 526-534.

Dean, H. T., and others, 1941, Domestic water and dental caries: Public Health Report, v. 56, p. 761-792.

Deussen, Al exander, 1914, Geology and underground waters of the southeastern part of the Texas Coastal Plain: U.S. Geological Survey Water-Supply Paper $335,365 \mathrm{p}$.

Dillard, J. W., 1963, Availability and quality of ground water in Smith County, Texas: Texas Water Commission Bulletin 6302, 116 p.

Dougherty, J. P., 1975, Evaporation data in Texas: Texas Department of Water Resources report, $237 \mathrm{p}$.

East Texas Salt Water Disposal Company, 1958, Salt-water disposal, East Texas 0il Field: $131 \mathrm{p}$.

Eaton, R. R., 1956, Resume of subsurface geology of northeast Texas with emphasis on salt structures: Transactions of the Gulf Coast Geological Societies, p. 79-84.

Fenneman, N. M., 1939, Physiography of eastern United States: New York, McGraw$\mathrm{Hi} 1 \mathrm{~T}, 714 \mathrm{p}$.

Ferris, J. G., Knowles, D. B., Brown, R. H., and Stallman, R. W., 1962, Theory of aquifer tests: U.S. Geological Survey Water-Supply Paper 1536-E, 173 p.

Fisher, W. L., 1965, Rock and mineral resources of east Texas: University of Texas, Bureau of Economic Geology Report of Investigations 54, $439 \mathrm{p}$.

Fisher, W. L., and McGowen, J. H., 1967, Depositional systems in the Wilcox Group of Texas and their relationship to occurrence of oil and gas: Gulf Coast Association of Geological Societies, Transactions of 17 th annual meeting, p. 105-125. 
Follett, C. R., 1943, Records of wells, drillers' logs, water analyses, and map showing locations of wells in Rusk County, Texas: Texas Board of Water Engineers, $56 \mathrm{p}$.

W. F. Guyton and Associates, 1970, Ground-water conditions in Angelina and Nacogdoches Counties, Texas: Texas Water Development Board Report 110, $167 \mathrm{p}$.

1972, Ground-water conditions in Anderson, Cherokee, Freestone, and Henderson Counties, Texas: Texas Water Development Board Report 150, $335 \mathrm{p}$.

Hem, J. D., 1959, Study and interpretation of the chemical characteristies of natural water: U.S. Geological Survey Water-Supply Paper 1473, 269 p.

1970, Study and interpretation of the chemical characteristics of natural water: U.S. Geological Survey Water-Supply Paper 1473, $363 \mathrm{p}$.

Henry, Christopher, Basciano, J. M., and Duex, T. W., 1980, Hydrology and water quality of the Eocene Wilcox Group; Significance for lignite development in East Texas: University of Texas, Bureau of Economic Geology, 9 p.

Hughes, L. S., and Leifeste, D. L., 1967, Reconnaissance of the chemical quality of surface waters of the Neches River basin, Texas: U.S. Geological Survey Water-Supply Paper 1839-A, $63 \mathrm{p}$.

Jones, P. H., Stevens, P. R., Wesselman, J. B., and Wallace, R. H., Jr., 1976, Regional appraisal of the Wilcox Group in Texas for subsurface storage of fluid wastes: Part I - Geology: U.S. Geological Survey Open-File Report 76-394, $107 \mathrm{p}$.

Kaiser, W. R., Ayers, W. B., Jr., and La Brie, L. W., 1980, Lignite resources in Texas: University of Texas, Bureau of Economic Geology and Texas Energy and National Resources Advisory Council Report of Investigations No. 104, $52 \mathrm{p}$.

Kane, J. W., 1967, Monthly resevoir evaporation rates for Texas, 1940 through 1965: Texas Water Develpoment Board Report 64, $111 \mathrm{p}$.

Kreitler, C. W., and others, 1980, Geology and geohydrology of the East Texas basin: University of Texas, Bureau of Economic Geology Geological Circular 80-12, $112 \mathrm{p}$.

Lockhart, E. E., Tucker, C. L., and Merritt, M. C., 1955, The effect of water impurities on the flavor of brewed coffee: Food Research 20, 598 p.

Lyle, W. M., 1937, Records of wells, drillers' logs, water analyses, and map showing location of wells in Rusk County, Texas: Texas Board of Water Engineers report, $87 \mathrm{p}$.

Maxcy, K. F., 1950, Report on the relation of nitrate concentrations in well waters to the occurrence of methemoglobinemia: National Research Council Bulletin, Sanitary Engineering, App. D, p. 265-271.

McKee, J. E., and Wolf, H. K., 1963, Water quality criteria (2d ed.): California State Water Quality Board Publication No. 3-A, $548 \mathrm{p}$.

Meinzer, 0. E., and Wenzel, L. K., 1942, Movement of ground water and its relation to head, permeability and storage, in physics of the earth, Part 9, Hydrology: New York, McGraw-Hi11, p. 444-478.

Morton, R. B., 1981, Effects of petroleum associated brine on the water resources of the Vamoosa-Ada aquifer, east-central Oklahoma: U.S. Geological Survey Open-File Report 81, $60 \mathrm{p}$.

National Academy of Sciences, National Academy of Engineering, 1973 [1974], Water quality criteria, 1972: Washington, D.C., Report of the Committee on Water Quality Criteria, 594 p.

National Technical Advisory Committee to the Secretary of the Interior, 1968, Water quality criteria: U.S. Government Printing Office, 234 p. 
Nichols, P. H., 1964, The remaining frontiers for exploration in northeast Texas: Transactions of the Gulf Coast Association of Petroleum Geologists, v. 14, p. 7-22.

Railroad Commission of Texas, 1952, Saltwater injection in the East Texas Field in $A$ survey of secondary recovery and pressure maintenance operations in Texas to 1952: Engineering Department, p. 91-96. 1981, A survey of secondary and enhanced recovery operations to 1980: Bulletin 80, $544 \mathrm{p}$. 1981, 0il and gas annual production by active fields, 1980: $0 i 1$ and Gas Division, $666 \mathrm{p}$.

Sellards, E. H., Adkins, W. S., and Plummer, F. B., 1932, The geology of Texas, Volume 1, Stratigraphy: University of Texas, Bureau of Economic Geology Bullet in 3232, 1007 p.

Sellards, E. H., and Hendricks, L., 1946, Structural map of Texas, third edition: University of Texas, Bureau of Economic Geology.

Stenzel, H. B., 1953, The geology of Henrys Chapel quadrangle, northeastern Cherokee County, Texas: University of Texas, Bureau of Economic Geology Publication 5305:

Sundstrom, R. W, Hastings, W. W., and Broadhurst, W. L., 1948, Public water supplies in eastern Texas: U.S. Geological Survey Water-Supply Paper $1047,285 \mathrm{p}$.

Swenson, H. A., and Baldwin, H. L., 1965, A primer on water quality: Washington, D.C., U.S. Government Printing Office, 27 p.

Texas Water Commission and Texas Water Pollution Control Board, 1963, A statistical analysis of data on oil-field brine production and disposal in Texas for the year 1961, from an inventory conducted by the Railroad Commission of Texas: Railroad Commission of Texas Distribution 6, v. 1, 327 p.

Theis, C. V., 1935, The relation between the lowering of the piezometric surface and the rate and duration of discharge of a well using ground-water storage: American Geophysical Union, Transactions of 16 th annual meeting, pt. 2, p. 519-524.

Turner, S. F., 1932, Ground-water conditions in East Texas 0il Field: U.S. Geological Survey open-file report, $18 \mathrm{p}$.

U.S. Department of Commerce, Bureau of Census, 1980, United States census of population, 1980; characteristics of the population, Texas: v. 1, pt. 45.

U.S. Environmental Protection Agency, 1976, National interim primary drinking water regulations: Office of Water Supply, EPA-570/9-76-003, $159 \mathrm{p}$.

1977a, Quality criteria for water, 1976: U.S. Government Printing Office, $256 \mathrm{p}$.

1977b, National secondary drinking water regulations: Federal Register, v. 42, no. 62, pt. I, p. 17143-17147.

1979, National secondary drinking water regulations: Federal Register, v. 44 , no. 140 , p. 42196-42202.

U.S. Public Health Service, 1962, Public Health Service drinking-water standards: Public Health Service Publication 956, 61 p.

U.S. Salinity Laboratory Staff, 1954, Diagnosis and improvement of saline and alkaline soils: U.S. Department of Agriculture Handbook 60, 160 p. University of Texas, Bureau of Economic Geology, 1965, Geologic atlas of Texas, Tyler sheet: Austin, Texas.

1968, Geologic atlas of Texas, Palestine sheet: Austin, Texas.

von Hake, C. A., 1977, Earthquake history of Texas: U.S. Geological Survey Earthquake Information Bulletin, v. 9, no. 3, p. 30-32. 
Wenzel, L. K., 1942, Methods for determining permeability of water-bearing material with special reference to discharging-well methods: U.S. Geological Survey Water-Supply Paper 887, $192 \mathrm{p}$.

Wilcox, L. V., 1955, Classification and use of irrigation waters: U.S. Department of Agriculture Circular 969, 19 p.

Wilcox, L. V., Blair, G. Y., and Bower, C. A., 1954, Effect of bicarbonate on suitability of water for irrigation: Soil Science, v. 77, no. 4, p. 259266.

Winslow, A. G., and Kister, L. R., Jr., 1956, Saline water resources of Texas: U.S. Geological Survey Water-Supply Paper 1365, $105 \mathrm{p}$. 
SUPPLEMENTAL INFORMATION

$-64-$ 


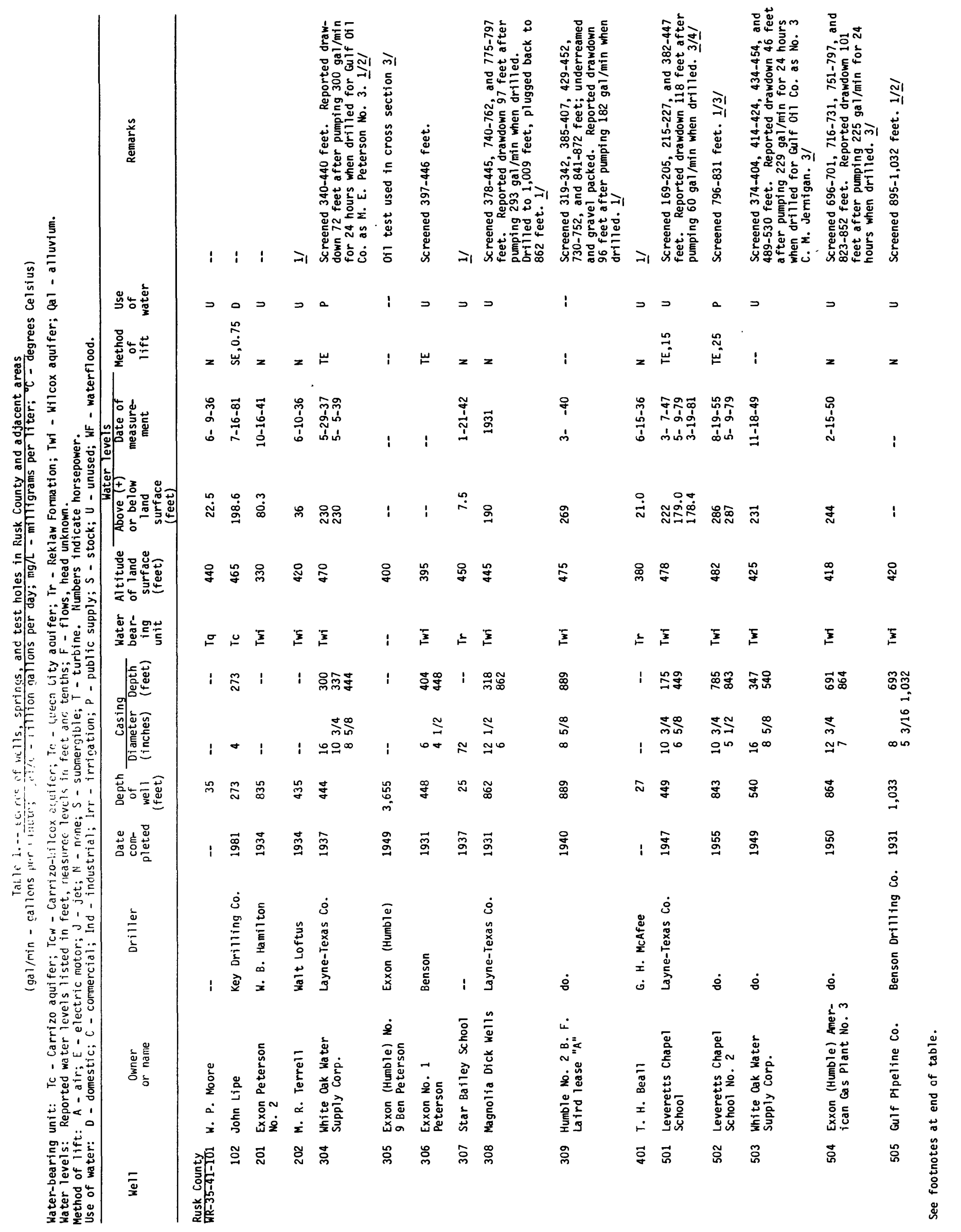




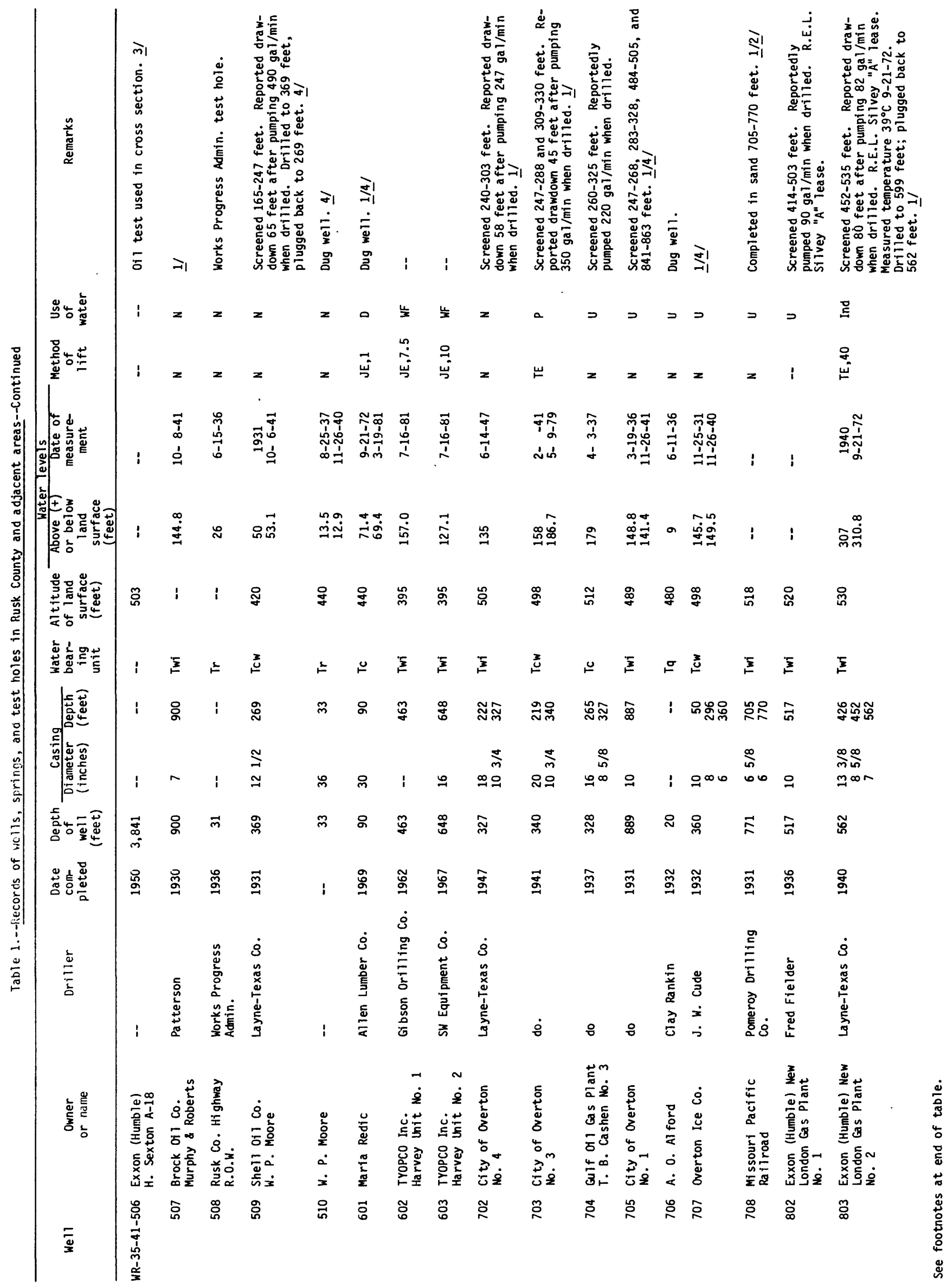




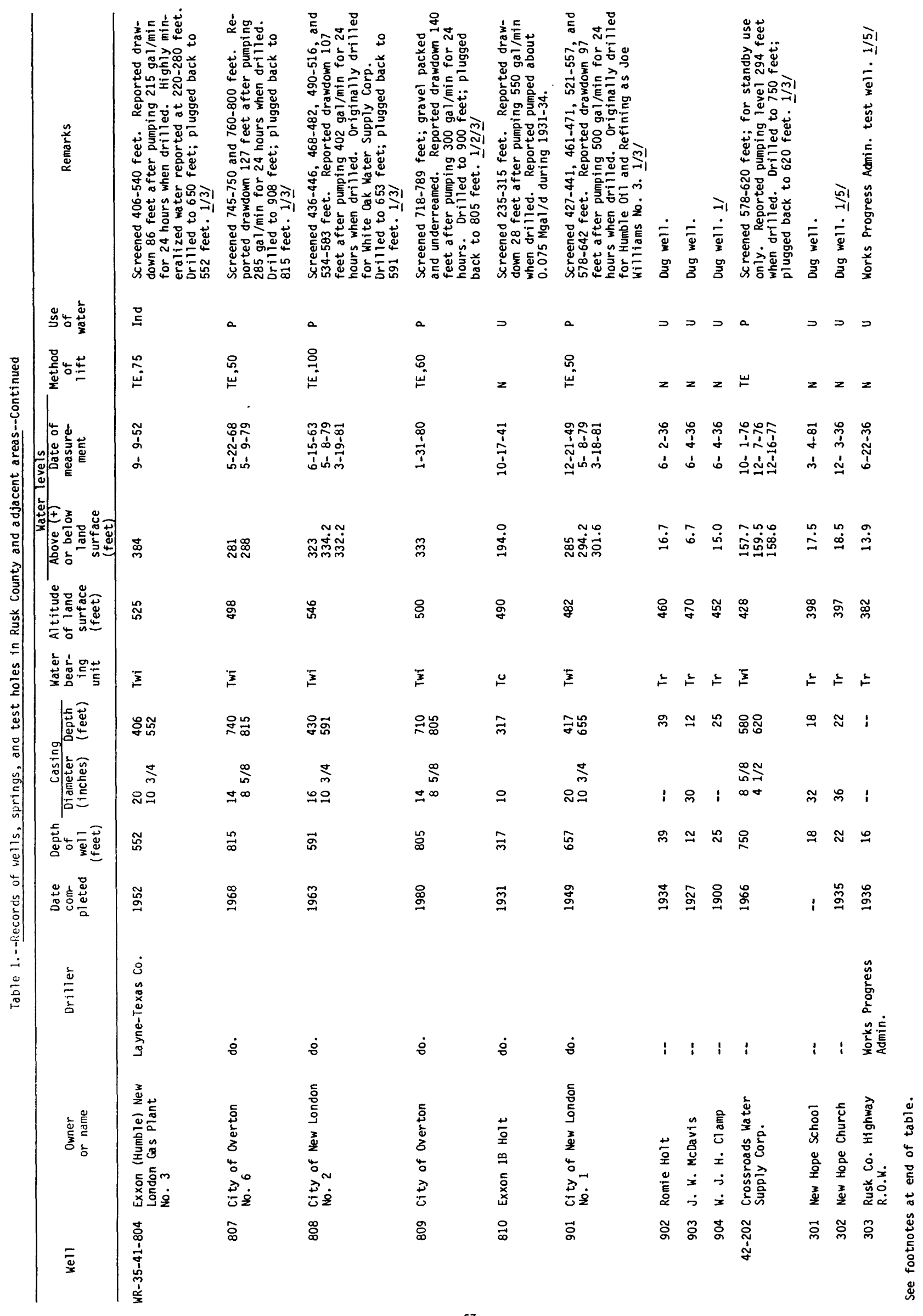




\begin{tabular}{|c|c|c|c|c|c|c|c|c|c|c|c|c|c|c|c|c|c|c|}
\hline 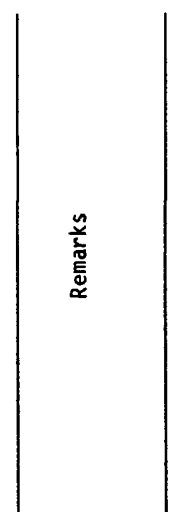 & 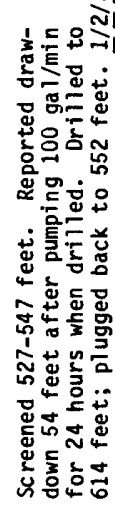 & $\begin{array}{l}\text { को } \\
\dot{\bar{\Phi}} \\
\text { इे } \\
\text { oे }\end{array}$ & $\dot{8}$ & $\dot{8}$ & 8 & & 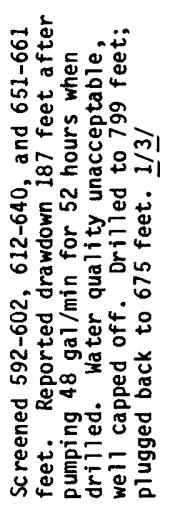 & & 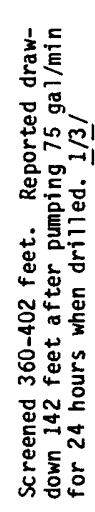 & 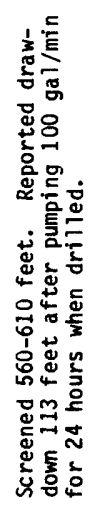 & 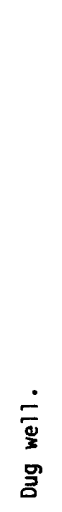 & $\dot{8}$ & 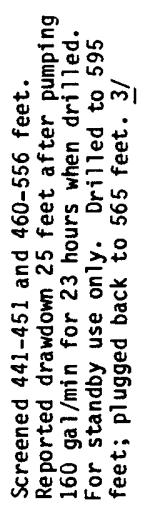 & 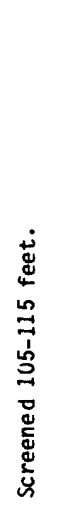 & 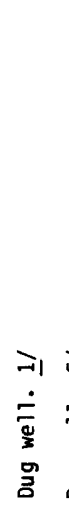 & 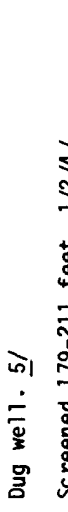 & 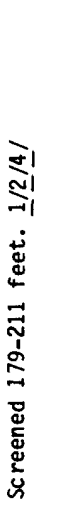 & $\stackrel{+1}{ \pm 1}$ \\
\hline 崩出蒡 & $a$ & $=$ & $=$ & $D$ & & i & $=$ & 0 & a & a & $\Xi$ & $=$ & $a$ & 0 & & $\Rightarrow$ & 0 & 0 \\
\hline 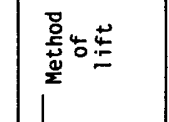 & 岕 & $z$ & $z$ & $z$. & $z$ & $i$ & $z$ & 山 & 号 & 岕 & 岕 & $z$ & 芯 & 岕 & 山 & $=\stackrel{9}{4}$ & 孞 & 山 \\
\hline 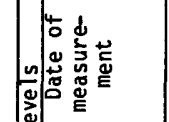 & 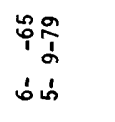 & 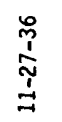 & 拉 & $\begin{array}{l}\stackrel{0}{0} \\
\dot{y} \\
\dot{y}\end{array}$ & 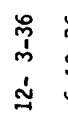 & 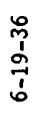 & 号 & 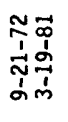 & 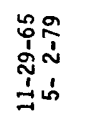 & 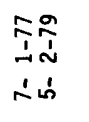 & \begin{tabular}{l}
$\overrightarrow{0}$ \\
0 \\
\multirow{N}{N}{} \\
m
\end{tabular} & 吕 & $\begin{array}{l}\overrightarrow{0} \\
\dot{1} \\
\dot{m} \\
\dot{m}\end{array}$ & 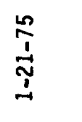 & & 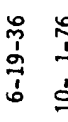 & 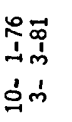 & 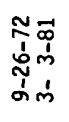 \\
\hline 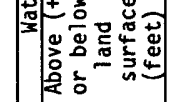 & 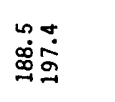 & $\overrightarrow{\text { N }}$ & $\stackrel{\circ}{\leftrightarrows}$ & \llcorner & $\stackrel{\circ}{9}$ & ì & 을 & $\begin{array}{l}\text { mĩ } \\
\text { ஸे }\end{array}$ & ஓ्व & มี & $\stackrel{\leftrightarrow}{\leftrightarrow}$ & $\stackrel{\sim}{\infty}$ & مُ & ○ & $\stackrel{\infty}{\dot{N}}$ & $\stackrel{+}{\circ}$ & نَّ & 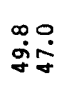 \\
\hline 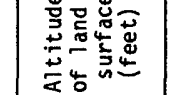 & $\stackrel{乛}{\Im}$ & 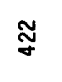 & 品 & స్ల & 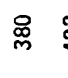 & $\tilde{\Xi}$ & $\tilde{\widetilde{g}}$ & g & $\tilde{y}$ & $\mathfrak{z}$ & 足 & ఫి & ஓ्ల్ & $\vec{\sigma}$ & ల్లి & థ్లి & 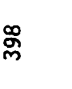 & 8 \\
\hline 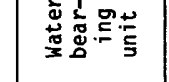 & $\underline{\underline{E}}$ & 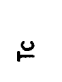 & $\approx$ & 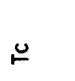 & 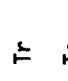 & 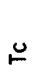 & $\underline{\xi}$ & 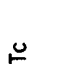 & $\Xi$ & $\underline{\underline{z}}$ & $\leftrightarrows$ & 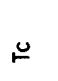 & $\underline{I}$ & $\stackrel{\longleftarrow}{ }$ & & 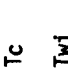 & $\overline{\underline{z}}$ & 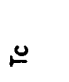 \\
\hline 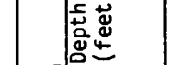 & స్ర్య & ¿ & i & 茴 & $\vec{m}$ & 요 & $\stackrel{\mathscr{0}}{\mathfrak{6}} \stackrel{2}{6}$ & 6 & ద్లో & 융음 & $\stackrel{\sim}{2}$ & $\stackrel{m}{m}$ & 荨号 & $\stackrel{\Omega}{\Xi}$ & i & 1 z & $\vec{\sim}$ & is \\
\hline 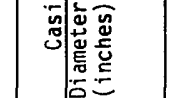 & $\begin{array}{l}\infty=5 \\
\substack{\infty \\
\infty}\end{array}$ & $\stackrel{m}{\infty}$ & i & I & $\stackrel{\circ}{\circ}$ & ; & 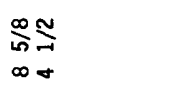 & ల్ల & $\begin{array}{l}\infty \\
\substack{\infty \\
\infty} \\
\infty \\
0\end{array}$ & $\begin{array}{l}\infty \\
\substack{\infty \\
\infty \\
\infty} \\
\infty\end{array}$ & ᄋ్ల & i & or $^{-}$ & $\sigma$ & ; & 10 & $\sigma$ & 이 \\
\hline 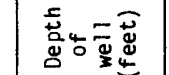 & 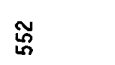 & స & $\overrightarrow{\text { N }}$ & 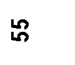 & $\vec{m}$ & 요 & தे & 6 & $\tilde{q}$ & $\stackrel{ }{0}$ & $\stackrel{\sim}{2}$ & $\stackrel{m}{m}$ & 总 & $\cong$ & $\stackrel{\sim}{\sim}$ & న & స్సి & in \\
\hline 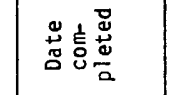 & $\stackrel{\circ}{\leftrightarrows}$ & i & & @ొ & $\vec{\Xi}$ & $\stackrel{\circ}{\Xi}$ & $\stackrel{ٌ}{\$}$ & 怘 & $\stackrel{\circ}{ٌ}$ & 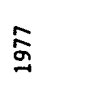 & ॐ̆ & $\stackrel{\infty}{9}$ & 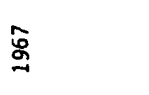 & $\frac{20}{9}$ & & ี ڤे & స్ & $\stackrel{P}{9}$ \\
\hline$\frac{\grave{d}}{\frac{\delta}{\delta}}$ & 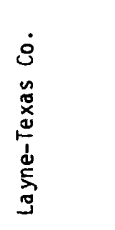 & $i$ & $i$ & 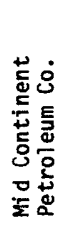 & i & i & 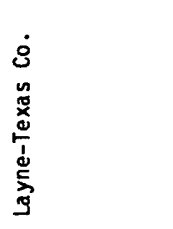 & 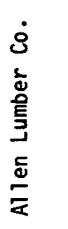 & 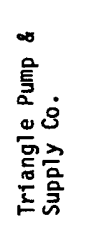 & 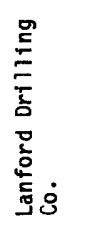 & $\frac{\grave{0}}{\frac{\partial}{2}}$ & i & 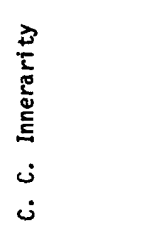 & 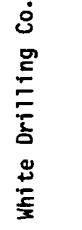 & 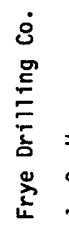 & 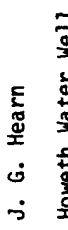 & 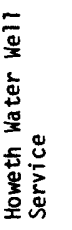 & 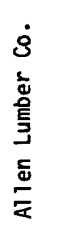 \\
\hline 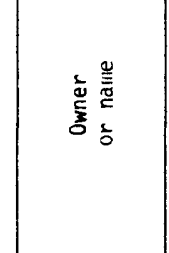 & 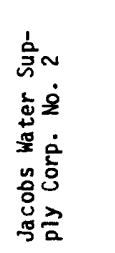 & 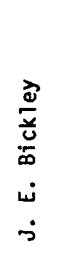 & 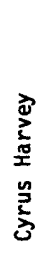 & 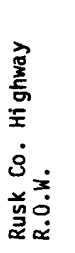 & $\begin{array}{l} \\
\stackrel{0}{0} \\
\stackrel{0}{2} \\
\dot{0} \\
\dot{0}\end{array}$ & 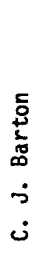 & 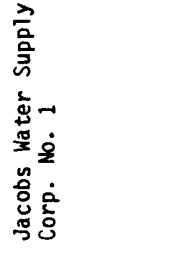 & 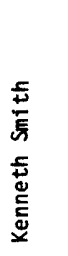 & 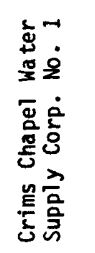 & 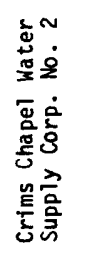 & 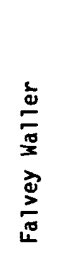 & 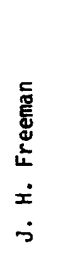 & 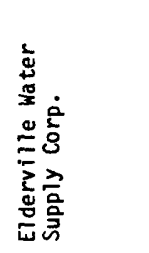 & 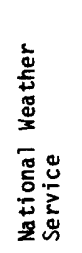 & 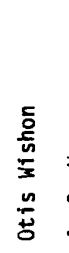 & 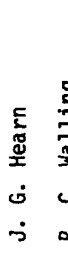 & 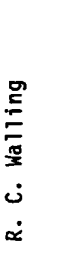 & 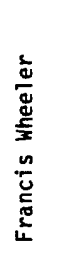 \\
\hline$\overline{\bar{\Xi}}$ & 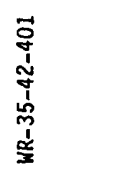 & $\tilde{\xi}$ & $\stackrel{m}{q}$ & $\overrightarrow{\mathrm{B}}$ & $\vec{\Delta}$ & ธ & $\vec{D}$ & $\vec{\Phi}$ & $\overrightarrow{8}$ & ฉั & \%̊ & ఫั & 岕 & $\overrightarrow{\tilde{m}}$ & & $\vec{q}$ & 䓟 & $\overrightarrow{\mathrm{s}}$ \\
\hline
\end{tabular}




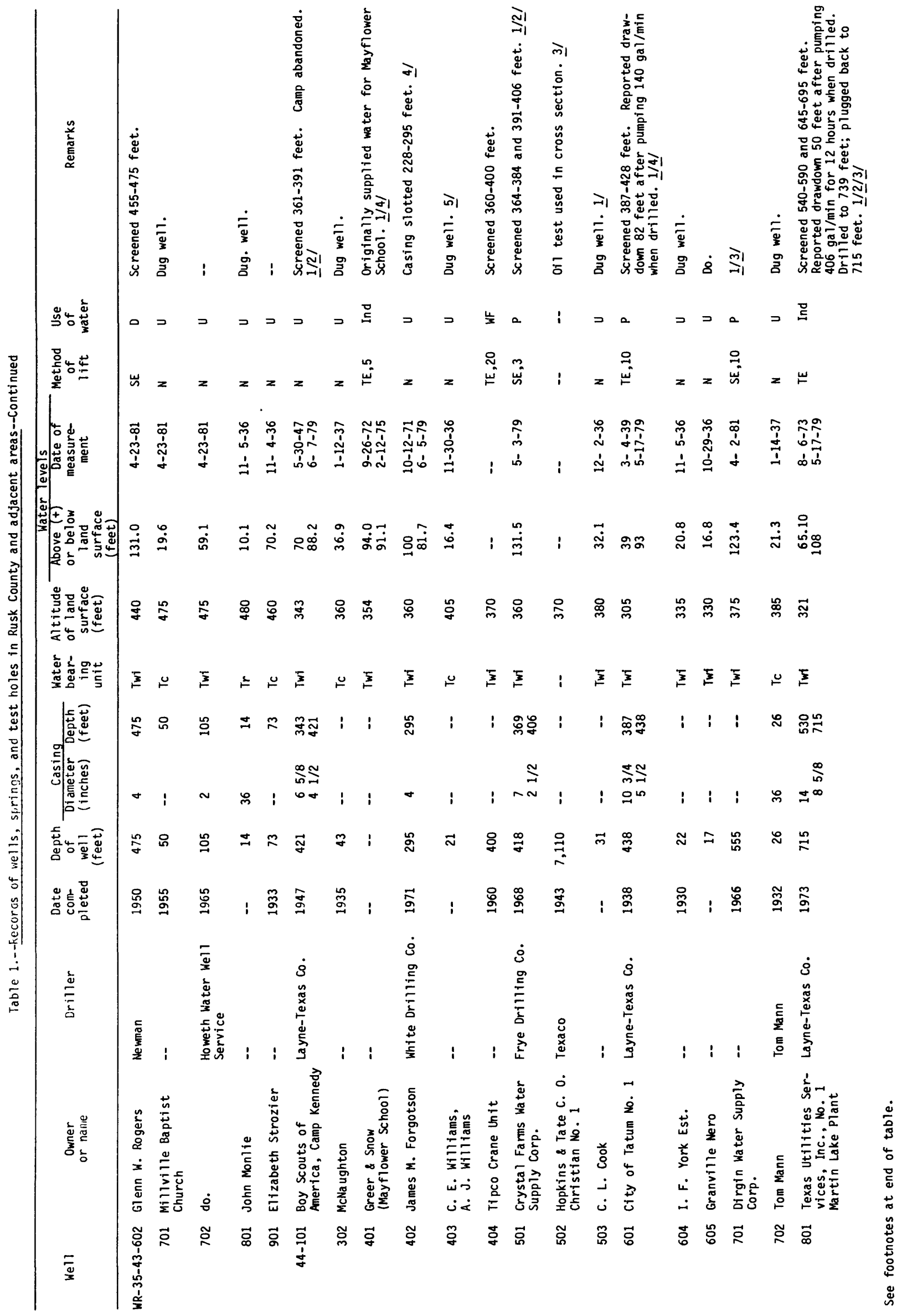




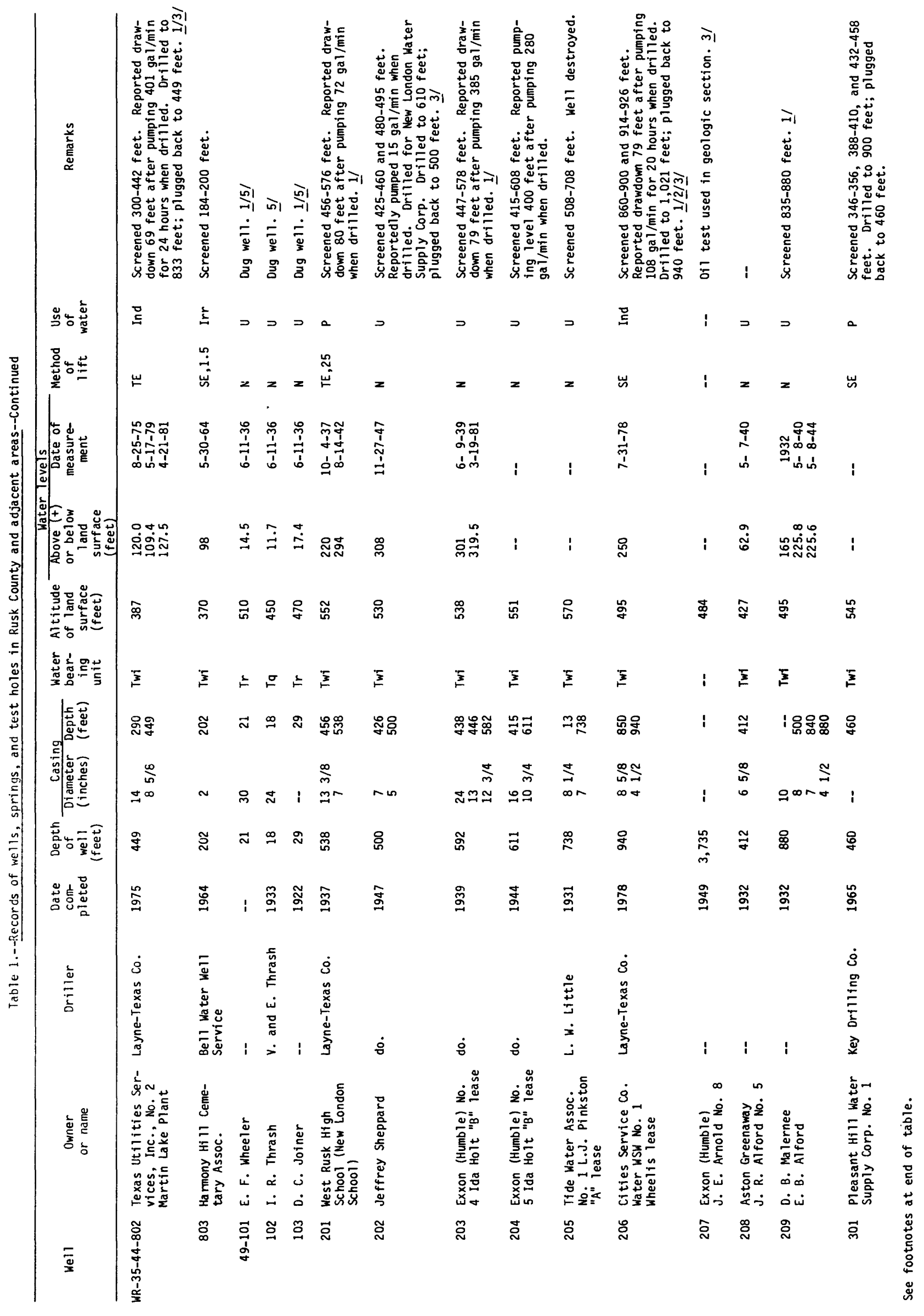




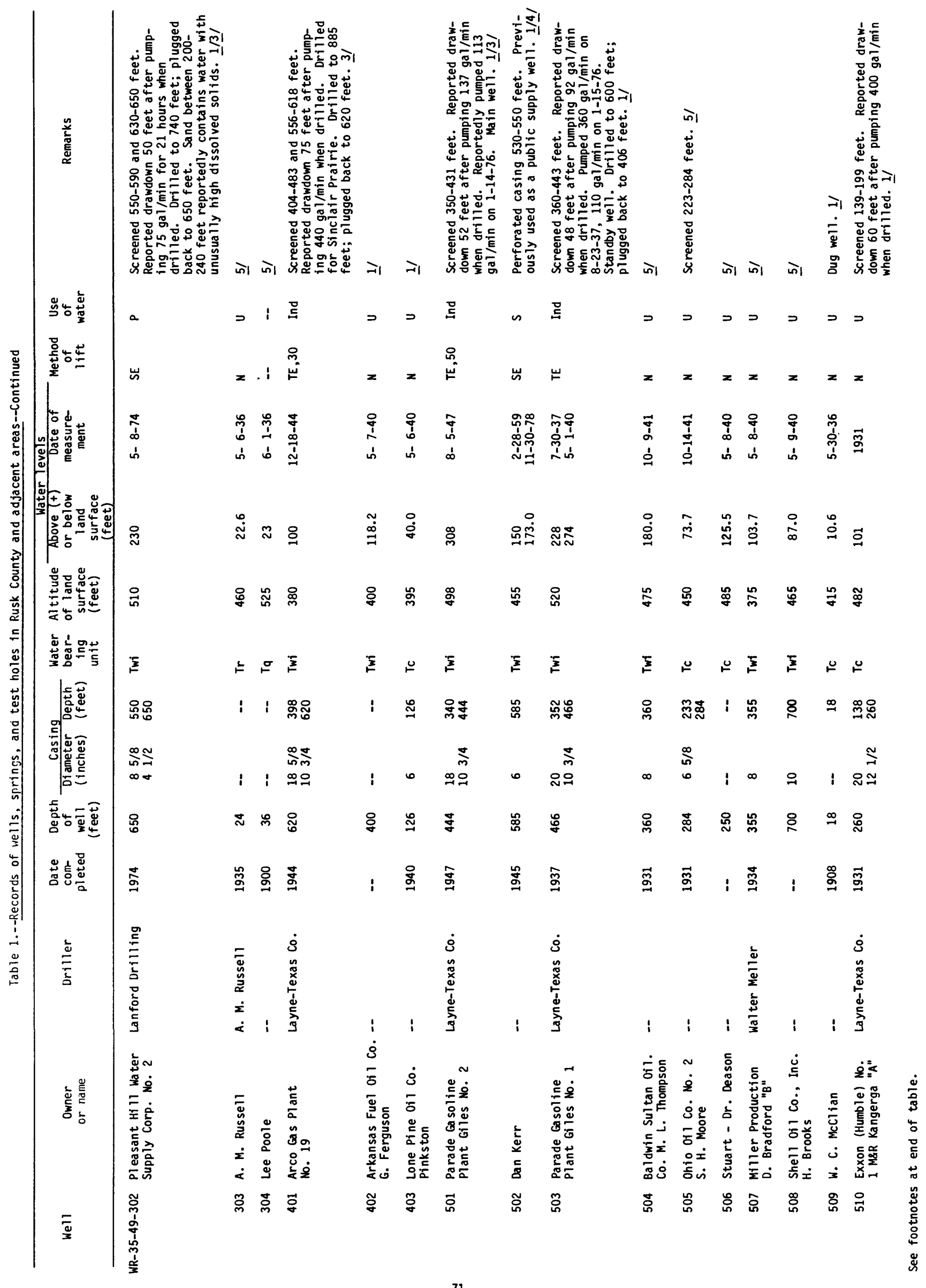




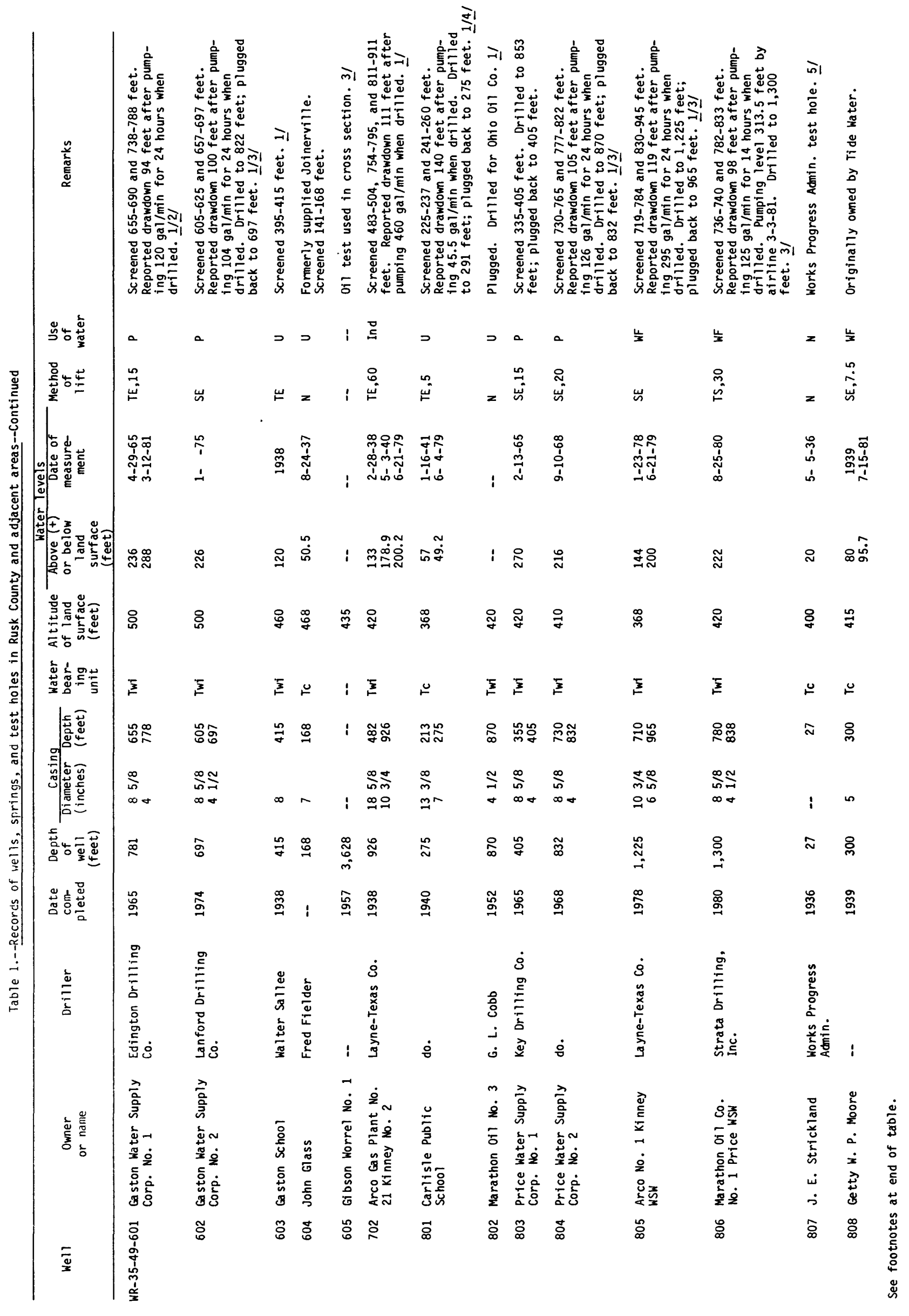




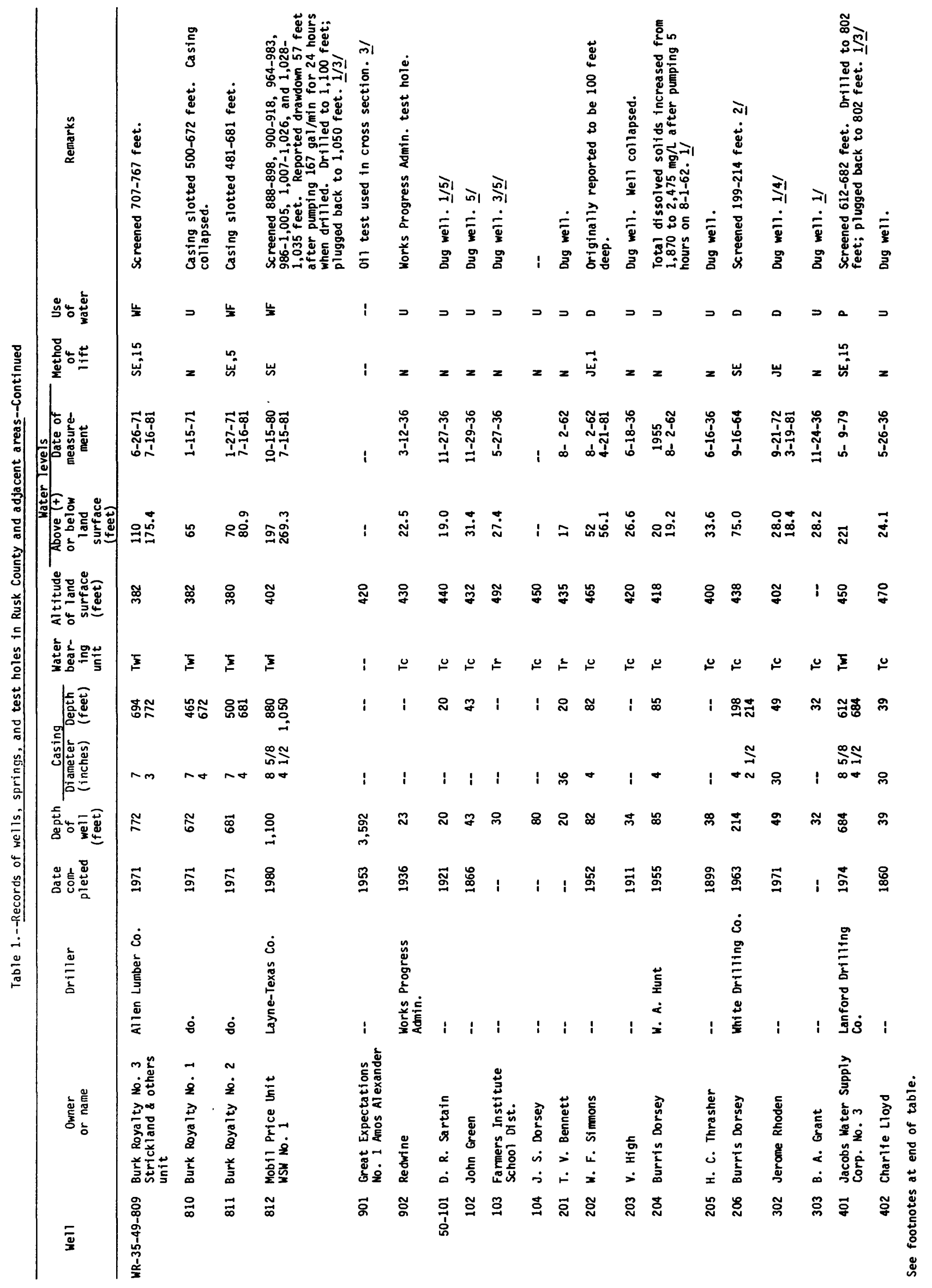




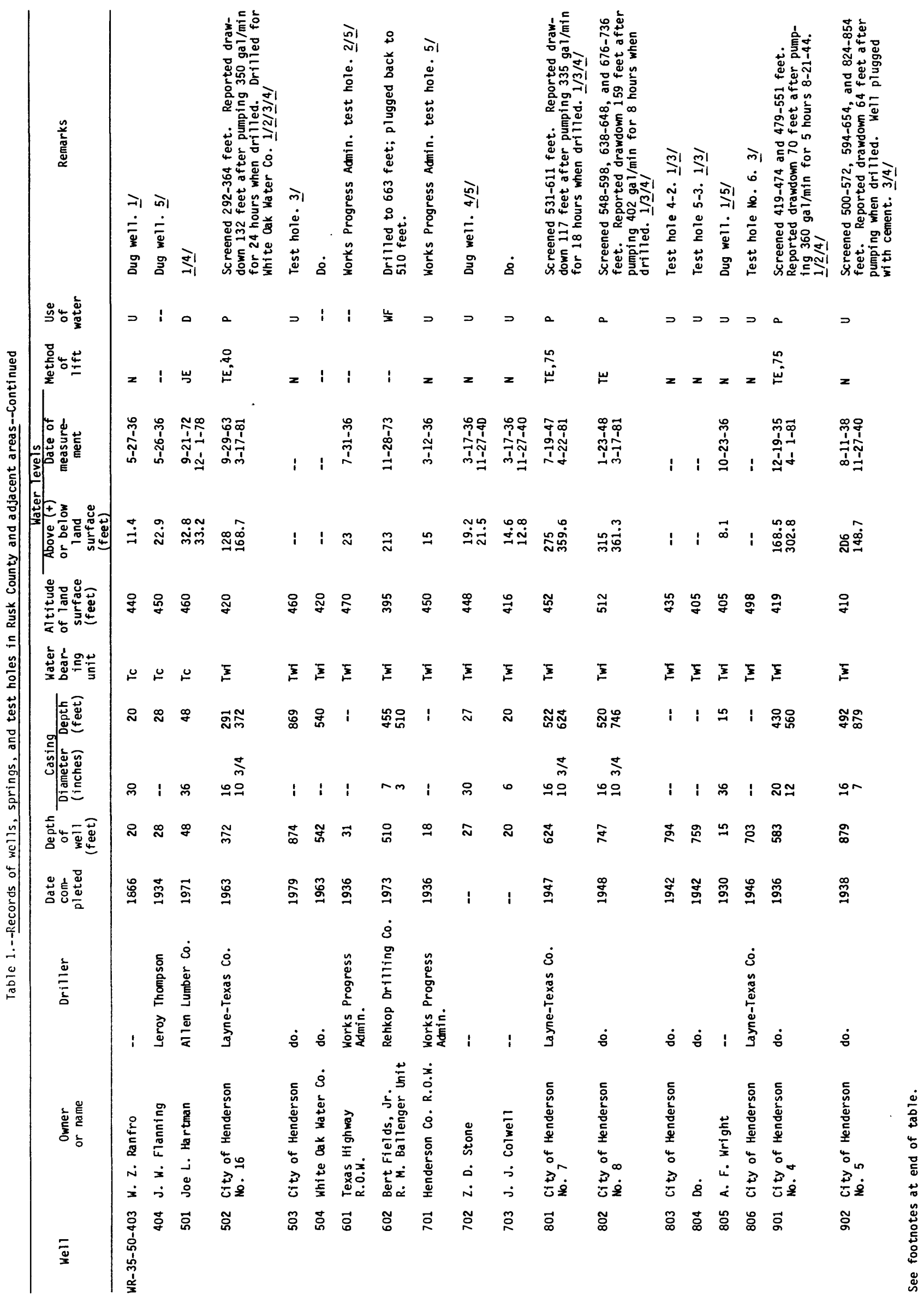




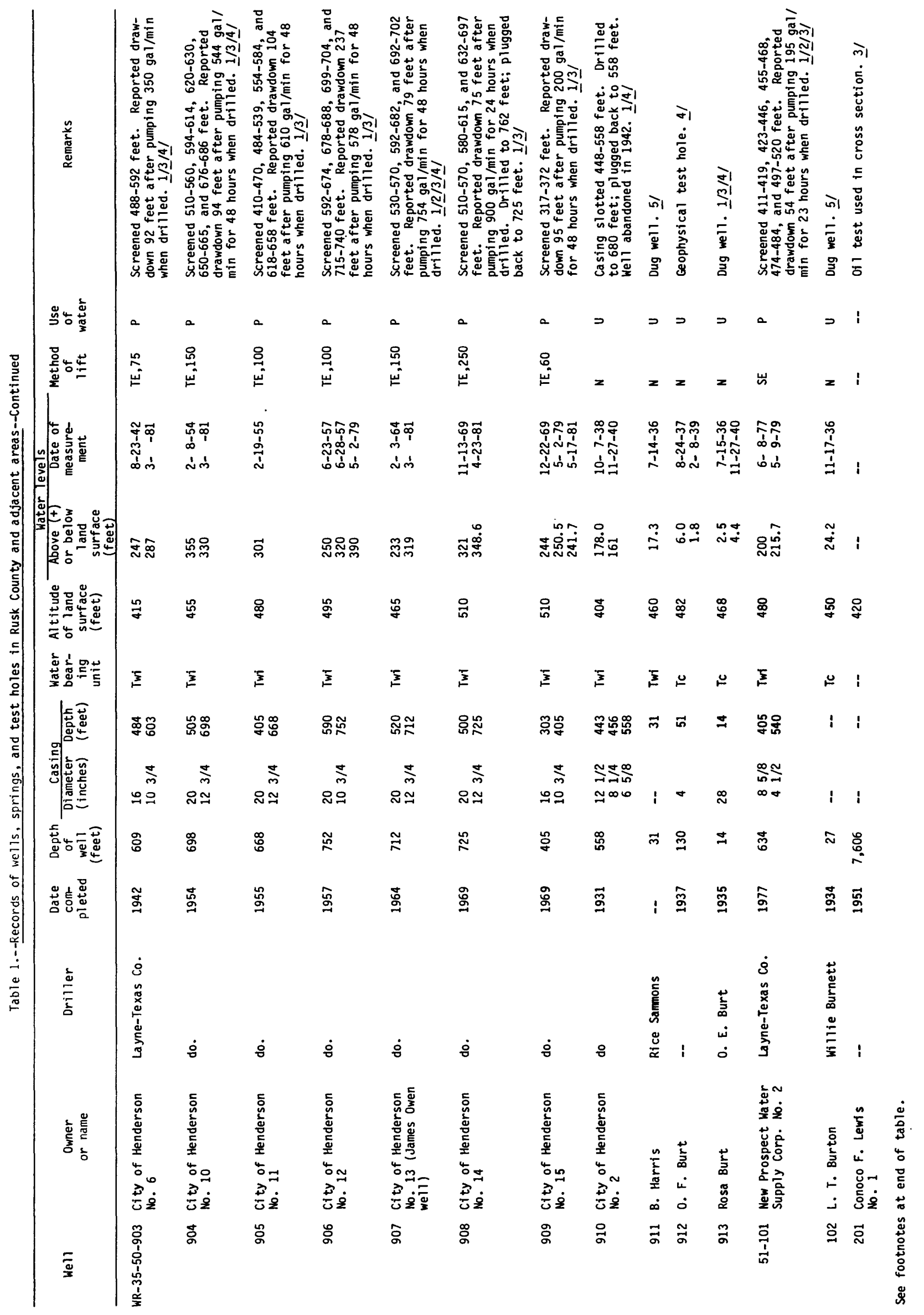




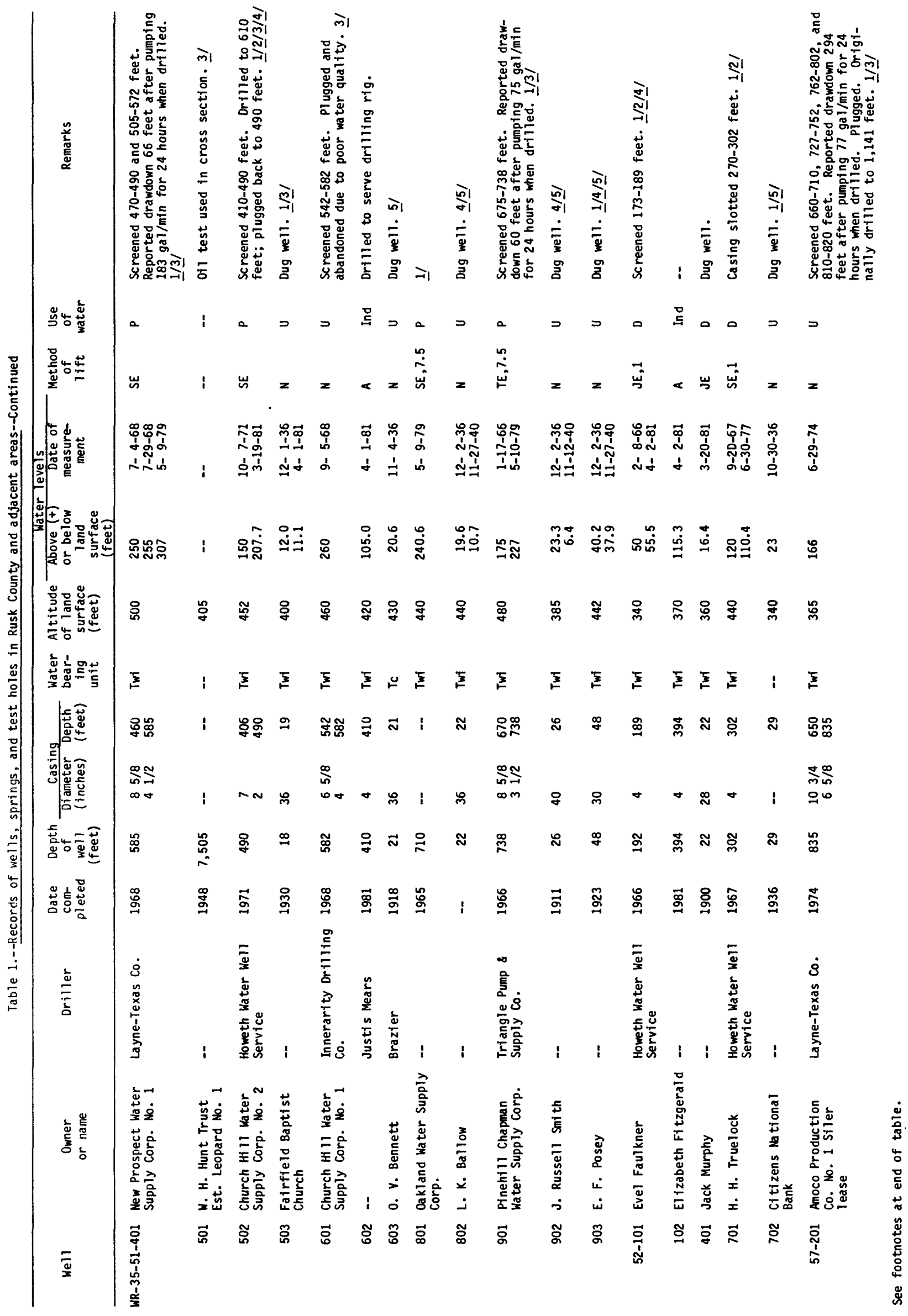




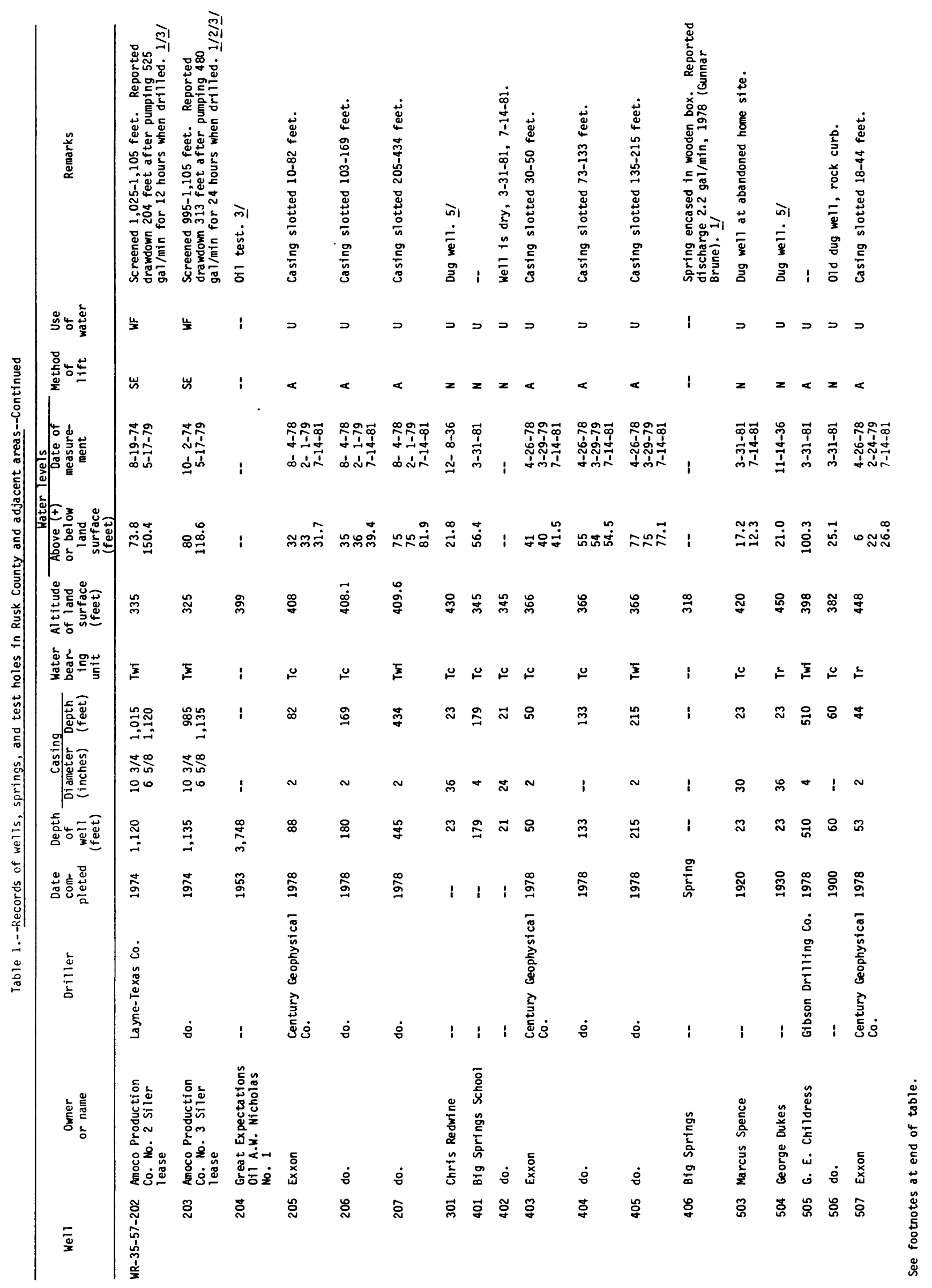




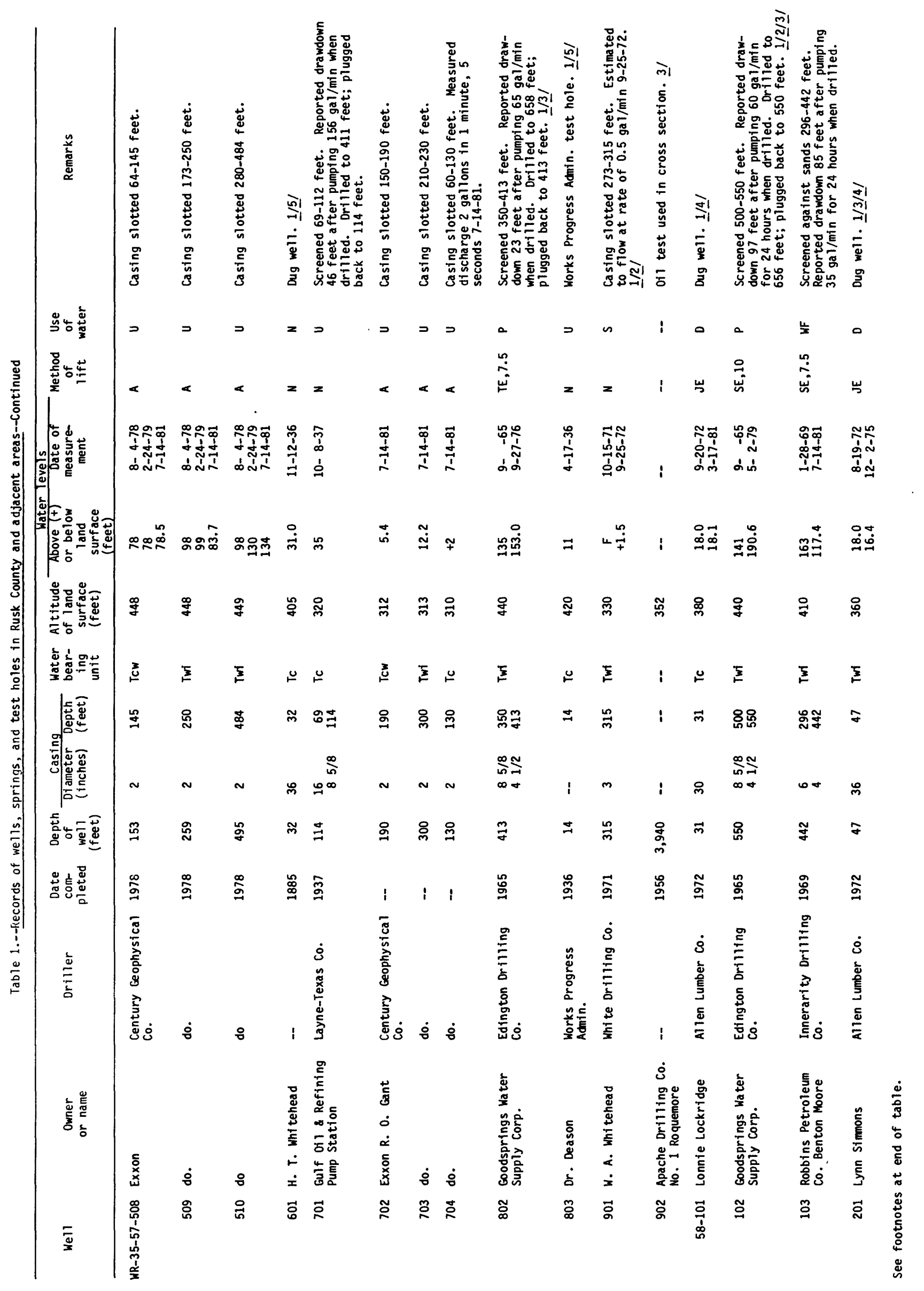




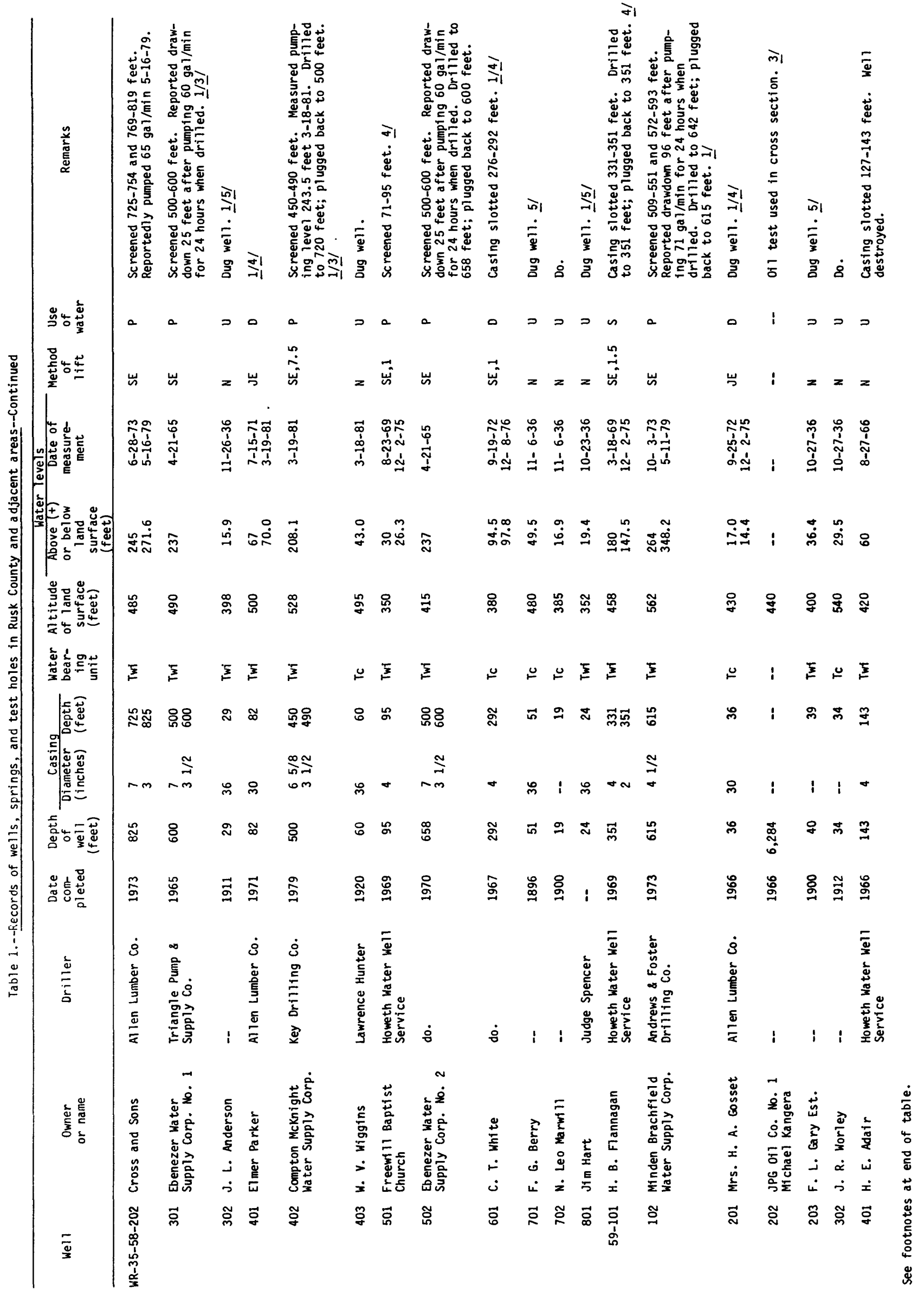




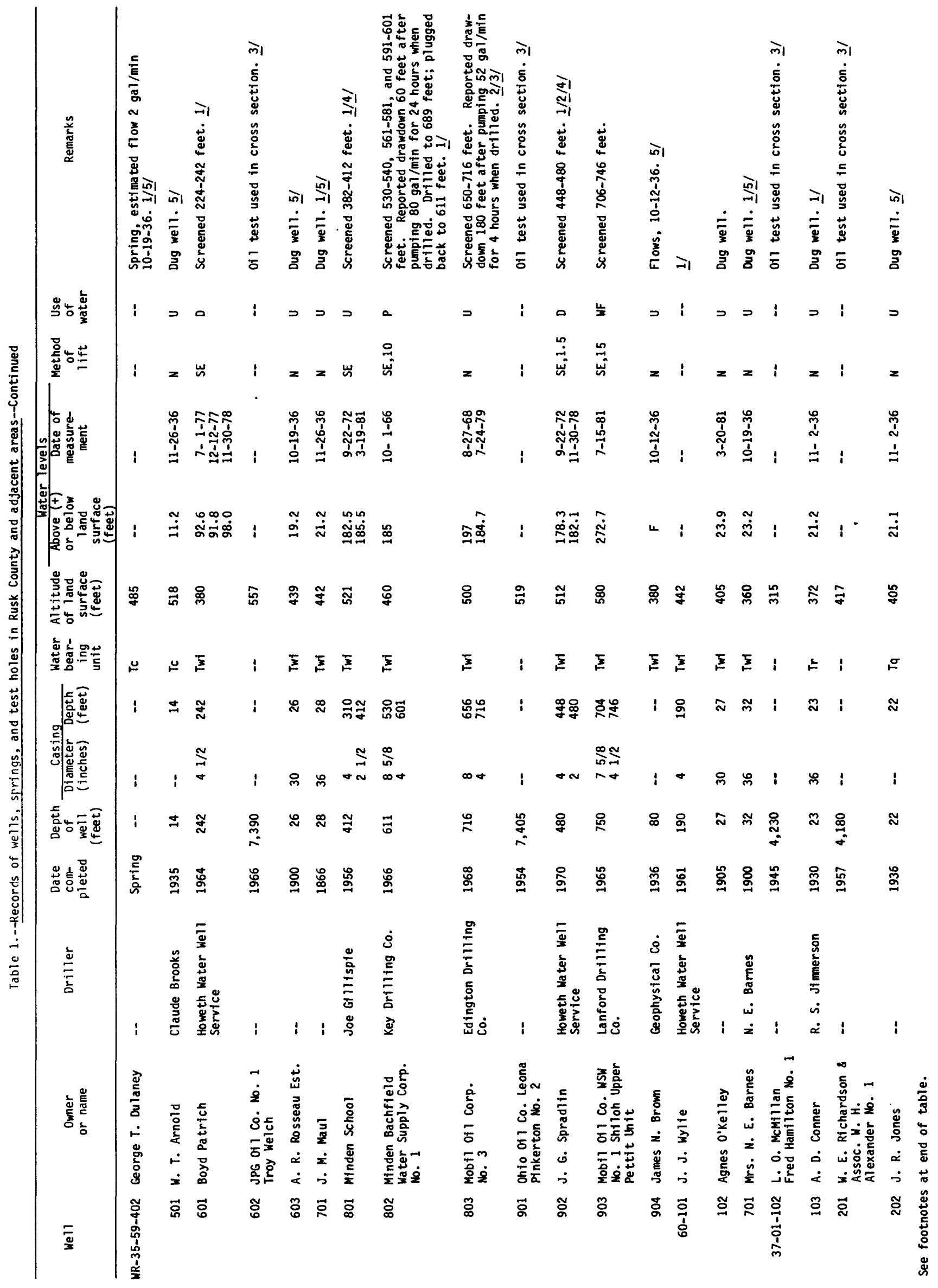




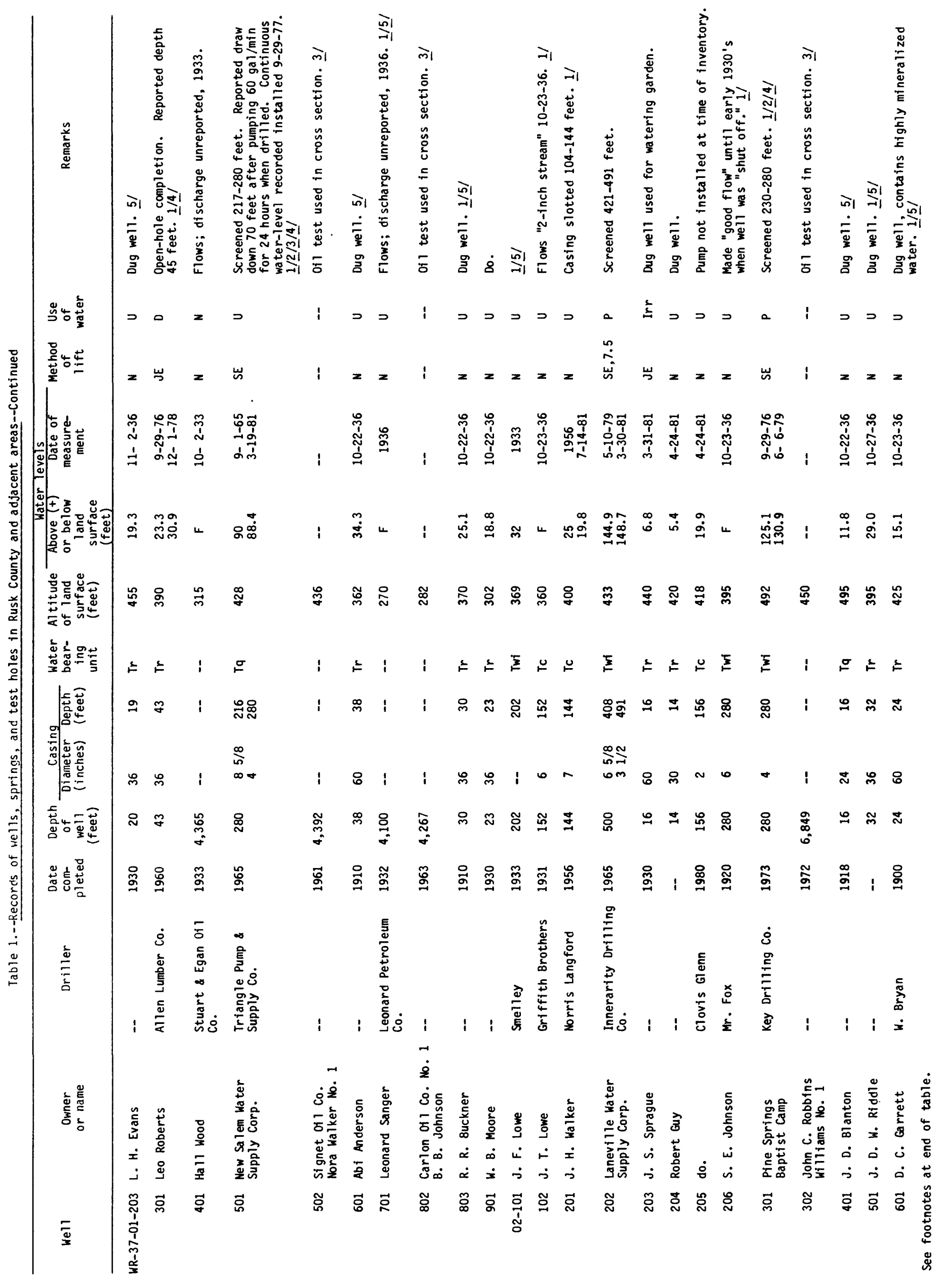




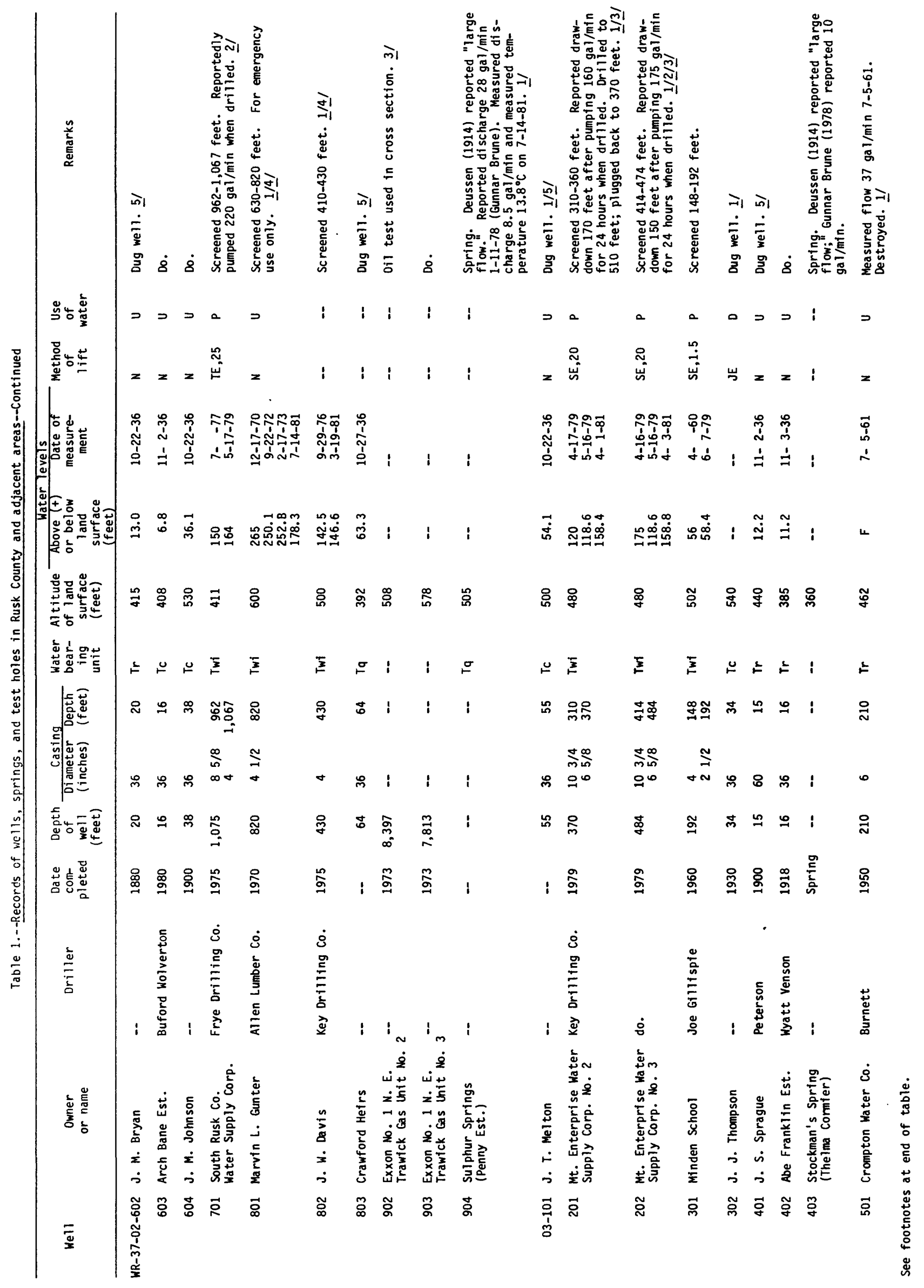




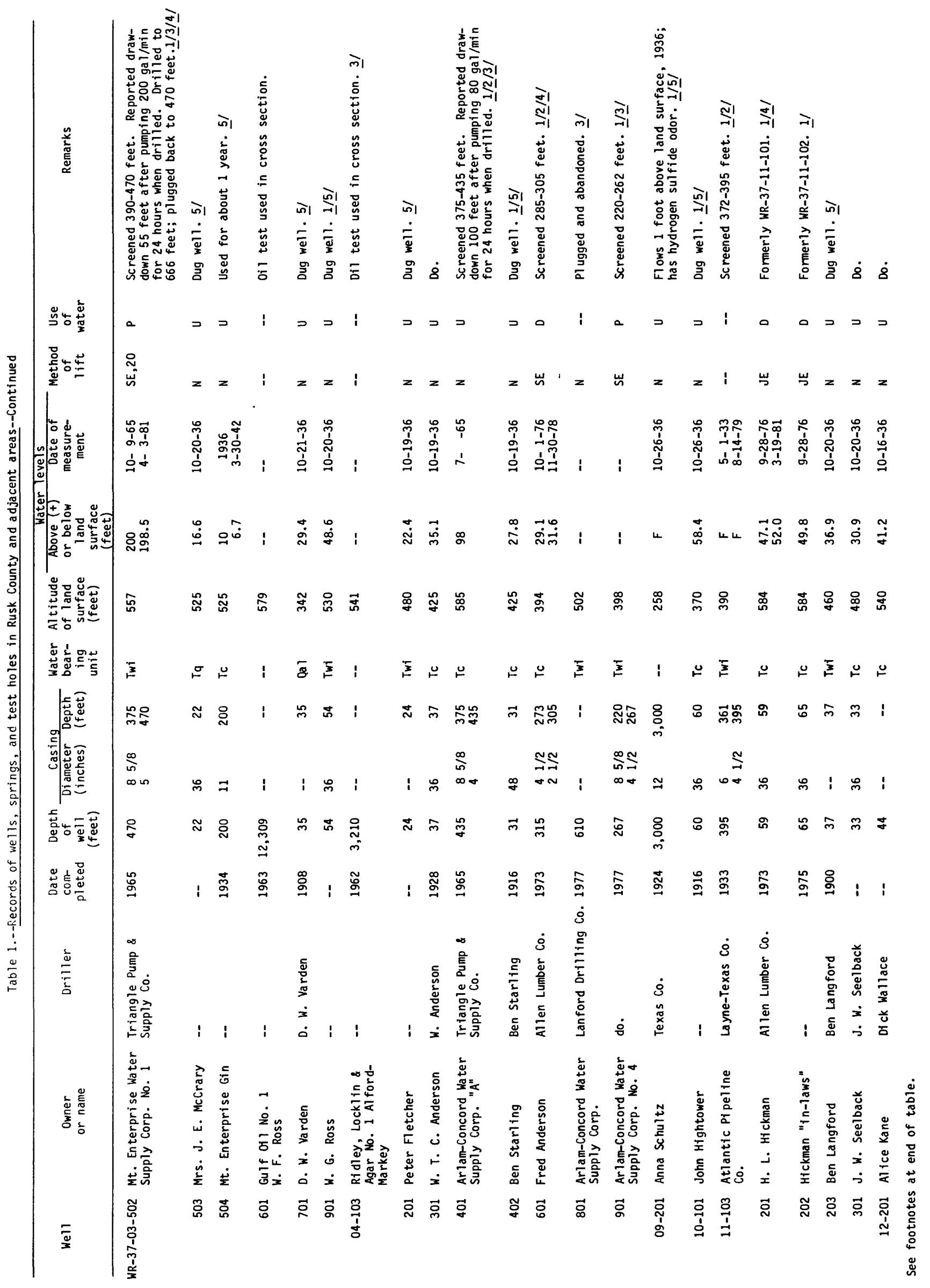




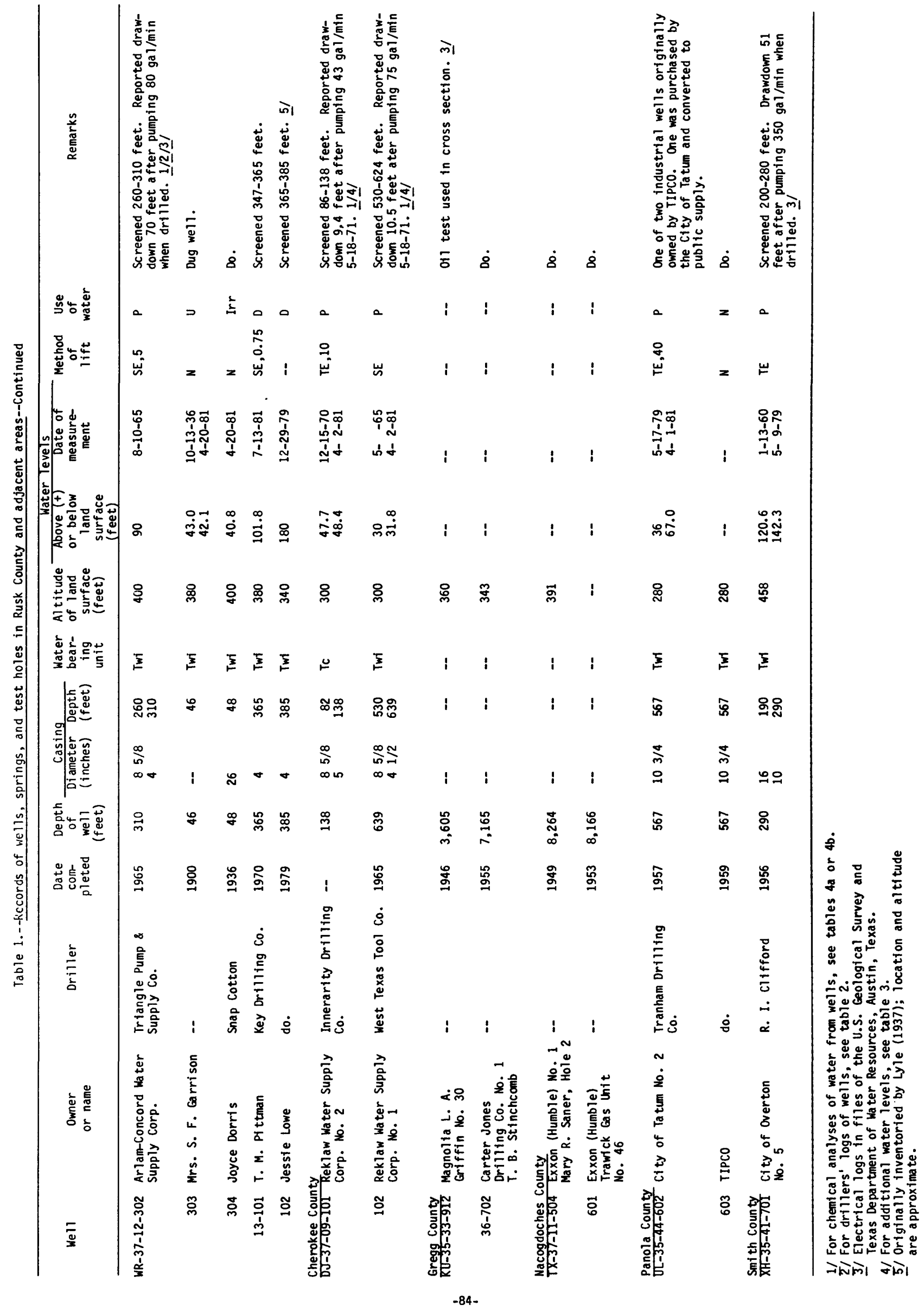


Table 2.--Drillers' logs of selected wells in Rusk County

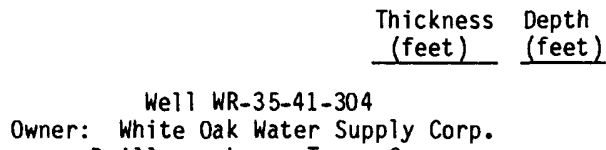

Surface soil

$\mathrm{Cl}$ ay

Sand

Clay

Shale

Sand

Shale

Rock

Shale

Sand

Shale

Rock

Shale

Sandy shale

Rock

Shale and boulders

Shale and layers of sand

Hard shale

Shale and lignite

Sand

Sandy shale

Sand

Sandy shale

Sand

Shale

11 WR-35-41-505

Owner: Gulf Pipeline Co. Driller: Benson Drilling Co.

$\begin{array}{lll}\text { Surface soil } & 20 & 20 \\ \text { Sand } & 25 & 45 \\ \text { Shale } & 13 & 58 \\ \text { Sandy shale } & 17 & 75\end{array}$

\section{Thickness Depth (feet) (feet)}

Well WR-35-41-505--Cont.

\begin{tabular}{|c|c|}
\hline Rock & 1 \\
\hline Sticky shale & 27 \\
\hline Rock & 2 \\
\hline Sand and boulders & 9 \\
\hline Hard sand rock & 9 \\
\hline Rock & 2 \\
\hline Sandy shale & 8 \\
\hline Rock & 1 \\
\hline Sandy shale & 7 \\
\hline Rock & 1 \\
\hline Sand & 64 \\
\hline Sandy shale & 14 \\
\hline Hard shale & 7 \\
\hline Shale and boulders & 23 \\
\hline Hard sand rock & 15 \\
\hline Sand & 15 \\
\hline Lignite and sand streaks & 10 \\
\hline Lignite & 23 \\
\hline Sandy shale & 23 \\
\hline Lignite & 4 \\
\hline Sandy shale & 48 \\
\hline Hard sand rock & 6 \\
\hline Shale & 14 \\
\hline Sandy shale & 10 \\
\hline Sand and shale & 112 \\
\hline Gumbo & 10 \\
\hline Shale & 20 \\
\hline Sticky shale & 20 \\
\hline Packsand & 8 \\
\hline Gray sand & 17 \\
\hline Hard Sand & 25 \\
\hline Sand & 60 \\
\hline
\end{tabular}


Table 2.--Drillers' logs of selected wells in Rusk County--Continued

$$
\begin{array}{ll}
\begin{array}{c}
\text { Thickness } \\
\text { (feet) }
\end{array} \text { (feet) } \\
\hline
\end{array}
$$

Well WR-35-41-505--Cont.

$\begin{array}{lrr}\text { Rock } & 4 & 694 \\ \text { Gumbo } & 10 & 704 \\ \text { Sandy shale } & 64 & 768 \\ \text { Sand and lignite } & 22 & 790 \\ \text { Lignite } & 16 & 806 \\ \text { Sand } & 12 & 818 \\ \text { Broken sand and lignite } & 32 & 850 \\ \text { Gumbo } & 5 & 855 \\ \text { Rock } & 5 & 860 \\ \text { Sand and lignite } & 20 & 880 \\ \text { Rock } & 6 & 886 \\ \text { Sand } & 144 & 1,030 \\ \text { Gumbo } & 3 & 1,033\end{array}$

WR-35-41-708

Owner: Missouri Pacific Railroad

Driller: Pomeroy Drilling Co.

Surface clay and sand

Water sand

Clay

Packed sand and boulders

Clay

Rock

Packed sand

Sand and shale

Shale

Rock

Packed sand

Hard sandy shale

Rock

Sand and boulders

Sandy shale

Sand

Sand and boulders

$18 \quad 18$

$15 \quad 50$

$27 \quad 77$

$34 \quad 111$

$2 \quad 113$

$18 \quad 131$

$7 \quad 138$

$15 \quad 153$

2155

$4 \quad 159$

$10 \quad 169$

$1 \quad 170$

$33 \quad 203$

$16 \quad 219$

$30 \quad 249$

$51 \quad 300$
Thickness Depth (feet) (feet)

\begin{tabular}{|c|c|c|}
\hline Fine sand & 10 & 310 \\
\hline Sand and boulders & 17 & 327 \\
\hline Packed sand & 5 & 332 \\
\hline Sand & 13 & 345 \\
\hline Sand and shale & 11 & 356 \\
\hline Sand and boulders & 5 & 361 \\
\hline Hard shale & 10 & 371 \\
\hline Packed sand & 9 & 380 \\
\hline Sand and boulders & 23 & 403 \\
\hline Shale & 14 & 417 \\
\hline Sand and boulders & 23 & 440 \\
\hline Sand and lignite & 20 & 460 \\
\hline Hard shale & 38 & 498 \\
\hline Sand, boulders, and lignite & 32 & 530 \\
\hline Gumbo & 7 & 537 \\
\hline Rock & 1 & 538 \\
\hline Hard shale & 22 & 560 \\
\hline Sand and shale & 20 & 580 \\
\hline Sand and boulders & 20 & 600 \\
\hline Sand and shale & 10 & 610 \\
\hline Sand and boulders & 13 & 623 \\
\hline Shale & 15 & 638 \\
\hline Sand & 5 & 643 \\
\hline Shale & 19 & 662 \\
\hline Hard sand & 22 & 684 \\
\hline Sand & 10 & 694 \\
\hline Packed sand & 11 & 705 \\
\hline Sand & 65 & 770 \\
\hline Gumbo & 1 & 771 \\
\hline
\end{tabular}

Well WR-35-41-708--Cont. 
Table 2.--Drillers' logs of selected wells in Rusk County--Cont inued

Thickness Depth

(feet) (feet)

Well WR-35-41-809

Owner: City of Overton

Driller: Layne-Texas Co.

Topsoil

Red clay

Sand

Shale

Sandy shale and sand streaks

Sand and sandy shale streaks

Sandy shale with sand and shale streaks

Rock

Shale

Rock

Shale

Rock

Sandy shale

Rock

Shale

Lignite

Rock

Sandy shale

Rock

Sandy shale

Rock

Shale

Sand

Rock

Sand

Rock and sandy shale

Sand with lignite streaks

Shale, sandy shale with lignite streaks

Sand

Sand with shale streaks

\begin{tabular}{|c|c|}
\hline 2 & 2 \\
\hline 20. & 22 \\
\hline 3 & 25 \\
\hline 10 & 35 \\
\hline 9 & 44 \\
\hline 10 & 54 \\
\hline 58 & 112 \\
\hline 1 & 113 \\
\hline 6 & 119 \\
\hline 1 & 120 \\
\hline 23 & 143 \\
\hline 1 & 144 \\
\hline 2 & 146 \\
\hline 2 & 148 \\
\hline 6 & 154 \\
\hline 1 & 155 \\
\hline 1 & 156 \\
\hline 1 & 157 \\
\hline 1 & 158 \\
\hline 2 & 160 \\
\hline 1 & 161 \\
\hline 3 & 164 \\
\hline 2 & 166 \\
\hline 1 & 167 \\
\hline 9 & 176 \\
\hline 2 & 178 \\
\hline 18 & 196 \\
\hline 4 & 200 \\
\hline 16 & 216 \\
\hline 7 & 223 \\
\hline
\end{tabular}

Thickness Depth

(feet) (feet)

Well WR-35-41-809--Cont.

Sand
Shale and sandy shale streaks
Rock
Sandy shale with sand and lignite
streaks
Shale, sandy shale with lignite
streaks
Shale with lignite streaks
Sand
Shale, sandy shale with lignite
streaks
Sand, sandy shale with shale
streaks

$\begin{array}{rr}75 & 298 \\ 12 & 310 \\ 1 & 311 \\ 24 & 335 \\ 26 & 361 \\ 63 & 424 \\ 5 & 429\end{array}$

$34 \quad 463$

$\begin{array}{lll}\text { streaks } & 93 & 556\end{array}$

Sandy shale with shale streaks $\quad 44 \quad 600$

$\begin{array}{lll}\text { Shale } & 8 & 608\end{array}$

$\begin{array}{lll}\text { Sandy with shale streaks } & 9 & 617\end{array}$

Rock $3 \quad 620$

Shale $\quad 12 \quad 632$

Sand $\quad 2 \quad 634$

Sandy shale $\quad 3 \quad 637$

Shale and sandy shale $\quad 29 \quad 666$

Sand with shale streaks $\quad 3 \quad 669$

Sandy shale with shale layers $\quad 20 \quad 689$

Hard shale $\quad 1 \quad 690$

Rock 11691

Hard shale $\quad 6 \quad 697$

Sand and sandy shale $\quad 105 \quad 802$

$\begin{array}{lll}\text { Shale with sandy streaks } & 6 & 808\end{array}$

$\begin{array}{lll}\text { Shale with lignite streaks } & 24 & 832\end{array}$

Shale with sandy shale $\quad 4 \quad 836$

Shale with sandy shale layers $\quad 50 \quad 886$

$\begin{array}{lll}\text { Rock } & 1 & 887\end{array}$

Shale $\quad 13 \quad 900$ 


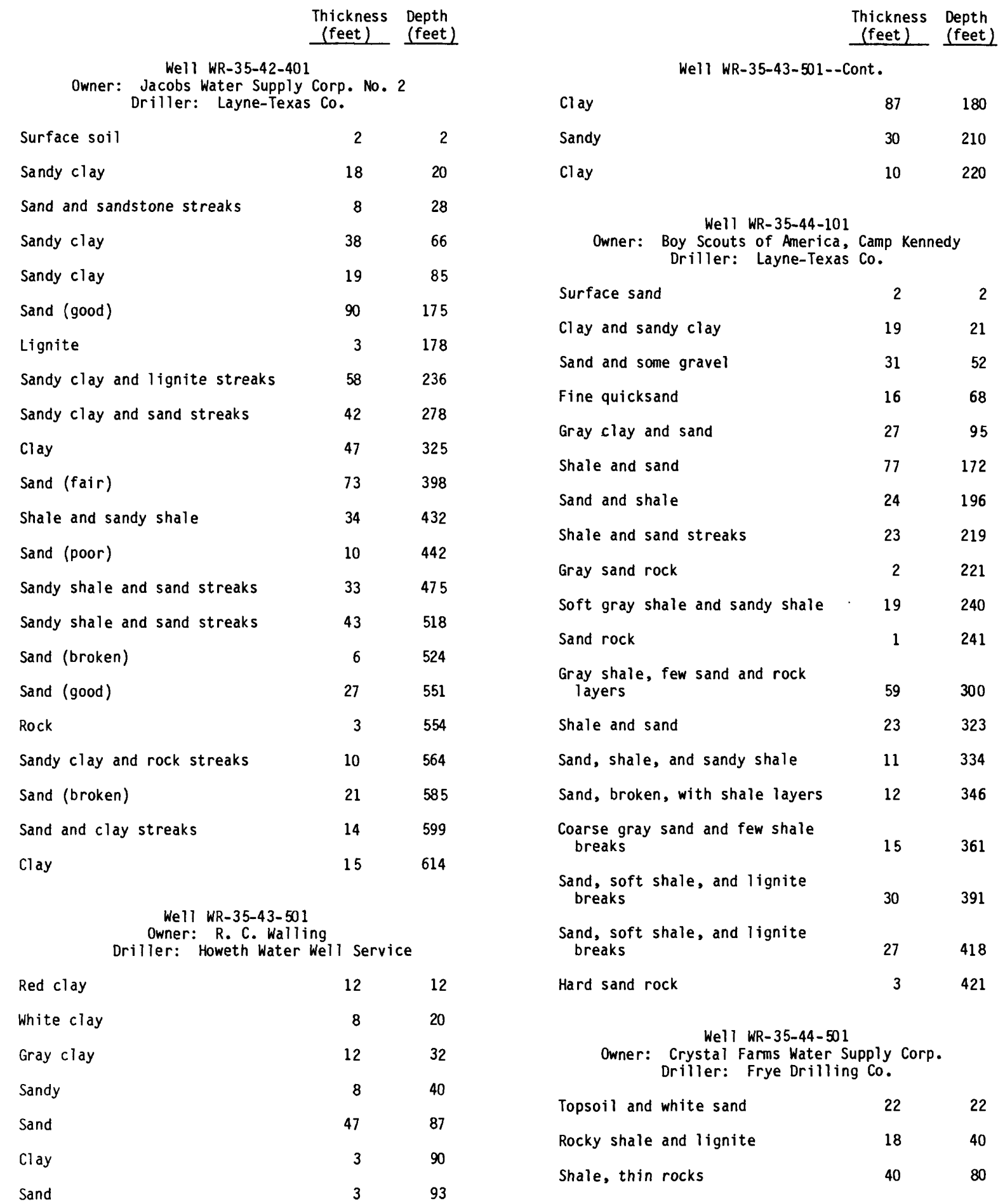


Table 2.--Drillers' logs of selected wells in Rusk County--Continued

Thickness Depth (feet) (feet)

Well WR-35-44-501--Cont.

\begin{tabular}{|c|c|c|}
\hline $\begin{array}{c}\text { Well WR-35-44-801 } \\
\text { Owner: Texas Utilities Service } \\
\text { Martin Lake Plant } \\
\text { Driller: Layne-Texas }\end{array}$ & $\begin{array}{l}\text { s, Inc., No } \\
\text { Co. }\end{array}$ & \\
\hline Iron rock and red sandy clay & 7 & 7 \\
\hline Gray sandy clay & 16 & 23 \\
\hline Lignite & 2 & 25 \\
\hline $\begin{array}{l}\text { Sandy shale, sand streaks, and } \\
\text { lignite streaks }\end{array}$ & 41 & 66 \\
\hline Lignite & 7 & 73 \\
\hline Sand with lignite and shale & 2 & 75 \\
\hline Sandy shale & 3 & 78 \\
\hline Sand, lignite streaks, and shale & 11 & 89 \\
\hline $\begin{array}{l}\text { Shale, sandy shale, and lignite } \\
\text { streaks }\end{array}$ & 34 & 123 \\
\hline Shale with sand streaks & 29 & 152 \\
\hline Sand and shale layers & 25 & 177 \\
\hline Rock & 1 & 178 \\
\hline Sand (cut good) & 16 & 194 \\
\hline Rock & 1 & 195 \\
\hline Sand (cut good) & 35 & 230 \\
\hline
\end{tabular}

$\begin{array}{lll}\text { Gray shale } & 21 & 101 \\ \text { Blue shale } & 20 & 121 \\ \text { Blue shale, lignite } & 41 & 162 \\ \text { shale and sand } & 21 & 183 \\ \text { Sand, shale, and rock } & 25 & 208 \\ \text { Shale and sand } & 16 & 224 \\ \text { Sand and shale } & 82 & 306 \\ \text { Rock sand and shale } & 20 & 326 \\ \text { Shale and rock } & 21 & 347 \\ \text { Sand } & 20 & 367 \\ \text { Rock and good sand } & 21 & 388 \\ \text { Shale and good sand } & 20 & 408 \\ \text { Good sand and rock } & 10 & 418\end{array}$

Well WR-35-44-801

Martin Lake Plant

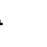

1

(1)

8

6

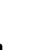

8

8

\section{Thickness Depth (feet) (feet)}


Table 2.--Drillers' logs of selected wells in Rusk County--Continued

Thickness Depth

(feet) (feet)

Well WR-35-49-206--Cont. Sand, sandy shale streaks, and
shale layers

Sand (cut good, coarse)

Shale, lignite, and sandy shale

Fine sand and sandy shale

Sand shale, lignite

Rock (hard)

Sandy shale and sand (broken)

Sandy shale and shale streaks (cut good)

Sandy shale and lignite, mixed

Sand and sandy shale (cut good)

Sandy shale and sand streaks

Sand and sandy shale streaks

Shale and sandy shale (cut hard)

Sand

Rock (hard)

Sand and shale streaks

Sandy shale

Sand

Sandy shale and sand streaks

Sand and shale streaks

Sandy shale

Sand and sandy shale

Sandy shale and lignite streaks

Sand

Sandy shale and lignite streaks

Sand and sandy shale (broken

layers)

Sandy shale and lignite streaks

Sand and sandy shale and lignite

Sand

Sandy shale, lignite, and sand streaks

\begin{tabular}{|c|c|}
\hline 48 & 161 \\
\hline 77 & 238 \\
\hline $52^{\circ}$ & 290 \\
\hline 11 & 301 \\
\hline 28 & 329 \\
\hline 4 & 333 \\
\hline 25 & 358 \\
\hline 25 & 383 \\
\hline 61 & 444 \\
\hline 37 & 481 \\
\hline 42 & 523 \\
\hline 16 & 539 \\
\hline 86 & 625 \\
\hline 5 & 630 \\
\hline 2 & 632 \\
\hline 19 & 651 \\
\hline 6 & 657 \\
\hline 8 & 665 \\
\hline 9 & 674 \\
\hline 27 & 701 \\
\hline 9 & 710 \\
\hline 19 & 729 \\
\hline 8 & 737 \\
\hline 4 & 741 \\
\hline 29 & 770 \\
\hline 32 & 802 \\
\hline 15 & 817 \\
\hline 6 & 823 \\
\hline 8 & 831 \\
\hline 9 & 840 \\
\hline
\end{tabular}

Thickness Depth

(feet) (feet)

Well WR-35-49-206--Cont.

$\begin{array}{lcc}\begin{array}{l}\text { Sand, sandy shale, and lignite } \\ \text { (broken) }\end{array} & 21 & 801 \\ \begin{array}{l}\text { Sand and lignite streaks (cut } \\ \text { good) }\end{array} & 27 & 888 \\ \begin{array}{l}\text { Sandy shale, sand, and lignite } \\ \text { streaks }\end{array} & 29 & 917 \\ \text { Sand } & 14 & 931 \\ \text { Shale and sandy shale } & 14 & 945 \\ \text { Sand and shale streaks } & 11 & 956 \\ \text { Sandy shale and lignite streaks } & 7 & 963 \\ \text { Rock } & 1 & 964 \\ \text { Sandy shale, shale, and lignite } \\ \text { streaks }\end{array}$

Well WR-35-49-601

Owner: Gaston Water Supply Corp. No. 1 Drilling: Edington Drilling Co.

$\begin{array}{lcc}\text { Clay } & 22 & 22 \\ \text { Shale } & 41 & 63 \\ \text { Sand } & 20 & 83 \\ \text { Shale } & 21 & 104 \\ \text { Sand } & 28 & 132 \\ \text { Shale } & 34 & 166 \\ \text { Sand, 185 - rock } & 20 & 186 \\ \text { Shale rock } & 21 & 207 \\ \text { Shale } & 102 & 309 \\ \text { Sand shale } & 21 & 330 \\ \text { Shale } & 21 & 351 \\ \text { Sand } & 15 & 366 \\ \text { Shale } & 66 & 432 \\ \text { Sand } & 20 & 452\end{array}$


Table 2.--Drillers' logs of selected wells in Rusk County--Continued

\section{Thickness Depth (feet) (feet)}

Well WR-35-49-601--Cont.

$\begin{array}{lrr}\text { Sand shale } & 21 & 473 \\ \text { Shale } & 9 & 482 \\ \text { Rock } & 18 & 500 \\ \text { Sand } & 18 & 518 \\ \text { Shale } & 16 & 534 \\ \text { Shale rock } & 21 & 555 \\ \text { Shale } & 61 & 616 \\ \text { Shale rock } & 21 & 637 \\ \text { Shale } & 21 & \underline{1} / 658\end{array}$

Well WR-35-50-206

Owner: Burris Dorsey

Driller: White Drilling Co.

Red, white, and yellow clay

Tan shale

$7 \quad 7$

White sand, some shale streaks

$20 \quad 27$

Lignite

Gray sticky shale

Sandy shale

Gray sticky shale

Gray brittle shale

Gray sticky shale

Gray sandy shale with heavy

$$
\text { lignite }
$$

Gray sticky shale

Brown shale and lignite

Gray sand

Brown and gray shale with some

lignite

Sandy shaie

Brown sticky shale

Gray sticky shale

Shale with thin lignite streak

Sandy shaie

Gray sand

1/ Well is deeper, but driller omitted bottom portion of log.

\begin{tabular}{|c|c|c|}
\hline & $\begin{array}{l}\text { Thickness } \\
\text { (feet) }\end{array}$ & \multirow[t]{2}{*}{$\begin{array}{l}\text { Depth } \\
\text { (feet) }\end{array}$} \\
\hline \multicolumn{2}{|c|}{$\begin{array}{l}\text { Well WR-35-50-502 } \\
\text { Owner: City of Henderson No. } 16 \\
\text { (formerly White Oak Water Co.) } \\
\text { Driller: Layne-Texas Co. }\end{array}$} & \\
\hline Surface soil and sand & 10 & 10 \\
\hline Gray clay & 18 & 28 \\
\hline Gray sand and lignite & 9 & 37 \\
\hline Gray shale and lignite streaks & 19 & 56 \\
\hline Gray sand and lignite streaks & 14 & 70 \\
\hline Shale, sand, and limestone streaks & 18 & 88 \\
\hline Sandy shale & 6 & 94 \\
\hline Sand and shale & 3 & 97 \\
\hline Shale, sand streaks, and lignite & 25 & 122 \\
\hline Sand and share & 12 & 134 \\
\hline Shale and lignite & 30 & 164 \\
\hline Sand and shale layers & 14 & 178 \\
\hline Sand, thin shale layers & 11 & 189 \\
\hline Sand and shale & 9 & 198 \\
\hline Shale & 15 & 213 \\
\hline Sand and shale streaks & 30 & 243 \\
\hline Sand and shale layers (cut good) & 12 & 255 \\
\hline Shale and sand layers & 18 & 273 \\
\hline Shale and sandy shale & 14 & 287 \\
\hline Sand and shale streaks (cut good) & 15 & 302 \\
\hline Sand (cut good) & 62 & 370 \\
\hline Sandy shale and shale layers & 6 & 370 \\
\hline Shale and sand streaks & 22 & 392 \\
\hline Sand and sandy shale & 10 & 402 \\
\hline Shale and sandy shale & 8 & 410 \\
\hline $\begin{array}{l}\text { Well WR-35-50-601 } \\
\text { Owner: Texas Highway R. } \\
\text { Driller: Works Progress Admi }\end{array}$ & $\begin{array}{l}.0 . \text { W. } \\
\text { ninistratio }\end{array}$ & \\
\hline Surface soil & 3.5 & 3.5 \\
\hline Sand rock & .5 & 4 \\
\hline Yellow and red clay & 2 & 6 \\
\hline Yellow clay & 1 & 7 \\
\hline
\end{tabular}

Owner: City of Henderson No. 16

formerly white Oak Water $\mathrm{Co}_{\text {.) }}$

Driller: Layne-Texas Co. 
Table 2.--Drillers' logs of selected wells in Rusk County--Continued

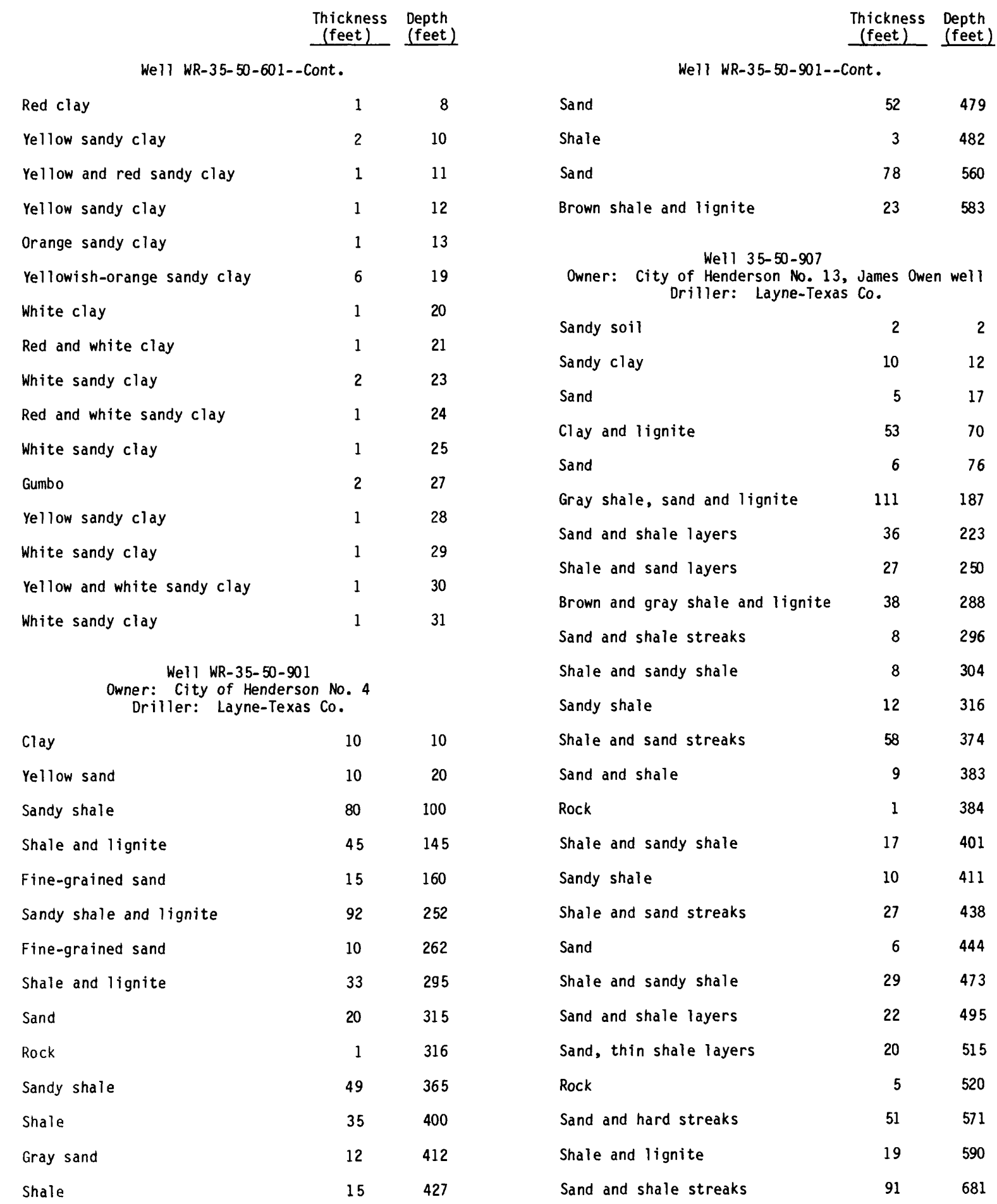


Table 2.--Drillers' logs of selected wells in Rusk County--Continued

Thickness Depth
(feet)

Well WR-35-50-907--Cont.

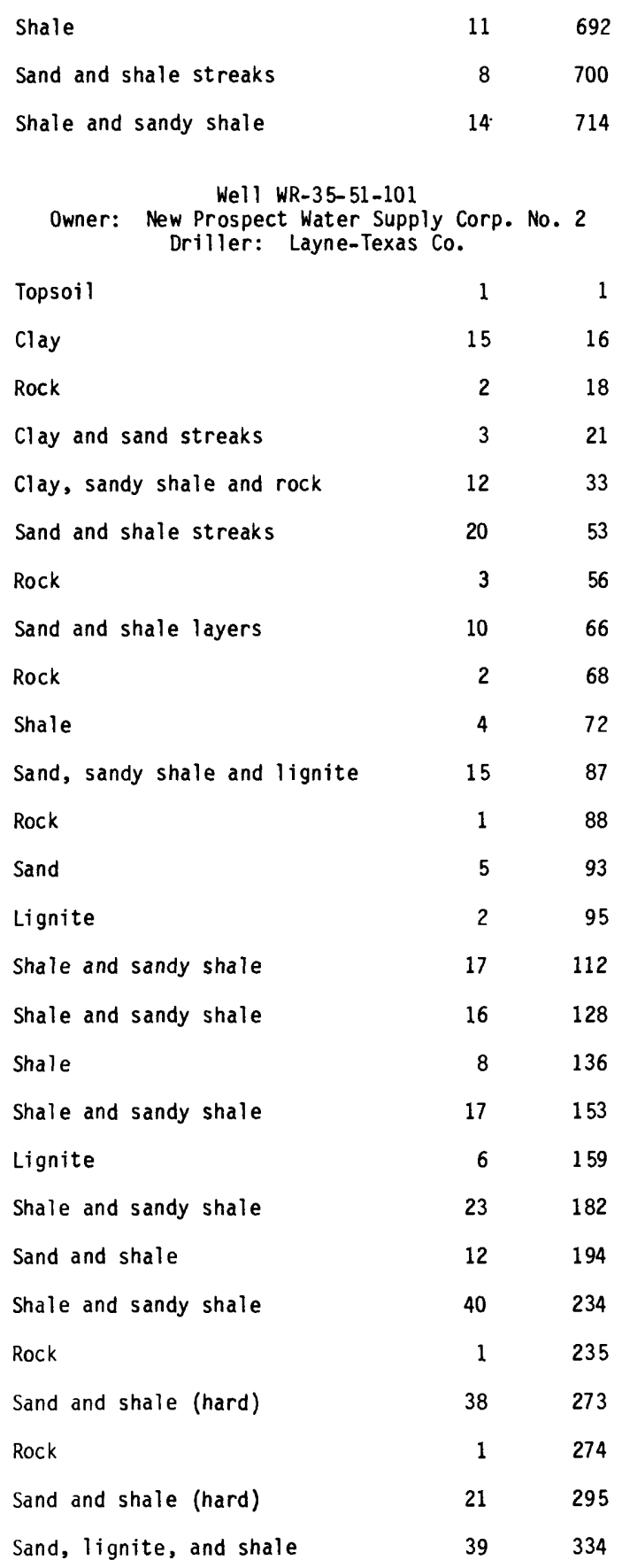

Thickness Depth (feet) (feet)

Well WR-35-51-101--Cont.

$\begin{array}{lrr}\text { Shale } & 30 & 364 \\ \text { Sand (fine) } & 12 & 376 \\ \text { Sandy shale and sand layers } & 4 & 380 \\ \text { Sand, shale, and lignite } & 61 & 441 \\ \text { Rock } & 1 & 442 \\ \text { Sand, shale, and lignite streaks } & 50 & 492 \\ \text { Shale } & 2 & 494 \\ \text { Sand and shale streaks (coarse) } & 22 & 516 \\ \text { Sandy shale and sand layers } & 18 & 534 \\ \text { Sand and shale layers } & 10 & 544 \\ \text { Shale, sandy shale, and sand } & & \\ \text { streaks } & 29 & 573 \\ \text { Sand, shale, and lignite streaks } & 11 & 584 \\ \text { Shale and rock layers (hard) } & 34 & 618 \\ \text { Sand (fine) } & 7 & 625 \\ \text { Lignite } & 3 & 628 \\ \text { Shale and lignite } & 6 & 634\end{array}$

Well WR-35-51-502

Owner: Church Hill Water Supply Corp. No. 2 Driller: Howeth Water Well Service

$\begin{array}{lcr}\text { Red and white clay } & 20 & 20 \\ \text { Sand } & 20 & 40 \\ \mathrm{Cl} \text { ay } & 76 & 116 \\ \text { Sand } & 24 & 140 \\ \mathrm{Cl} \text { ay } & 40 & 180 \\ \text { Sand } & 12 & 192 \\ \mathrm{Cl} \text { ay } & 208 & 400 \\ \text { Sand } & 40 & 440 \\ \text { Coal, clay, and sand } & 24 & 464 \\ \text { Sand, streaked } & 44 & 508 \\ \text { Cl ay } & 42 & 550 \\ \text { Sandy } & 30 & 580 \\ \text { Cl ay } & 30 & 610\end{array}$


Table 2.--Drillers' logs of selected wells in Rusk County--Continued

\begin{tabular}{c}
$\begin{array}{c}\text { Thickness } \\
\text { (feet) }\end{array}$ (feet) \\
\hline
\end{tabular}

Well WR-35-52-101

Owner: Evel Faulkner

Driller: Howeth Water Well Service

$\begin{array}{lcr}\text { White-yel low clay } & 21 & 21 \\ \text { Sand clay } & 3 & 24 \\ \text { Clay } & 4 & 28 \\ \text { Sand clay } & 7 & 35 \\ \text { Dark clay } & 13 & 48 \\ \text { Coal } & 7 & 55 \\ \text { Cl ay } & 7 & 62 \\ \text { Sand } & 6 & 68 \\ \text { Cl ay } & 33 & 101 \\ \text { Coal } & 2 & 103 \\ \text { Cl ay } & 7 & 110 \\ \text { Sand } & 71 & 188 \\ \text { Cl ay } & 713 \\ \text { Sand } & 3 & 192 \\ \text { Clay } & 61 & 174\end{array}$

Well WR-35-52-701

Owner: H. H. Truelock Driller: Howeth Water Well Service

$\begin{array}{lcc}\text { Clay } & 30 & 30 \\ \text { Sand, streaked } & 15 & 45 \\ \text { Clay } & 30 & 75 \\ \text { Coal } & 9 & 84 \\ \text { Clay } & 16 & 100 \\ \text { Sand, streaked } & 15 & 115 \\ \text { Clay } & 155 & 270 \\ \text { Sand } & 26 & 296 \\ \text { Clay } & 6 & 302\end{array}$

Well WR-35-57-203

Owner: Amoco Production Co. No. 3, Siler Lease Driller: Layne-Texas Co.

Topsoil

Sand
Thickness Depth

(feet) (feet)

Wel 1-WR-35-57-203--Cont.

\begin{tabular}{|c|c|c|}
\hline Sandy shale and lignite & 38 & 62 \\
\hline Sand & 5 & 67 \\
\hline Sand and gravel & 35 & 102 \\
\hline Sand and shale streaks & 18 & 120 \\
\hline Sand & 5 & 125 \\
\hline Sandy shale and sand layers & 35 & 160 \\
\hline Sand & 13 & 173 \\
\hline Shale & 11 & 184 \\
\hline Sand and lignite & 10 & 194 \\
\hline Sandy shale & 74 & 268 \\
\hline Sand, lignite, and shale streaks & 33 & 301 \\
\hline Shale and sandy shale & 25 & 326 \\
\hline Sand and shale streaks & 39 & 365 \\
\hline Rock & 1 & 366 \\
\hline Sandy shale & 19 & 385 \\
\hline Sand & 6 & 391 \\
\hline Shale & 13 & 404 \\
\hline Shale and sandy shale & 26 & 430 \\
\hline Sand and shale streaks & 23 & 453 \\
\hline Shale and sand streaks & 18 & 471 \\
\hline Sand & 8 & 479 \\
\hline Shale and sandy shale & 25 & 504 \\
\hline Sand & 8 & 512 \\
\hline Rock & 1 & 513 \\
\hline Sand with shale streaks & 5 & 518 \\
\hline Sandy shale & 17 & 535 \\
\hline Sand and shale layers & 15 & 550 \\
\hline Rock & 1 & 551 \\
\hline Sand & 34 & 584 \\
\hline Rock & 2 & 586 \\
\hline Shale & 2 & 588 \\
\hline Rock & 2 & 590 \\
\hline
\end{tabular}


Table 2.--Drillers' logs of selected wells in Rusk County--Continued

\section{Thickness Depth}

(feet) (feet)

Well WR-35-57-203--Cont.

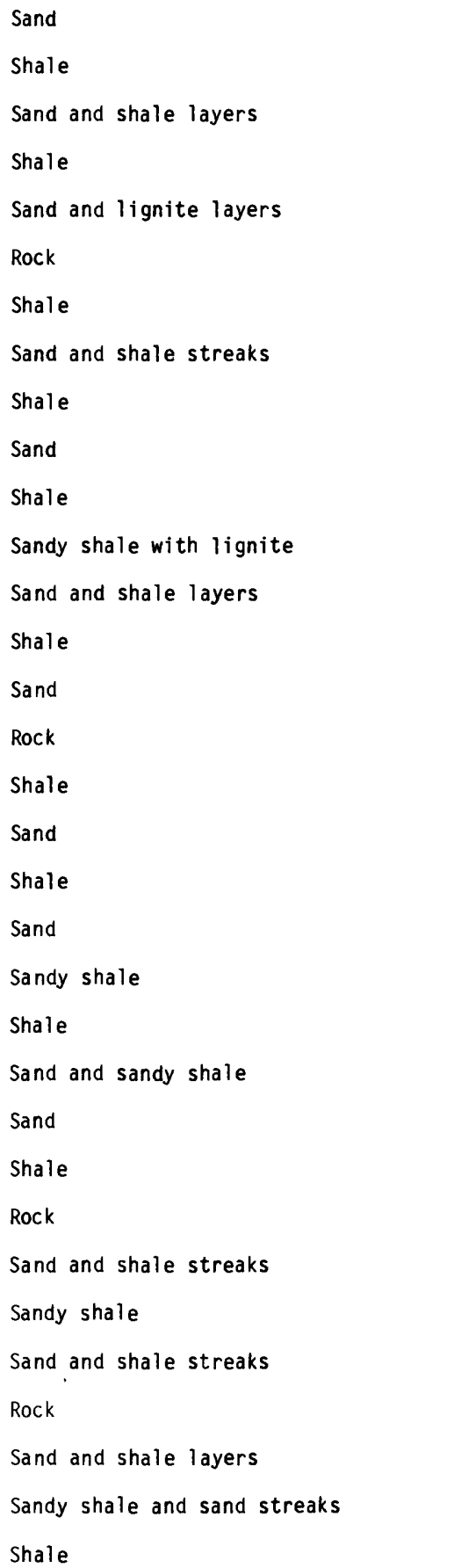

$16 \quad 606$

$7 \quad 613$

$39 \quad 652$

$3 \quad 655$

$23 \quad 678$

$1 \quad 679$

$5 \quad 684$

$15 \quad 699$

$12 \quad 711$

$38 \quad 749$

$11 \quad 760$

$60 \quad 820$

$60 \quad 880$

$19 \quad 899$

6905

1906

2908

2910

$9 \quad 919$

$19 \quad 938$

11949

14963

22985

$23 \quad 1,008$

51,013

21,015

251,040

121,052

$15 \quad 1,067$

31,070

$34 \quad 1,104$

$21 \quad 1,125$

$10 \quad 1,135$
Thickness Depth

(feet) (feet)

Well WR-35-57-901

Owner: W. A. Whitehead Driller: White Drilling Co.

Brown, tan, and yellow clay with

$\begin{array}{rr}20 & 20 \\ 35 & 55 \\ 45 & 100 \\ 50 & 150 \\ 15 & 165 \\ 5 & 170 \\ 40 & 210 \\ 20 & 230 \\ 40 & 270 \\ 45 & 315\end{array}$

Gray sand

Well WR-35-58-102

Owner: Goodsprings Water Supply Corp. Driller: Edington Drilling Co.

$\begin{array}{lrr}\text { Clay } & 22 & 22 \\ \text { Sand } & 48 & 70 \\ \text { Shale } & 70 & 140 \\ \text { Sandy shale } & 41 & 186 \\ \text { Shale } & 9 & 195 \\ \text { Sand } & 11 & 206 \\ \text { Shale } & 61 & 267 \\ \text { Sand } & 8 & 275 \\ \text { Shale } & 54 & 329 \\ \text { Sand } & 20 & 349 \\ \text { Shale } & 41 & 390 \\ \text { Shale and rock layers } & 20 & 410 \\ \text { Shale } & 82 & 492 \\ \text { Sand } & 82 & 574 \\ \text { Shale } & 20 & 594 \\ \text { Shale } & 14 & 608 \\ \text { Sand } & 7 & 615 \\ \text { Shale and sandy shale } & 20 & 635 \\ \text { Shale } & 7 & 642\end{array}$


Table 2.--Drillers' logs of selected wells in Rusk County--Continued

$$
\begin{gathered}
\begin{array}{c}
\text { Thickness } \\
\text { (feet) }
\end{array} \text { (feet) } \\
\hline
\end{gathered}
$$

\begin{tabular}{|c|c|c|}
\hline Sand & 8 & 650 \\
\hline Shale & 6 & 656 \\
\hline $\begin{array}{l}\text { Well WR-35-59-803 } \\
\text { Owner: Mobil Dil Corp. No } \\
\text { Driller: Edington Drilling }\end{array}$ & g 3 & \\
\hline Surface clay and sand & 25 & 25 \\
\hline Gray shale & 108 & 133 \\
\hline Rock & 1 & 134 \\
\hline Gray shale & 13 & 147 \\
\hline Gray sand & 43 & 190 \\
\hline Gray shale & 161 & 351 \\
\hline Gray sand & 41 & 392 \\
\hline Gray shale & 263 & 655 \\
\hline Fine white sand & 65 & 720 \\
\hline Gray sandy shale & 44 & 764 \\
\hline Gray shale & 11 & 775 \\
\hline
\end{tabular}

Well WR-35-58-102--Cont .

Well WR-35-59-902

Owner: J. G. Spradlin Driller: Howeth Water Well Service

$\begin{array}{lcc}\text { Red and yellow clay } & 20 & 20 \\ \text { Clay } & 20 & 40 \\ \text { Sandy } & 19 & 59 \\ \text { Clay } & 47 & 106 \\ \text { Sand } & 14 & 120 \\ \text { Cl ay } & 178 & 298 \\ \text { Sandy bed } & 77 & 375 \\ \text { Cl ay } & 73 & 448 \\ \text { Sand streaks } & 32 & 480\end{array}$

Well WR-37-01-501

Owner: New Salem Water Supply Corp. Driller: Triangle Pump \& Supply Co.

Clay and sand

5

clay and rock, red

25

Sand, fine, white
650

56 25 47
20

775


Table 2.--Drillers' logs of selected wells in Rusk County--Continued

\section{Thickness Depth \\ (feet) (feet)}

Well WR-37-02-701--Cont.

$\begin{array}{lrr}\text { Hardpacked sand } & 12 & 610 \\ \text { Sand, shale, hardpacked } & 74 & 684 \\ \text { Sand } & 70 & 754 \\ \text { Shale } & 86 & 840 \\ \text { Hardpacked sand } & 30 & 870 \\ \text { Streaky sand and shale } & 90 & 960 \\ \text { Good sand } & 110 & 1,070 \\ \text { Shale } & 5 & 1,075\end{array}$

Well WR-37-03-202

Owner: Mount Enterprise Water Supply Corp. No. 3 Driller: Key Drilling Co.

$\begin{array}{lcc}\text { Sand } & 126 & 126 \\ \text { Shale } & 18 & 144 \\ \text { Sand } & 10 & 154 \\ \text { Sandy shale } & 48 & 202 \\ \text { Sand } & 36 & 238 \\ \text { Shale } & 72 & 310 \\ \text { Sand } & 50 & 360 \\ \text { Sandy shale } & 54 & 414 \\ \text { Sand } & 60 & 474 \\ \text { Sandy shale } & 10 & 484\end{array}$

Well WR-37-04-401

Owner: Arlam-Concord Water Supply Corp. "A"

Driller: Triangle Pump \& Supply Co.

$\begin{array}{lcc}\text { Sand and clay } & 20 & 20 \\ \text { Sandy shale, clay } & 26 & 46 \\ \text { Rock, red } & 3 & 49 \\ \text { Rock } & 54 & 103 \\ \text { Lignite } & 25 & 128 \\ \text { Sand } & 32 & 160 \\ \text { Shale } & 38 & 198 \\ \text { Rock } & 1 & 199 \\ \text { Shale and sand streaks } & 101 & 300\end{array}$

Thickness Depth

(feet) (feet)

Well WR-37-04-401--Cont.

Sand, fine, white, gray
Shale
Sand
Shale
Sand, fine, white
Shale, black and dark blue
Well WR-37-04-601
Owner: Fred Anderson

Driller: Allen Lumber Co.

\begin{tabular}{lcr} 
Red clay & 3 & 3 \\
Gray clay & 4 & 7 \\
Brown shale & 13 & 20 \\
Gray shale & 37 & 57 \\
Dark sand & 3 & 60 \\
Shale & 3 & 63 \\
Dark sand & 7 & 70 \\
Shale & 13 & 83 \\
White sand & 17 & 100 \\
Shale & 80 & 180 \\
Sand & 9 & 189 \\
Shale & 29 & 218 \\
Sand stringers & 44 & 262 \\
Sand & 23 & 285 \\
Sand stringers & 510 \\
Shale & & 315 \\
\hline
\end{tabular}

Well WR-37-11-103

Owner: Atlantic Pipeline Co. Driller: Layne-Texas Co.

$\begin{array}{lcc}\text { Sand } & 3 & 3 \\ \text { Clay } & 22 & 25 \\ \text { Blue shale } & 45 & 70 \\ \text { Rock } & 1 & 71 \\ \text { Shale } & 23 & 94\end{array}$


Table 2.--Drillers' logs of selected wells in Rusk County--Continued

$$
\begin{gathered}
\begin{array}{c}
\text { Thickness } \\
\text { (feet) }
\end{array} \text { (feet) } \\
\hline
\end{gathered}
$$

\begin{tabular}{|c|c|c|}
\hline Rock & 3 & 97 \\
\hline $\begin{array}{l}\text { Blue shale, hard streaks, sand } \\
\text { and lignite }\end{array}$ & 100 & 197 \\
\hline Hard shale & 73 & 270 \\
\hline Shale & 54 & 324 \\
\hline Rock & 1 & 325 \\
\hline Shale & 47 & 372 \\
\hline Sand & 23 & 395 \\
\hline $\begin{array}{l}\text { Well WR-37-12- } \\
\text { Owner: Arlam-Concord Wate } \\
\text { Driller: Triangle Pump }\end{array}$ & $\begin{array}{l}02 \\
\text { Supply Corp. } \\
\text { Supply Co. }\end{array}$ & \\
\hline $\mathrm{Clay}$ and sand & 7 & 7 \\
\hline Sand, white, fine & 63 & 70 \\
\hline Sandy shale & 40 & 110 \\
\hline Shale & 20 & 130 \\
\hline Sand, real fine, white & 90 & 220 \\
\hline Sand streaks and sandy shale & 50 & 270 \\
\hline Sand, coarse gray and white & 60 & 330 \\
\hline Shale & 40 & 370 \\
\hline Sand & 60 & 430 \\
\hline Sand and shale streaks & 178 & 608 \\
\hline
\end{tabular}

Well WR-37-11-103--Cont. 
Table 3.--Water levels in wells in Rusk and Cherokee Counties

(Water levels in feet below land surface;

total depth indicates depth to which well is drilled or depth to which casing is set, if known)

RUSK COUNTY

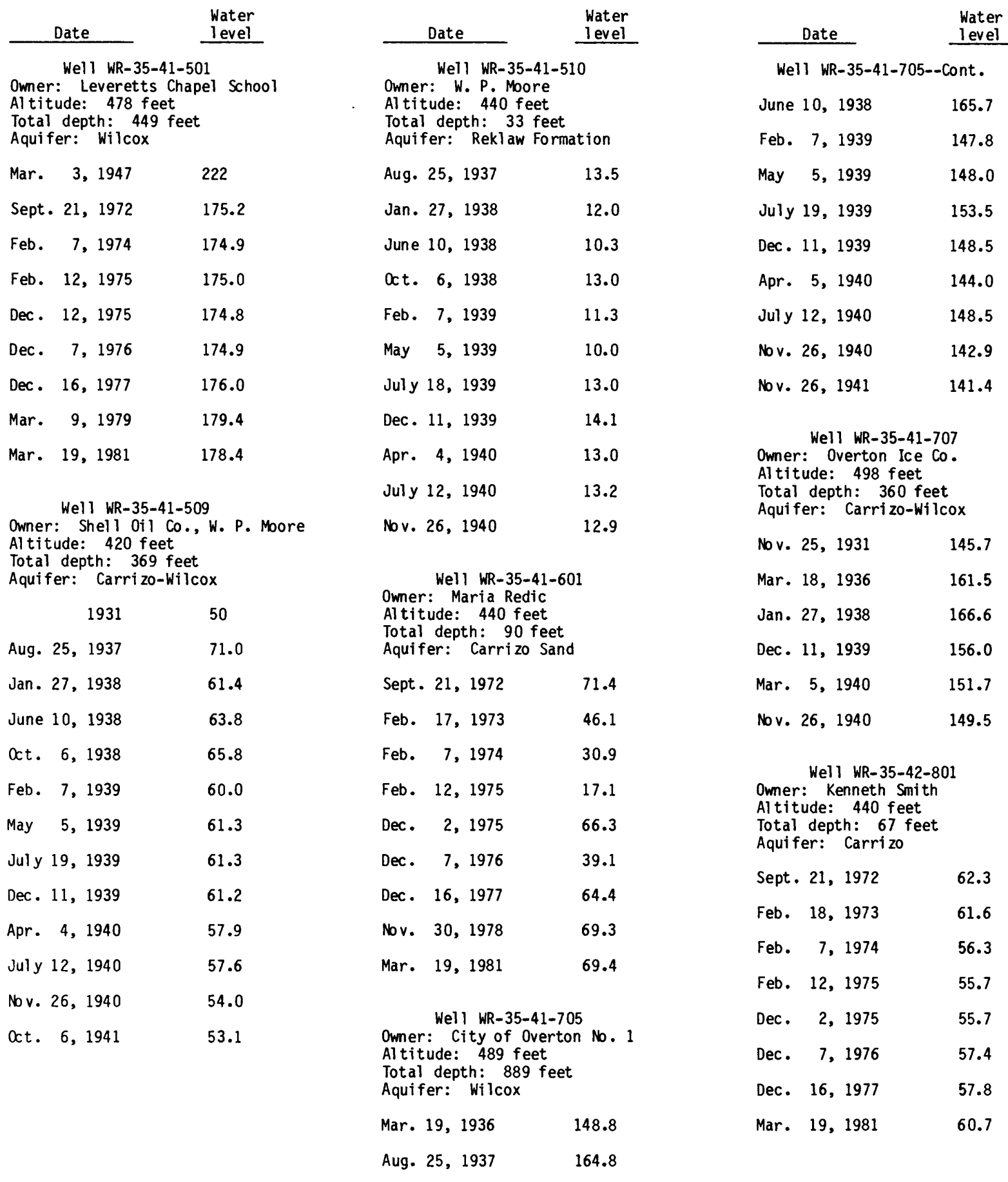


Table 3.--Water levels in wells in Rusk and Cherokee Counties--Continued

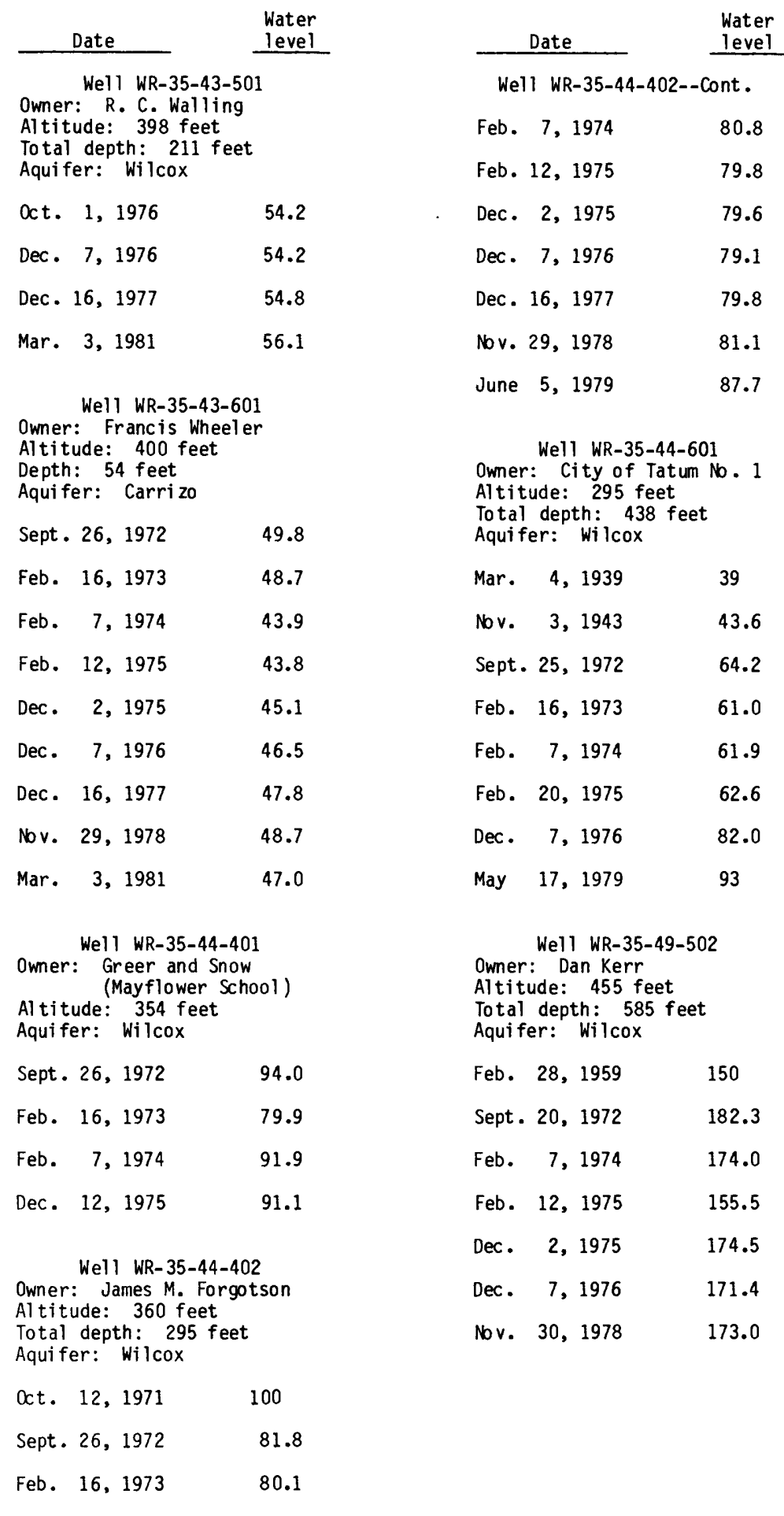

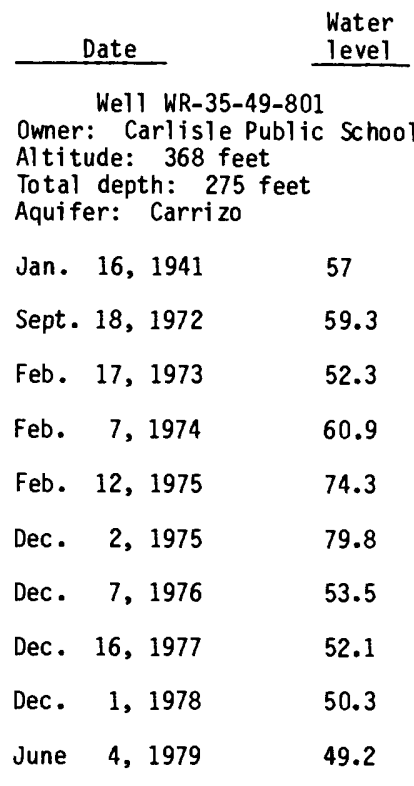

Well WR-35-50-302

Owner: Jerome Rhoden

Altitude: 402 feet

Total depth: 49 feet

Aquifer: Carrizo

Sept. 21, $1972 \quad 28.0$

Feb. $18,1973 \quad 11.0$

Feb. $7,1974 \quad 8.6$

Feb. $12,1975 \quad 9.8$

Dec. 2, $1975 \quad 18.2$

Dec. 7, $1976 \quad 15.4$

Dec. 16, $1977 \quad 18.4$

Dec. $1,1978 \quad 12.1$

Mar. 19, $1981 \quad 18.4$

Well WR-35-50-501

Owner: Joe Hartman

Altitude: 460 feet

Total depth: 48 feet

Aquifer: Carrizo Sand

Sept. 21, $1972 \quad 32.8$

Feb. 17, $1973 \quad 31.2$

Feb. $7,1974 \quad 25.4$

Feb. $12,1975 \quad 28.0$ 
Table 3.-- Water levels in wells in Rusk and Cherokee Counties--Continued

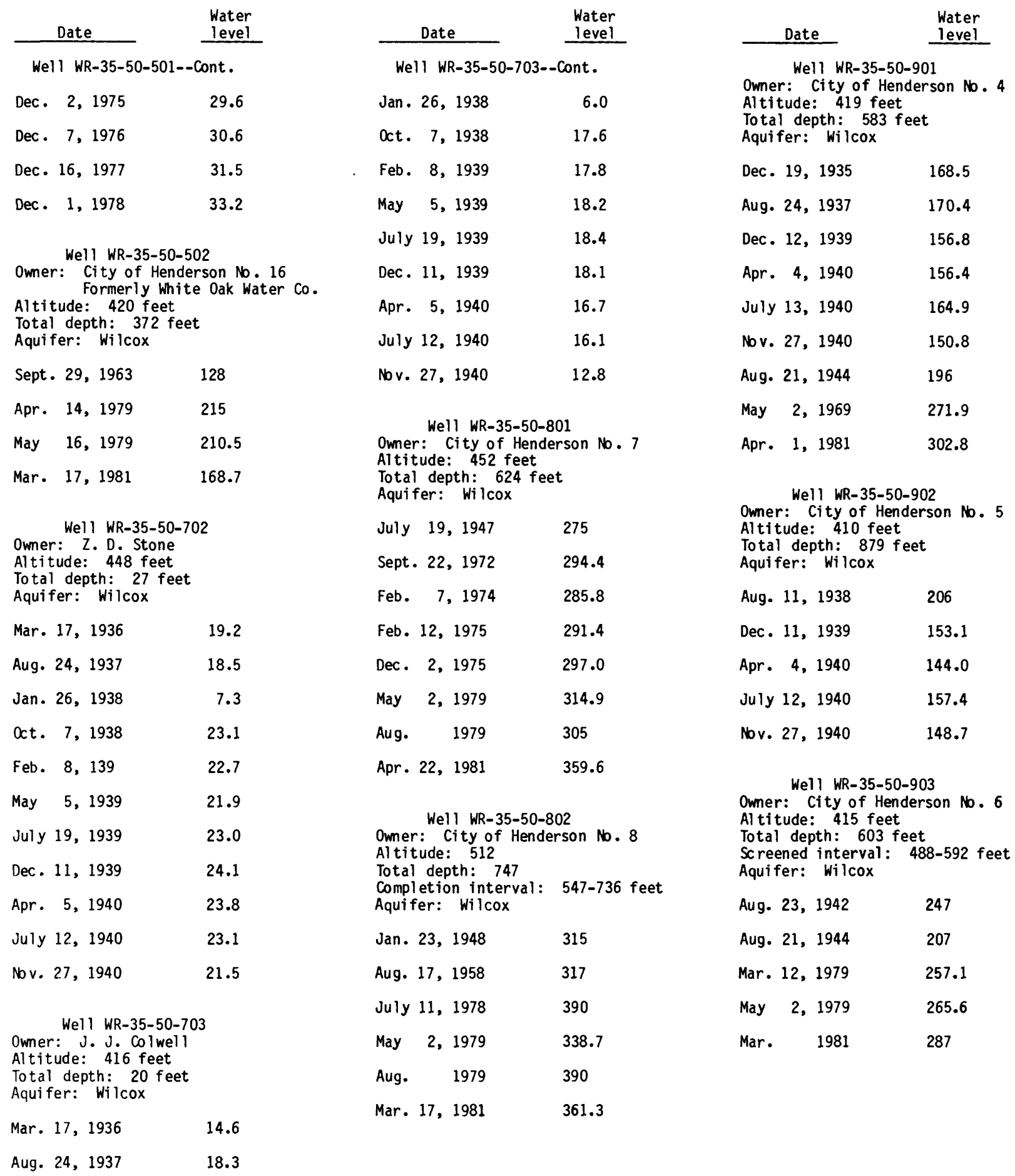


Table 3.--Water levels in wells in Rusk and Cherokee Counties--Continued

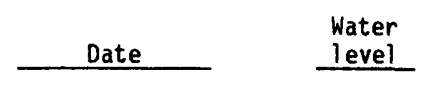

Well WR-35-50-904

Owner: City of Henderson No. 10

Altitude: 455 feet

Total depth: 698 feet

Screened interval: $510-686$ feet

Aquifer: Wilcox

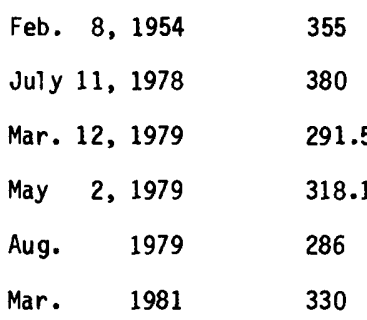

Well WR-35-50-907

Owner: City of Henderson No. 13, James Owen well

Altitude: 465 feet

Total depth: 712 feet

Aquifer: Wilcox

$\begin{array}{lrl}\text { Feb. } 1,1964 & 233 \\ \text { Mar. } & 13,1979 & 302.1 \\ \text { May } & 2,1979 & 291.2 \\ \text { Aug. } & 1979 & 302 \\ \text { Mar. } & 1981 & 319\end{array}$

Well WR-35-50-910

Owner: City of Henderson No. 2

Al titude: 404 feet

Total depth: 558 feet

Completion interval: $445-558$ feet

Aquifer: Wilcox

Oct. 7, $1938 \quad 178.0$

Feb. $8,1939 \quad 163.4$

Dec. $12,1939 \quad 167$

JuTy 13, 1940

Nbv. 27,1940

Well WR-35-50-912

Owner: 0. F. Burt

Altitude: 482 feet

Total depth: 51 feet

Aquifer: Carrizo

Aug. 24, 1937

6.0

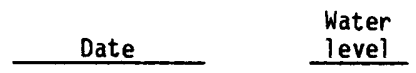

Well WR-35-50-912--Cont.

Jan. 27,1938

$1 /$

June 11,1938

2.2

Oct. 7, 1938

1/

Feb. 8,1939

1.8

Well WR-35-50-913

Owner: Rosa Burt

Altitude: 468 feet

Total depth: 14 feet

Aquifer: Carrizo

Jul y 15, 1936

2.5

Jan. 1, 1938

1.0

June 11, 1938

4.3

Oct. 7, 1938

10.1

Feb. 8, 1939

3.0

May 6,1939

4.0

Jul y 19, 1939

7.6

Dec. 12, 1939

11.4

Apr. 5, 1940

3.5

July 13, 1940

4.5

Nov. 27,1940

4.4

Well WR-35-51-502

Owner: Church Hill Water Supply Corp. No. 2

Al titude: 452 feet

Total depth: 490 feet

Aquifer: Wilcox

Oct. 7, 1971

150

Oct. 7, 1971

178.5

Dec. 7, 1976

196.5

Dec. 16, 1977

202.7

May 3, 1979

209.4

Mar. 19, 1981

207.7
Water

Well WR-35-51-802

Owner: L. K. Ballow

Altitude: 440 feet

Total depth: 22 feet

Aquifer: Wilcox

Dec. 2, 1936

19.6

Aug. 24, 1937

18.9

Jan. 23, 1938

$2 / 2.2$

June 11, 1938

9.6

Oct. 7, 1938

20.4

Feb. 8,1939

$2 / 1.8$

May 6, 1939

8.3

July 19, 1939

19.0

Dec. 12, 1939

22.2

Apr. 5, 1940

July 13, 1940

Nov. 27,1940

Well WR-35-51-902

Owner: J. Russell Smith

Altitude: 385 feet

Total depth: 26 feet

Aquifer: Wilcox

Dec. 2, 1936

23.3

Aug. 24, 1937

Jan. 23, 1938

$2 / 5.4$

June 11, 1938

20.2

Oct. 8, 1938

25.6

Feb. 8, 1939

2/6.2

May 6, 1939

24.0

July 19, 1939

Dec. 12, 1939

26

Apr. 4, 1940

25.9

July 13, 1940

24.6

Nb v. 12,1940

6.4

1/ Water seeping into well, actual water level unknown. $2 /$ Measured in rain.

$$
-102-
$$


Table 3.--Water levels in wells in Rusk and Cherokee Counties--Continued

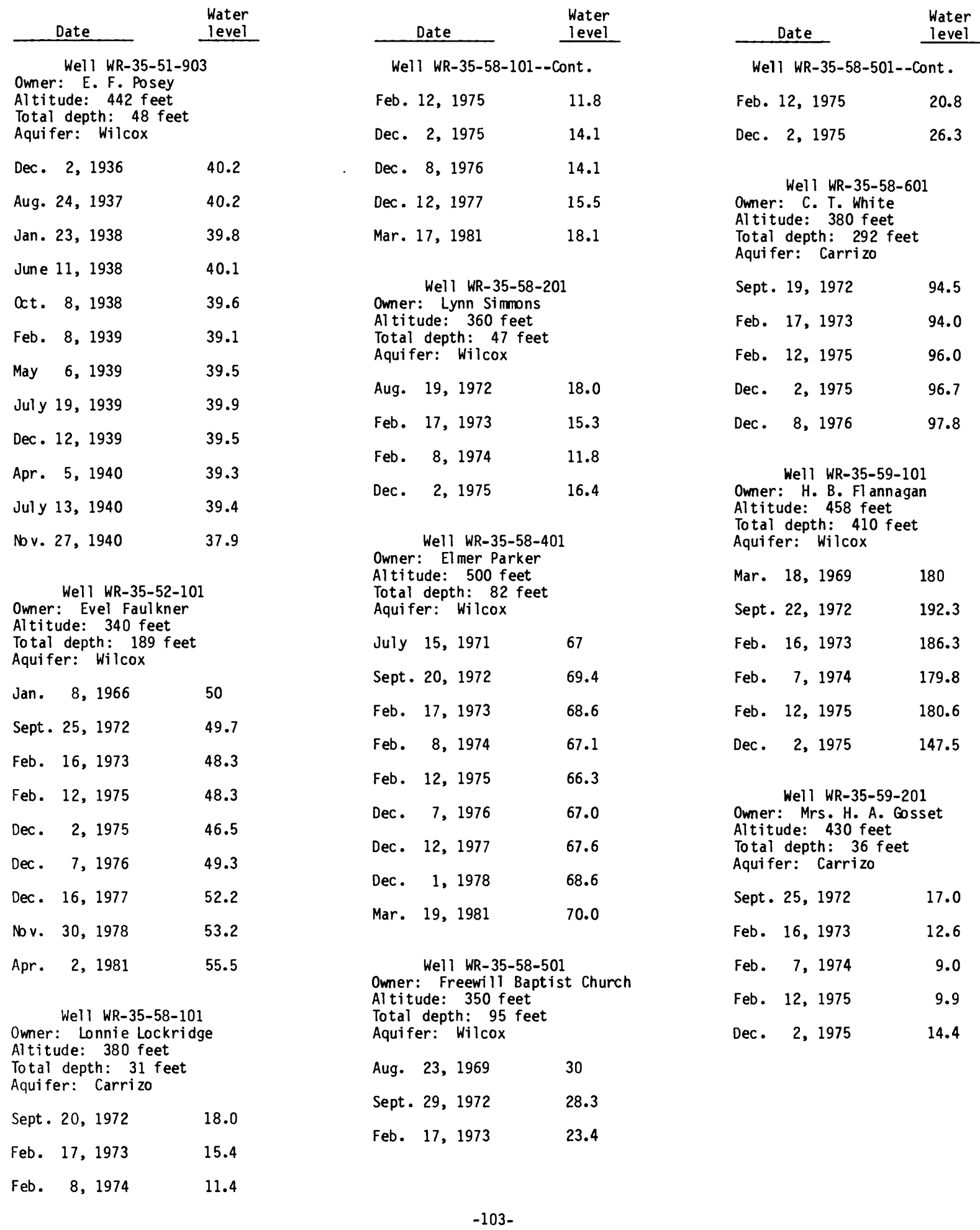


Table 3.--Water levels in wells in Rusk and Cherokee Counties--Continued

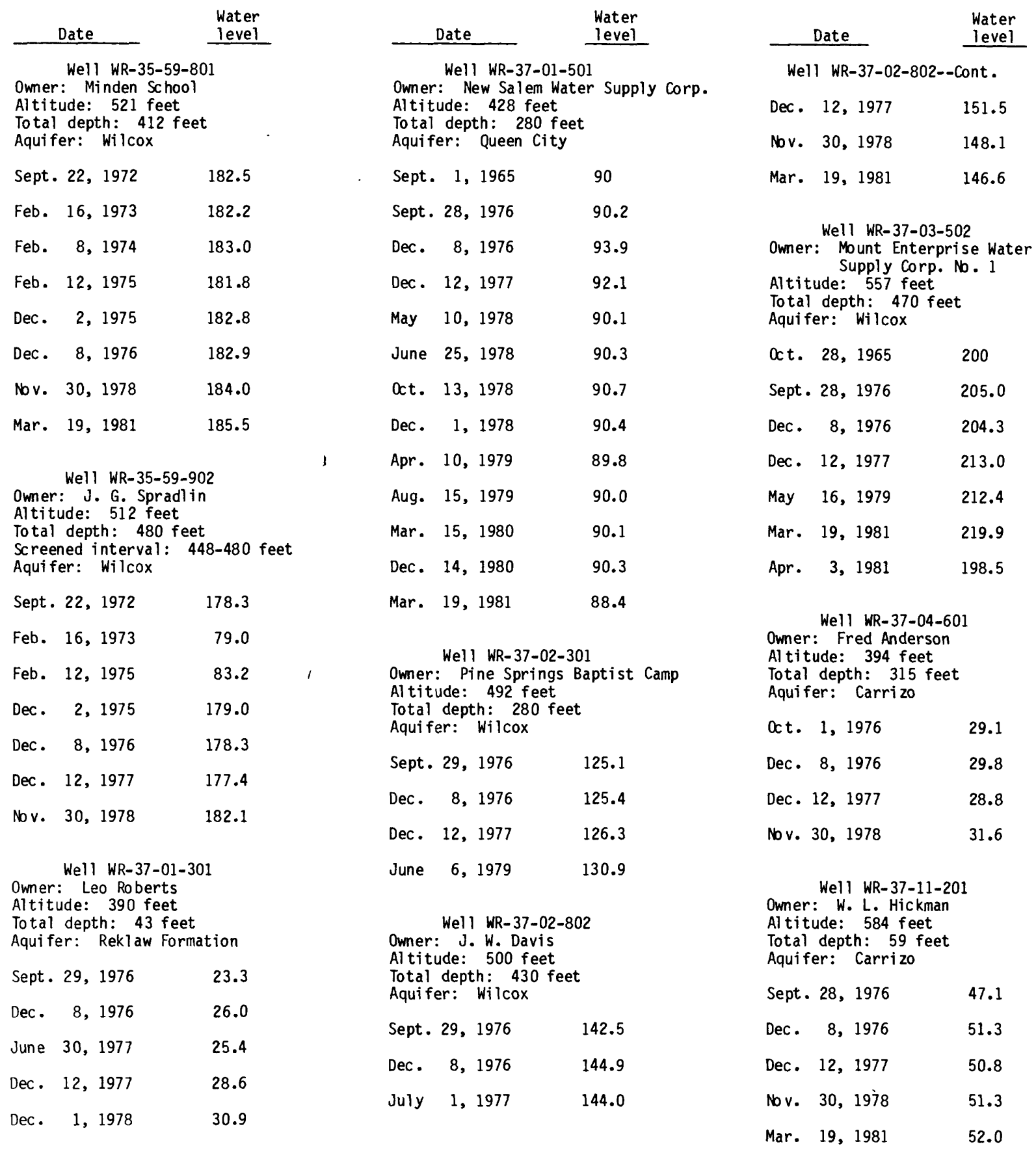


Table 3.--Water levels in wells in Rusk and Cherokee Counties--Continued

\section{CHEROKEE COUNTY}

Water
Date

Well WR-DJ-37-09-101

Owner: Reklaw Water Supply Corp. No. 2

Altitude: 300 feet

Total depth: 138 feet

Completion interval: 86-138 feet

Aquifer: Carrizo

Dec. 15, 1970

47.7

May 18,1971

46.9

Feb. 6, 1974

43.2

Feb. 19, 1975

45.7

Dec. 5, 1975

54.7

June 20, 1979

47

Apr. 2, 1981

Date $\quad \begin{aligned} & \text { Water } \\ & \text { level }\end{aligned}$

Wel I DJ-37-09-102

Owner: Reklaw Water Supply Corp. No. 1

Altitude: 300 feet

Total depth: 639 feet

Completion interval: 530-624 feet

Aquifer: Wilcox

May $\quad 1965 \quad 30$

Dec. $15,1970 \quad 23.6$

May 18, $1971 \quad 23.7$

Feb. $6,1974 \quad 26.0$

Feb. 19, $1975 \quad 26.9$

Dec. 5, $1975 \quad 28.0$

$\begin{array}{ll}\text { Dec. } 9,1976 & 28.8\end{array}$

Dec. 16, $1977 \quad 29.7$

Dec. 1, $1978 \quad 30.6$

$\begin{array}{ll}\text { Apr. } & 2,1981 \quad 31.8\end{array}$ 


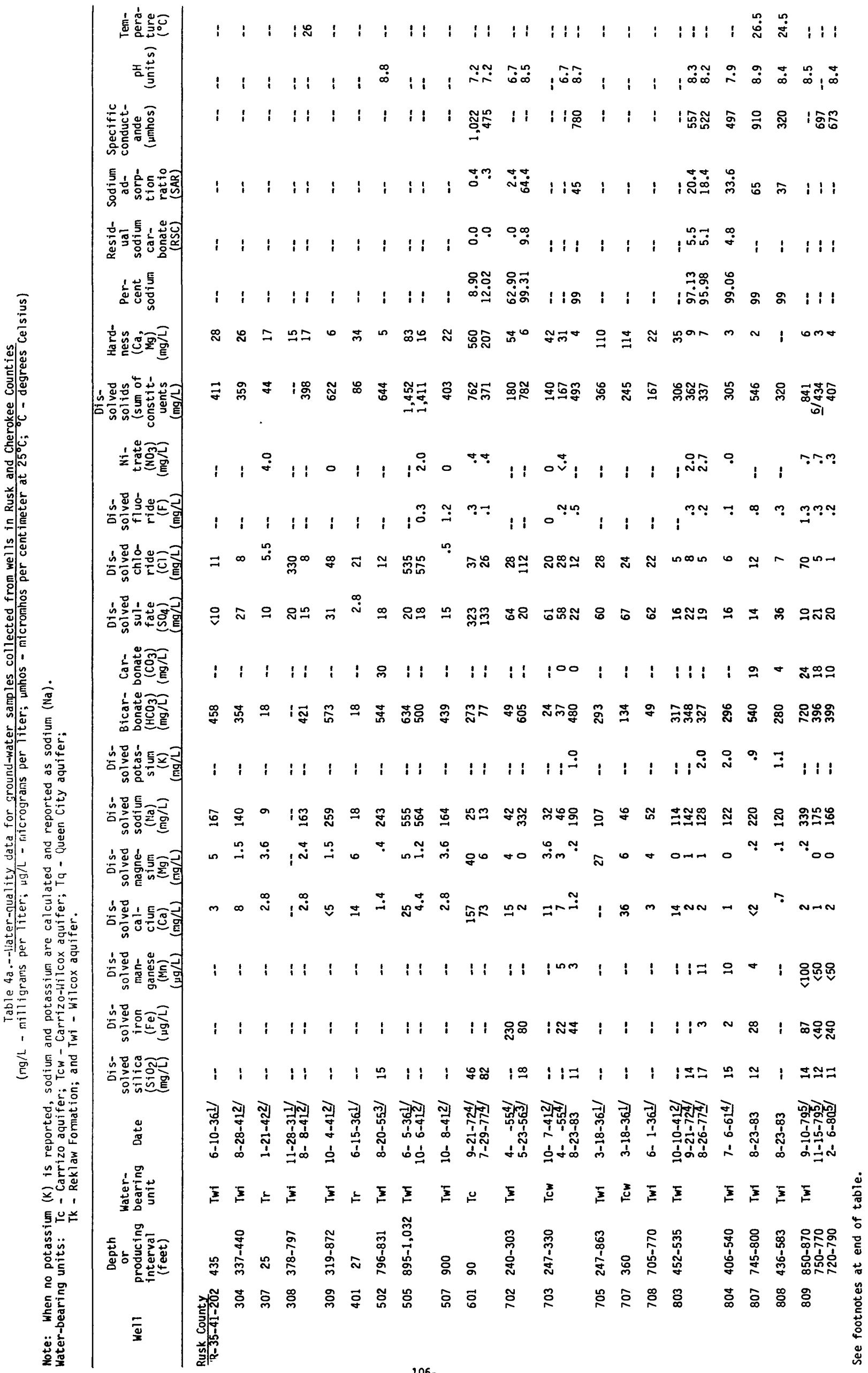




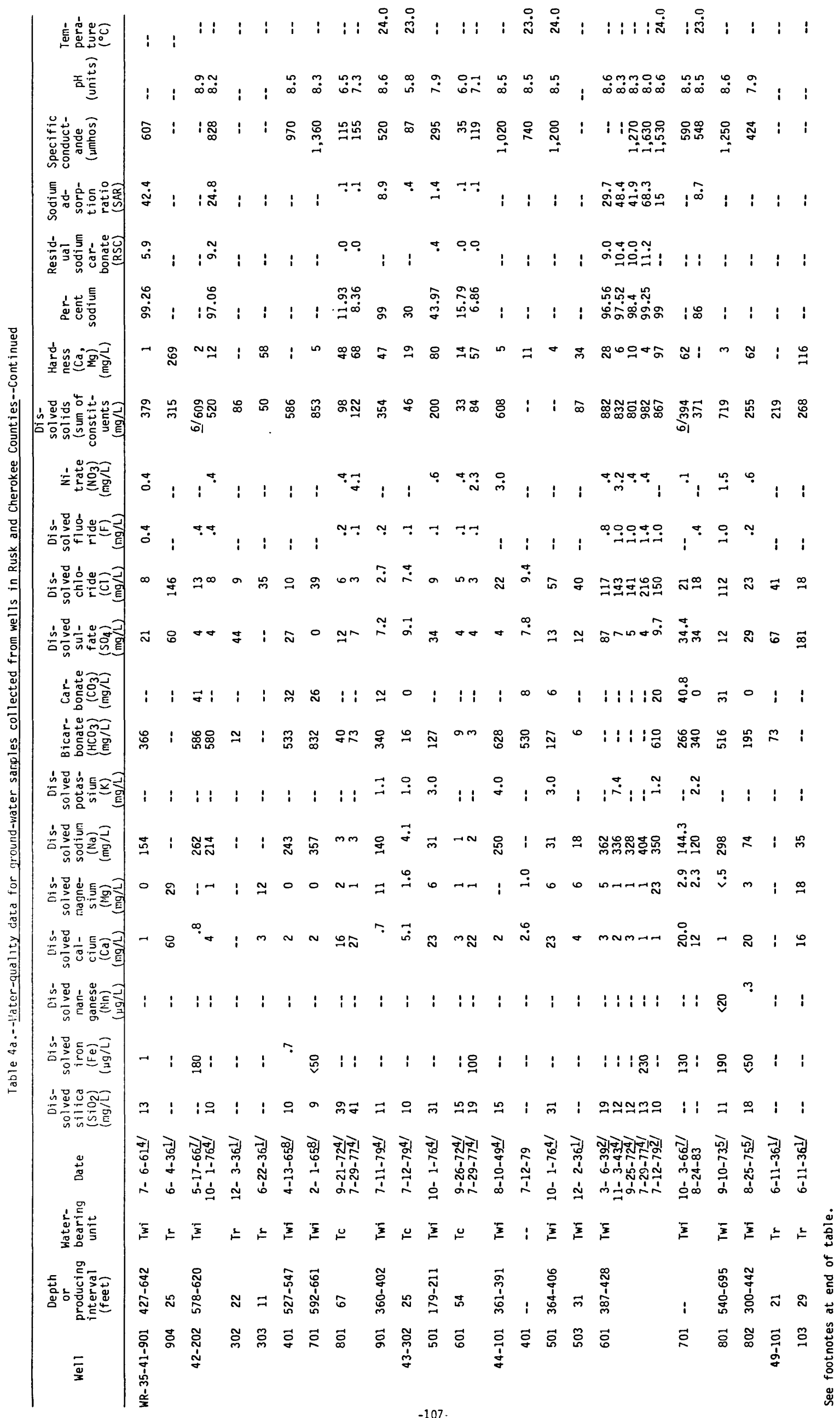




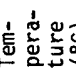

: : :

甛莺

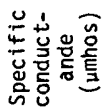

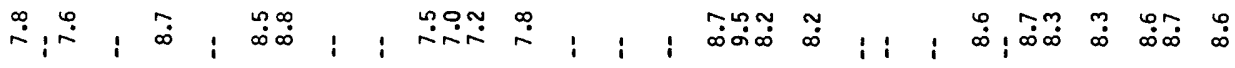

i 1 i i 尊

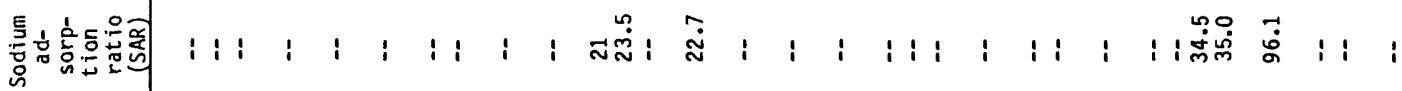

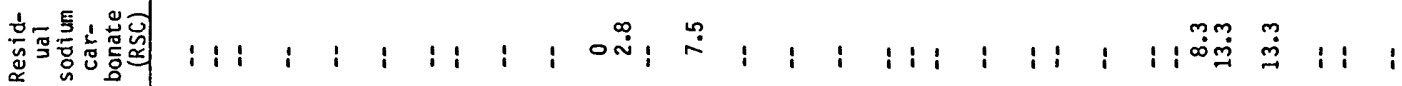

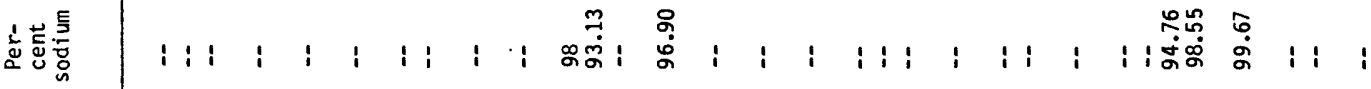

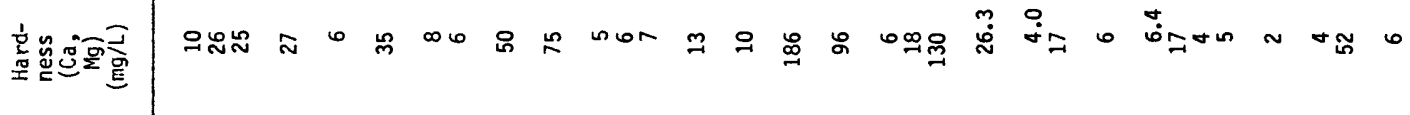

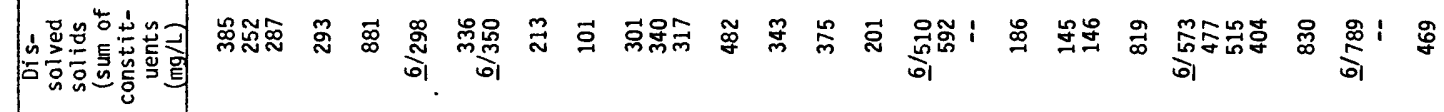

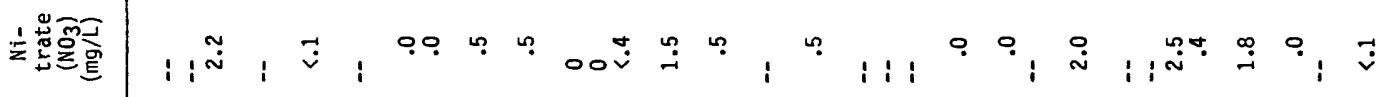

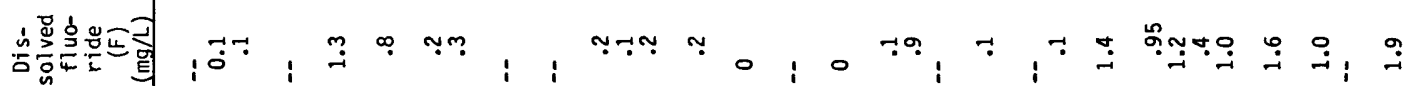

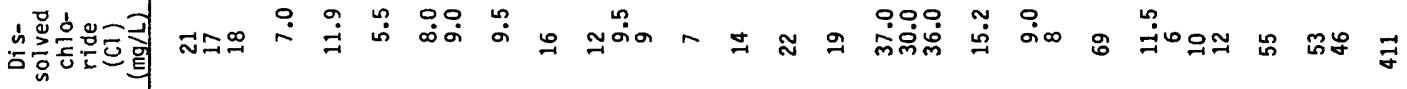

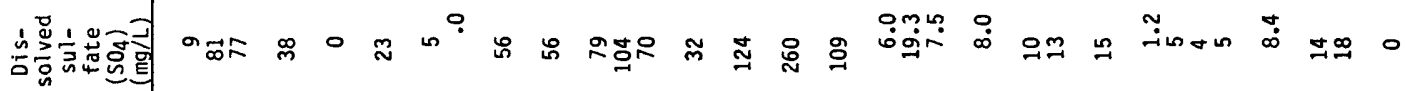

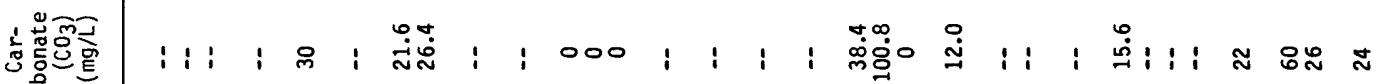

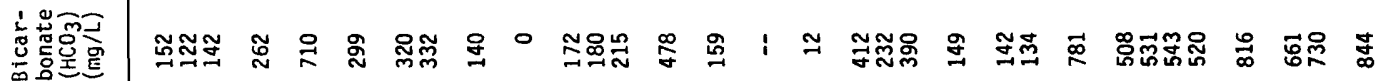

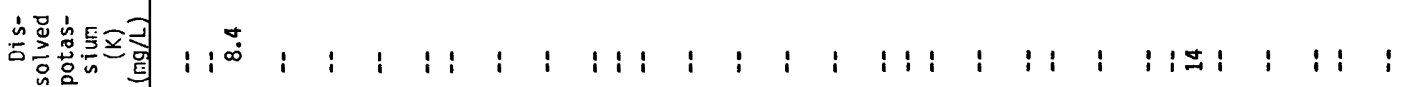

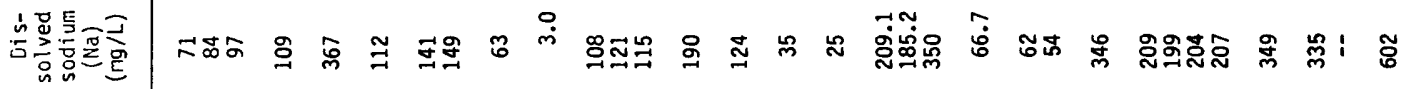

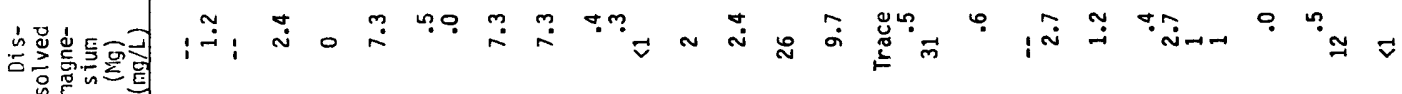

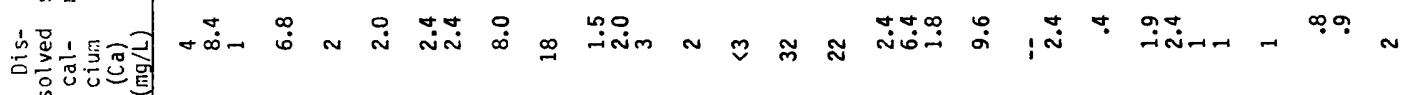

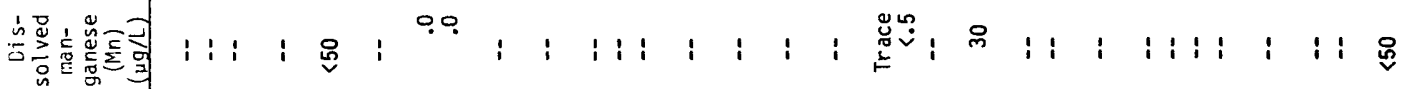

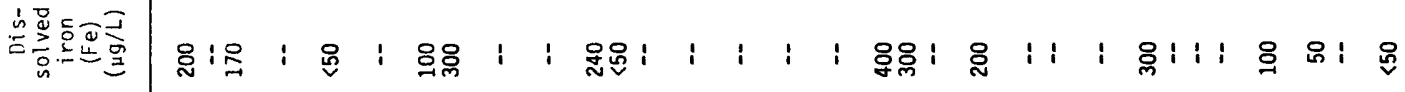

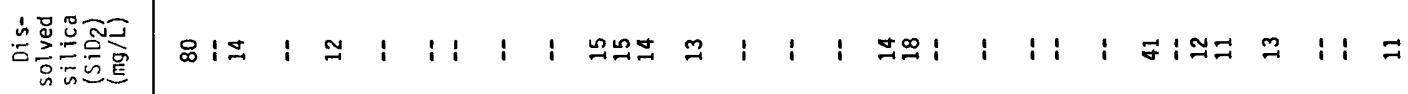
ঋ में

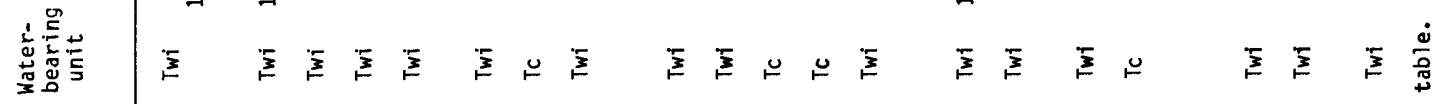

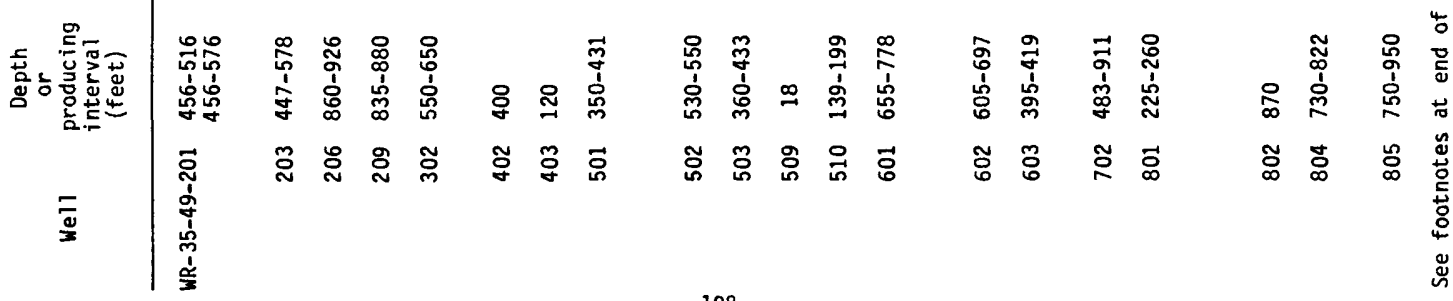




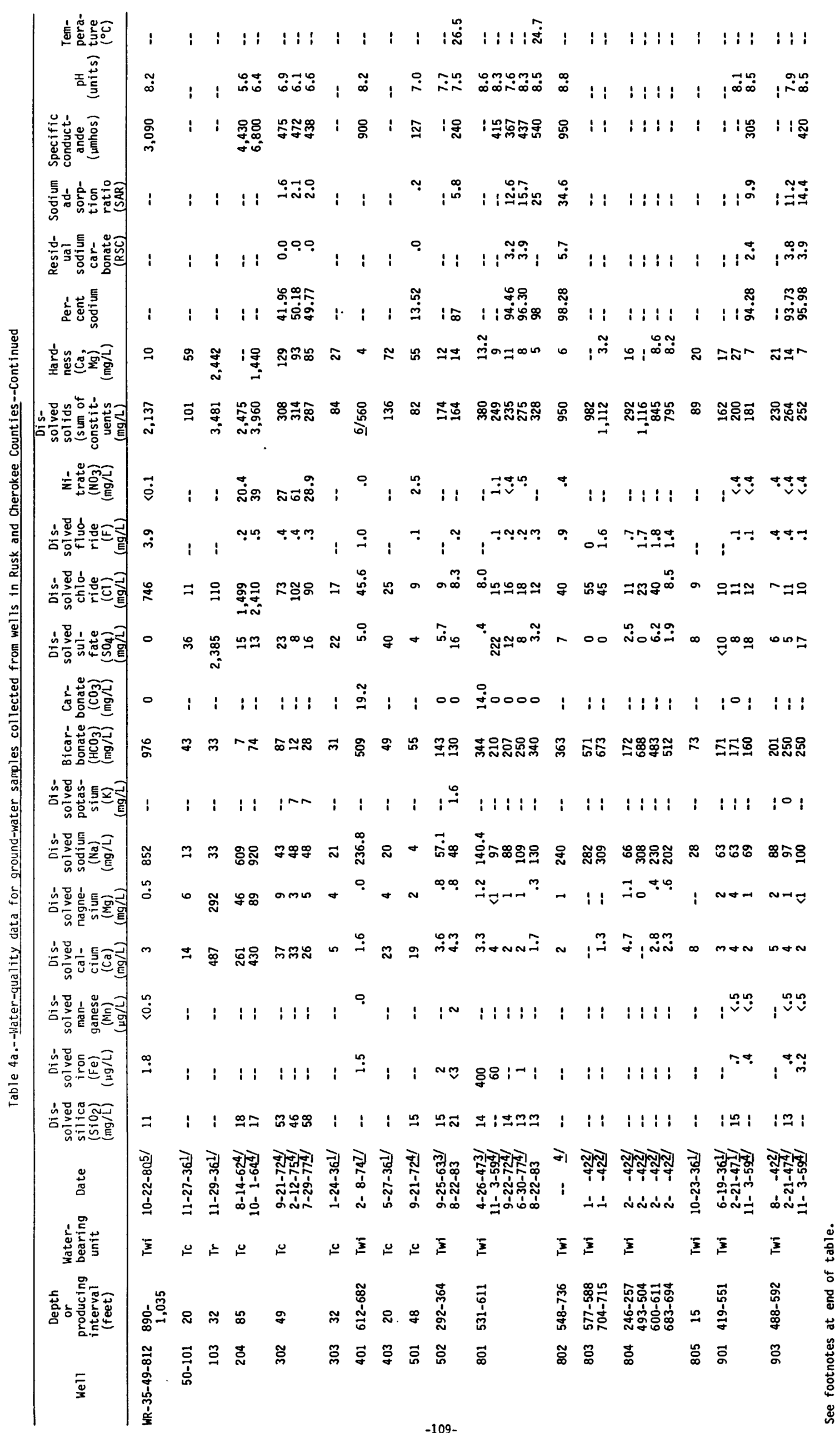




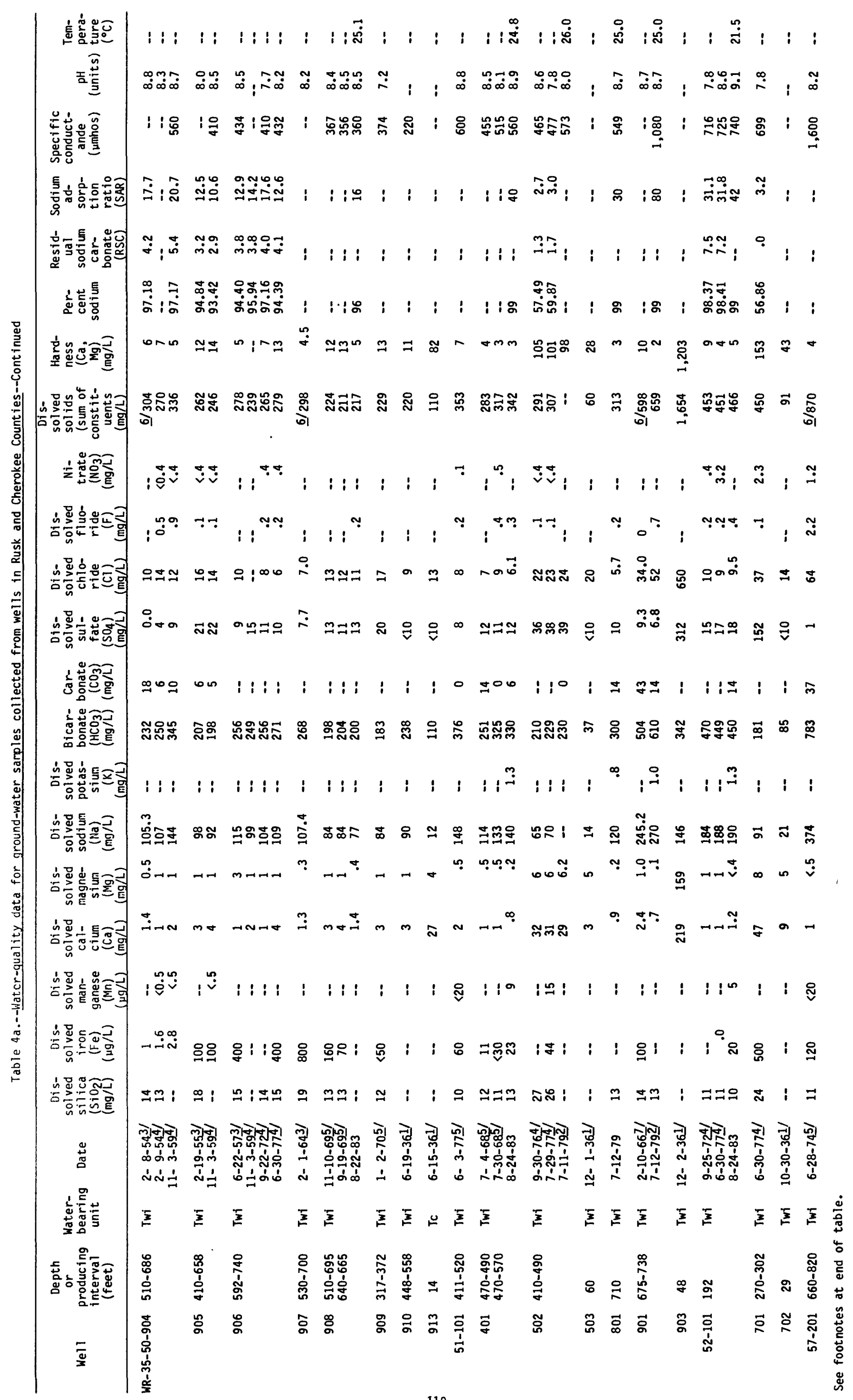




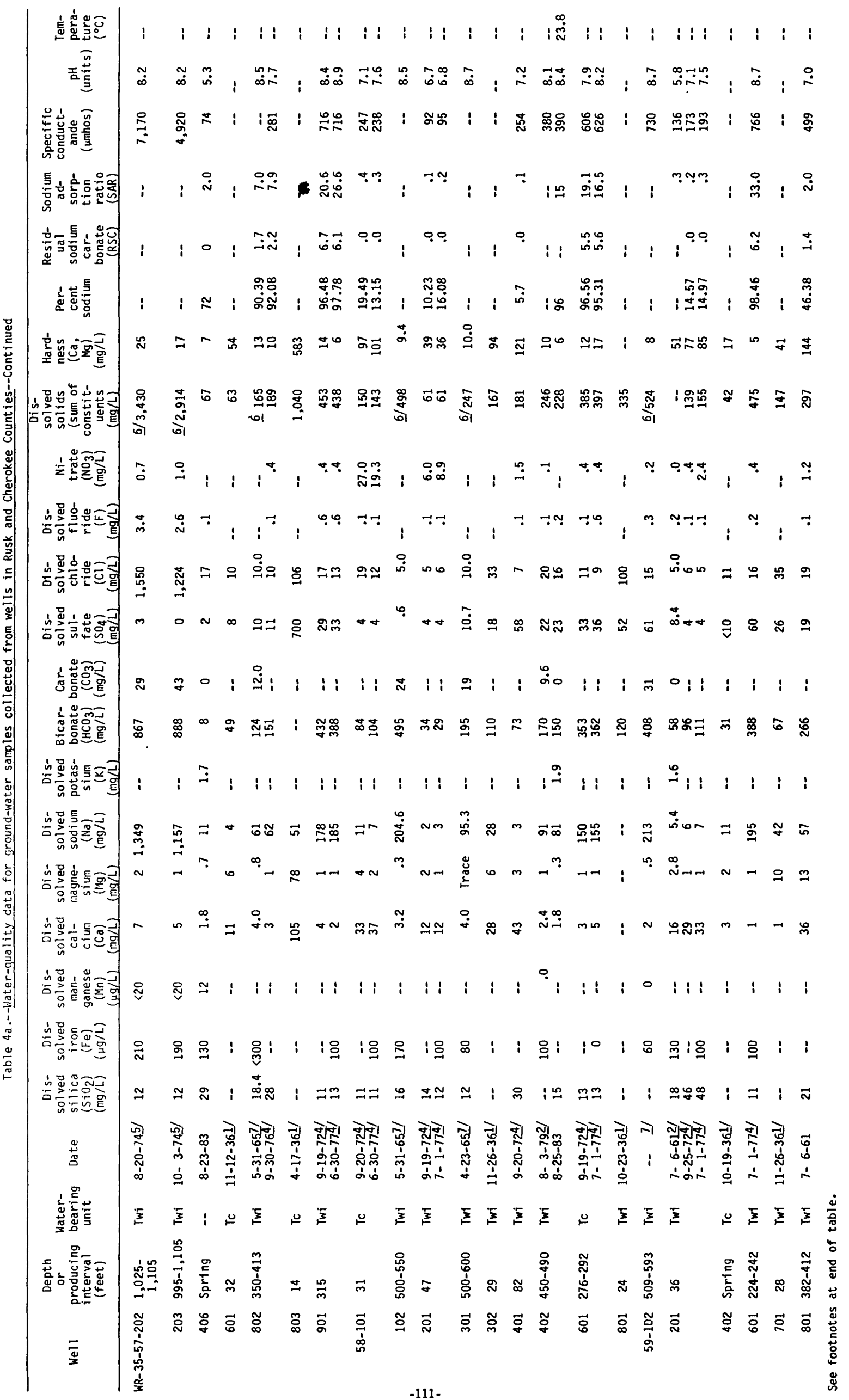




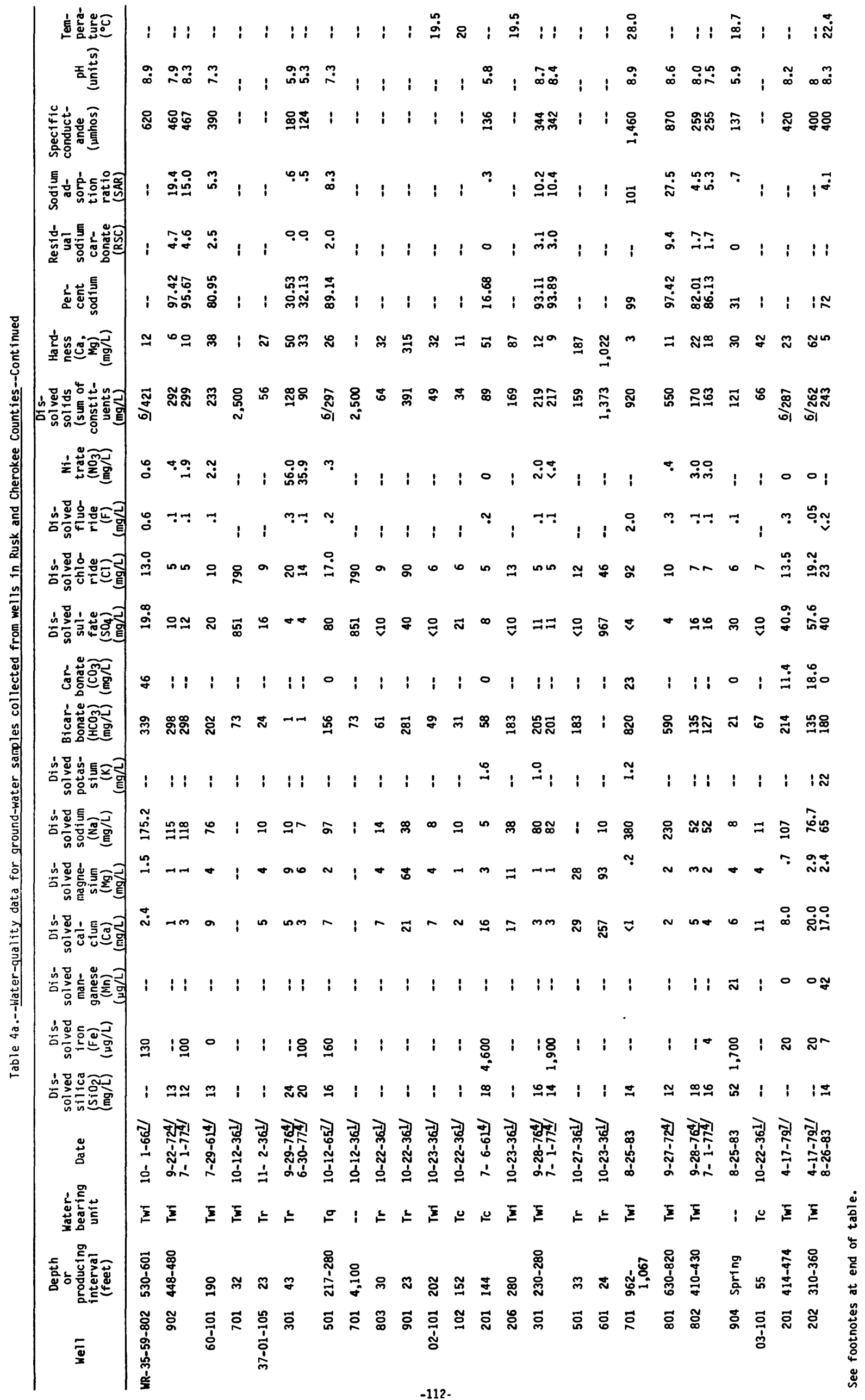




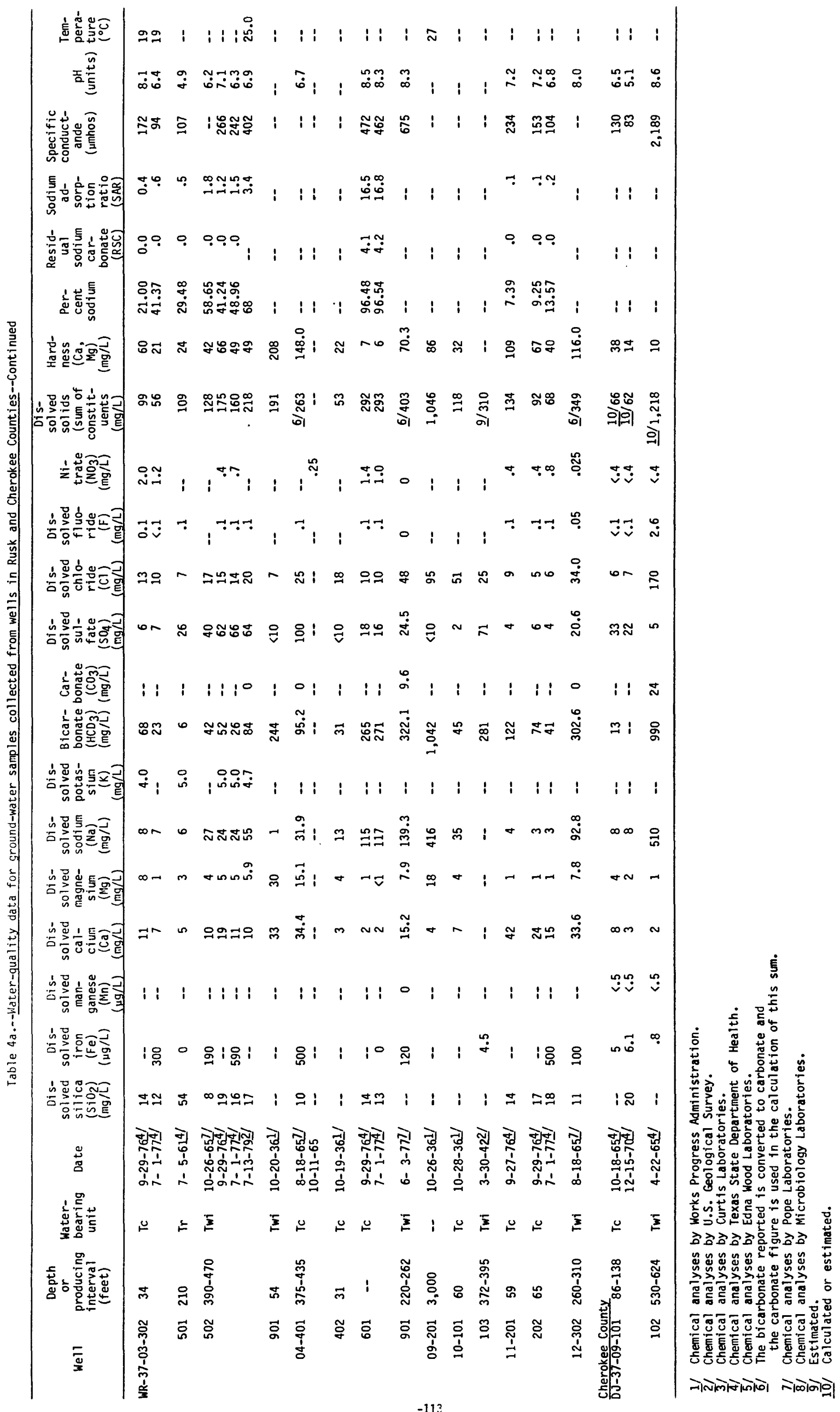




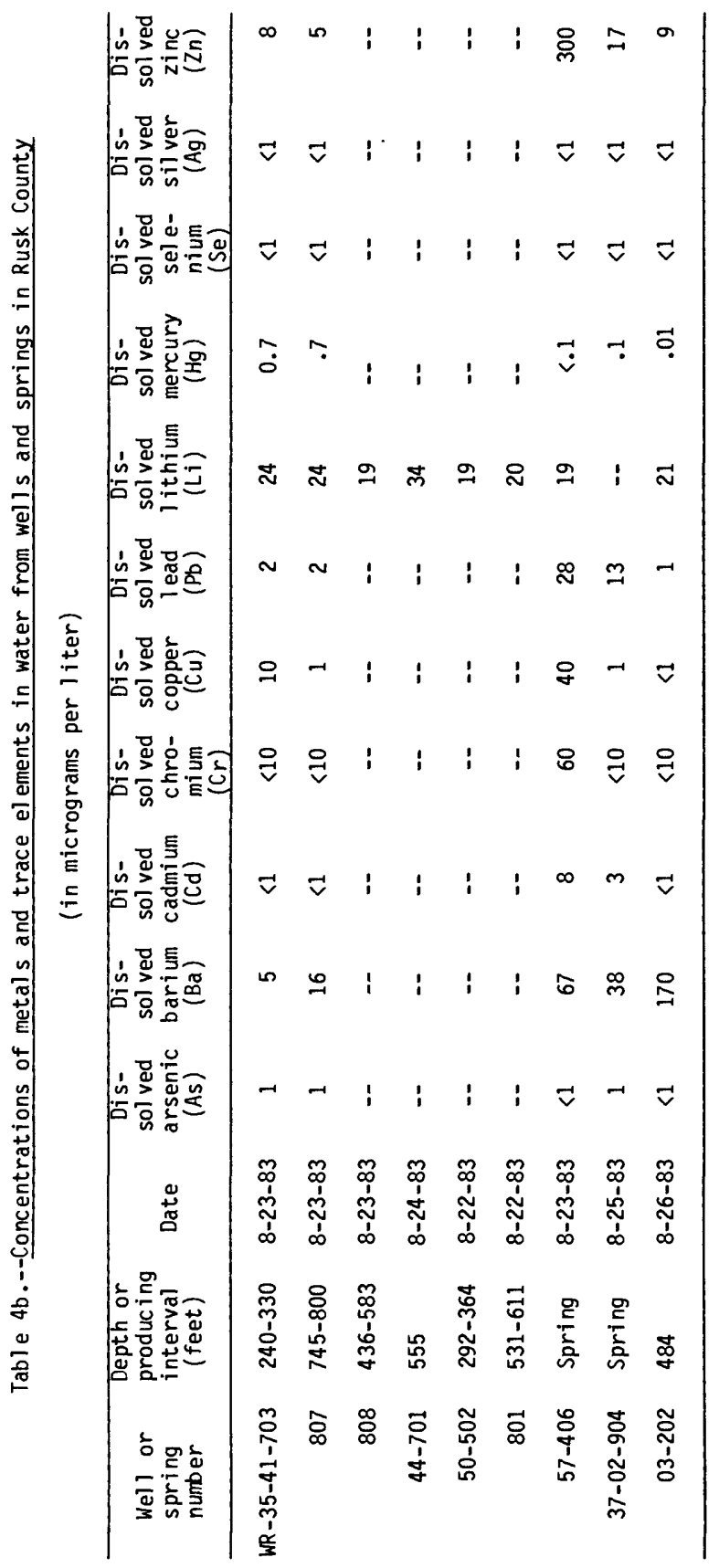

-114- 
Table 8.--Source and significance of selected constituents and properties commonly reported in water analyses II

(mg/L, milligrams per liter; $\mu \mathrm{g} / \mathrm{L}$, micrograms per liter; micromhos, micromhos per centimeter at $25^{\circ}$ Celsius) Constituent or property Source or cause Significance

Silica $\left(\mathrm{SiO}_{2}\right)$

Iron

Calcium

(Ca)

Magnesium (Mg)

Sodium (Na)
Silicon ranks second only to oxygen in abundance in the Earth's crust. Contact of natural waters with silica-bearing rocks and soils usually resuits in a concentration range of about 1 to 30 $\mathrm{mg} / \mathrm{L}$; but concentrations as large as $100 \mathrm{mg} / \mathrm{L}$ are common in waters in some areas.

Iron is an abundant and widespread constituent of many rocks and soils. Iron concentrations in natural waters are dependent upon several chemical equilibria processes including oxidation and reduction; precipitation and solution of hydroxides, carbonates, and sulfides; complex formation especially with organic material; and the metabo1 ism of plants and animals. Dissolved-iron concentrations in oxygenated surface waters seldom are as much as $1 \mathrm{mg} / \mathrm{L}$. Some ground waters, unoxygenated surface waters such as deep waters of stratified lakes and reservoirs, and acidic waters resulting from discharge of industrial wastes or drainage from mines may contain considerably more iron. Corrosion of iron casings, pumps, and pipes may add iron to water pumped from wells.

Calcium is widely distributed in the common minerals of rocks and soils and is the principal cation in many natural freshwaters, especially those that contact deposits or soils originating from limestone, dolomite, gypsum, and gypsiferous shale. Calcium concentrations in freshwaters usually range from zero to several hundred milligrams per liter. Larger concentrations are not uncommon in waters in arid regions, especially in areas where some of the more soluble rock types are present.

Magnesium ranks eight among the elements in order of abundance in the Earth's crust and is a common constituent in natural water. Ferromagnesian minerals in igneous rock and magnesium carbonate in carbonate rocks are two of the more important sources of magnesium in natural waters. Magnesium concentrations in freshwaters usualiy range from zero to several hundred milligrams per liter; but larger concentrations are not uncommon in waters associated with limestone or dolomite.

Sodium is an abundant and widespread constituent of many soils and rocks and is the principal cation in many natural waters associated with argillaceous sediments, marine shales, and evaporites and in sea water. Sodium salts are very soluble and once in solution tend to stay in solution. Sodium concentrations in natural waters vary from less than $1 \mathrm{mg} / \mathrm{L}$ in stream runoff from areas of high rainfall to more than $100,000 \mathrm{mg} / \mathrm{L}$ in ground and surface waters associated with halite deposits in arid areas. In addition to natural sources of sodium, sewage, industrial effluents, oilfield brines, and deicing saits may contribute sodium to surface and ground waters.
Although silica in some domestic and industrial water supplies may inhibit corrosion of iron pipes by forming protective coatings, it generally is objectionable in industrial supplies, particularly in boiler feedwater, because it may form hard scale in boilers and pipes or deposit in the tubes of heaters and on steamturbine blades.

Iron is an objectionable constituent in water supplies for domestic use because it may adversely affect the taste of water and beverages and stain laundered clothes and plumbing fixtures. According to the National Secondary Drinking Water Regulations proposed by the U.S. Environmental Protection Agency (1977b), the secondary maximum contamination level of iron for public water systems is $300 \mu \mathrm{g} / \mathrm{L}$. Iron also is undesirable in some industrial water supplies, particularly in waters used in highpressure boilers and those used for food processing, production of paper and chemicals, and bleaching or dyeing of textiles.

Calcium contributes to the total hardness of water. Small concentrations of calcium carbonate combat corrosion of metallic pipes by forming protective coatings. Calcium in domestic water supplies is objectionable because it tends to cause incrustations on cooking utensils and water heaters and increases soap or detergent consumption in waters used for washing, bathing, and laundering. Calcium also is undesirable in some industrial water supplies, particularly in waters used by electroplating, textile, pulp and paper, and brewing industries and in water used in high-pressure boilers.

Magnesium contributes to the total hardness of water. Large concentrations of magnesium are objectionable in domestic water supplies because they can exert a cathartic and diuretic action upon unacclimated users and increase soap or detergent consumption in waters used for washing, bathing, and laundering. Magnesium also is undesirable in some industrial supplies, particularly in waters used by textile, pulp and paper, and brewing industries and in water used in high-pressure boilers.

Sodium in drinking water may impart a salty taste and may be harmfui to persons suffering from cardiac, renal, and circulatory diseases and to women with toxemias of pregnancy. Sodium is objectionable in boiler feedwaters because it may cause foaming. Large sodium concentrations are toxic to most plants; and a large ratio of sodium to total cations in irrigation waters may decrease the permeability of the soil, increase the pH of the soil solution, and impair drainage. 
Table 8.--Source and significance of selected constituents and properties commonly reported in water analyses--Cont inued

Constituent or property Source or cause

Significance

Potassium Although potassium is only slightly less common (K)

Alkalinity

Sulfate $\left(\mathrm{SO}_{4}\right)$

Chloride (Cl)

Fluoride (F) than sodium in igneous rocks and is more abundant in sedimentary rocks, the concentration of potassium in most natural waters is much smaller than the concentration of sodium. Potassium is liberated from silicate minerals with greater difficulty than sodium and is more easily adsorbed by clay minerals and reincorporated into solid weathering products. Concentrations of potassium more than $20 \mathrm{mg} / \mathrm{L}$ are unusual in natural freshwaters, but much larger concentrations are not uncommon in brines or in water from hot springs.

Alkalinity is a measure of the capacity of a water to neutralize a strong acid, usually to $\mathrm{pH}$ of 4.5 , and is expressed in terms of an equivalent concentration of calcium carbonate $\left(\mathrm{CaCO}_{3}\right)$. Alkalinity in natural waters usually is caused by the presence ob bicarbonate and carbonate ions and to a lesser extent by hydroxide and minor acid radicals such as borates, phosphates, and silicates. Carbonates and bicarbonates are common to most natural waters because of the abundance of carbon dioxide and carbonate minerals in nature. Direct contribution to alkalinity in natural waters by hydroxide is rare and usually can be attributed to contamination. The alkalinity of natural waters varies widely but rarely exceeds 400 to $500 \mathrm{mg} / \mathrm{L}$ as $\mathrm{CaCO}_{3}$.

Sulfur is a minor constituent of the Earth's crust but is widely distributed as metallic sulfides in igneous and sedimentary rocks. Weathering of metallic sulfides such as pyrite by oxygenated water yields sulfate ions to the water. Sulfate is dissolved also from soils and evaporite sediments containing gypsum or anhydrite. The sulfate concentration in natural freshwaters may range from zero to several thousand milligrams per liter. Drainage from mines may add sulfate to waters by virtue of pyrite oxidation.

Chloride is relatively scarce in the Earth's crust but is the predominant anion in sea water, most petroleum-associated brines, and in many natural freshwaters, particularly those associated with marine shales and evaporites. Chloride salts are very soluble and once in solution tend to stay in solution. Chloride concentrations in natural waters vary from less than 1 $\mathrm{mg} / \mathrm{L}$ in stream runoff from humid areas to more than $100,000 \mathrm{mg} / \mathrm{L}$ in ground and surface waters associated with evaporites in arid areas. The discharge of human, animal, or industrial wastes and irrigation return flows may add significant quantities of chloride to surface and ground waters.

Fluoride is a minor constituent of the Earth's crust. The calcium fluoride mineral fluorite is a widespread constituent of resistate sediments and igneous rocks, but its solubility in water is negligible. Fluoride commonly is associated with volcanic gases, and volcanic emanations may be important sources of fluoride in some areas. The
Large concentrations of potassium in drinking water may impart a salty taste and act as a cathartic, but the range of potassium concentrations in most domestic supplies seldom cause these problems. Potassium is objectionable in boiler feedwaters because it may cause foaming. In irrigation water, potassium and sodium act similarly upon the soil, although potassium generally is considered less harmful than sodium.

Alkaline waters may have a distinctive unpleasant taste. Alkalinity is detrimental in several industrial processes, especially those involving the production of food and carbonated or acid-fruit beverages. The alkalinity in irrigation waters in excess of alkaline earth concentrations may increase the $\mathrm{pH}$ of the soil solution, leach organic material and decrease permeability of the soil, and impair plant growth.

Sulfate in drinking water may impart a bitter taste and act as a laxative on unacclimated users. According to the National Secondary Drinking Water Regulations proposed by the Environmental Protection Agency (1977b) the secondary maximum contaminant level of sulfate for public water systems is $250 \mathrm{mg} / \mathrm{L}$. Sulfate also is undesirable in some industrial supplies, particularly in waters used for the production of concrete, ice, sugar, and carbonated beverages and in waters used in high-pressure boilers.

Chloride may impart a salty taste to drinking water and may accelerate the corrosion of metals used in water-supply systems. According to the National Secondary Drinking Water Reguations proposed by the Environmental Protection Agency (1977b), the secondary maximum contaminant level of chloride for public water systems is $250 \mathrm{mg} / \mathrm{L}$. Chloride also is objectionable in some industrial supplies, particularly those used for brewing and food processing, paper and steel production, and textile processing. Chloride in irrigation waters generally is not toxic to most crops but may be injurious to citrus and stone fruits.

Fluoride in drinking water decreases the incidence of tooth decay when the water is consumed during the period of enamel calcification. Excessive quantities in drinking water consumed by children during the period of enamel calcification may cause a characteristic discoloration (mottling) of the teeth. According to the 
Table 8.--Source and significance of selected constituents and properties

commonly reported in water analyses--Cont inued

Constituent

or property

Source or cause

Significance

Fluoride-- fluoride concentration in fresh surface waters Cont. $\quad$ usually is less than $1 \mathrm{mg} / \mathrm{L}$; but larger concentrations are not uncommon in saline water from oil wells, ground water from a wide variety of geologic terranes, and water from areas affected by volcanism.

Nitrogen A considerable part of the total nitrogen of the Earth is present as nitrogen gas in the atmosphere. Small amounts of nitrogen are present in rocks, but the element is concentrated to a greater extent in soils or biological material. Nitrogen is a cyclic element and may occur in water in several forms. The forms of greatest interest in water in order of increasing oxidation state, include organic nitrogen, ammonia nitrogen $\left(\mathrm{NH}_{4}-\mathrm{N}\right)$, nitrite nitrogen $\left(\mathrm{NO}_{2}-\mathrm{N}\right)$ and nitrate nitrogen $\left(\mathrm{NO}_{3}-\mathrm{N}\right)$. These forms of nitrogen in water may be derived naturally from the leaching of rocks, soils, and decaying vegetation; from rainfall; or from biochemical conversion of one form to another. Other important sources of nitrogen in water include effluent from wastewater treatment plants, septic tanks, and cesspools and drainage from barnyards, feed lots, and fertilized fields. Nitrate is the most stable form of nitrogen in an oxidizing environment and is usually the dominant form of nitrogen in natural waters and in polluted waters that have undergone self-purification or aerobic treatment processes. Significant quantities of reduced nitrogen often are present in some ground waters, deep unoxygenated waters of stratified lakes and reservoirs, and waters containing partially stabilized sewage or animal wastes.

Dissolved solids
Theoretically, dissolved solids are anhydrous residues of the dissolved substance in water. In reality, the term "dissolved solids" is defined by the method used in the determination. In most waters, the dissolved solids consist predominantly of silica, calcium, magnesium, sodium, potassium, carbonate, bicarbonate, chloride, and sulfate with minor or trace amounts of other inorganic and organic constituents. In regions of high rainfall and relatively insoluble rocks, waters may contain dissolved-solids concentrations of less than $25 \mathrm{mg} / \mathrm{L}$; but saturated sodium chloride brines in other areas may contain more than $300,000 \mathrm{mg} / \mathrm{L}$.
National Interim Primary Drinking Water Regulations established by the Environmental Protection Agency (1976) the maximum contaminant level of fluoride in drinking water varies from 1.4 to $2.4 \mathrm{mg} / \mathrm{L}$, depending upon the annual average of the maximum daily air temperature for the area in which the water system is located. Excessive fluoride is also objectionable in water supplies for some industries, particularly in the production of food, beverages, and pharmaceutical items.

Concentrations of any of the forms of nitrogen in water significantly greater than the local average may suggest pollution. Nitrate and nitrite are objectionable in drinking water because of the potential risk to bottle-fed infants for methemoglobinemia, a sometimes fatal illness related to the impairment of the oxygen-carrying ability of the blood. According to the National Interim Primary Drinking Water Regulations (U.S. Environmental Protection Agency, 1976), the maximum contaminant level of nitrate (as $N$ ) in drinking water is 10 $\mathrm{mg} / \mathrm{L}$. Although a maximum contaminant level for nitrite is not specified in the drinking water regulations, Appendix $A$ to the regulations (U.S. Environmental Protection Agency, 1976) indicates that waters with nitrite concentrations (as $\mathrm{N}$ ) greater than $1 \mathrm{mg} / \mathrm{L}$ should not be used for infant feeding. Excessive nitrate and nitrite concentrations are also objectionable in water supplies for some industries, particularly in waters used for the dyeing of wool and silk fabrics and for brewing.

Dissolved-solids values are used widely in evaluating water quality and in comparing waters. The following classification based on the concentratrations of dissolved solids commonly is used by the Geological Survey (Winslow and Kister, 1956).
Classification

Fresh

Slightly saline

Moderately saline

Very saline

Brine concentration $(\mathrm{mg} / \mathrm{L})$

$$
\begin{array}{r}
1,000-3,000 \\
3,000=10,000 \\
10,000-35,000
\end{array}
$$$$
>35,000
$$

The National Secondary Drinking Regulations (U.S. Environmental Protection Agency, 1977b) set a dissolved-solids concentration of 500 $\mathrm{mg} / \mathrm{L}$ as the secondary maximum contaminant leve 1 for public water systems. This level was set primarily on the basis of taste thresholds and potential physiological effects, particularly the laxative effect on unacclimated users. Al though drinking waters containing more than $500 \mathrm{mg} / \mathrm{L}$ are undesirable, such waters are used in many areas where less mineralized supplies are not available without any obvious ill effects. Dissolved solids in industrial water 
Table 8.--Source and significance of selected constituents and properties commonly reported in water analyses--Cont inued

Constituent

or property

Source or cause

Significance

Dissolved

solids--

Cont.

Specific

conductance

Specific conductance is a measure of the ability of water to transmit an electrical current and depends on the concentrations of ionized constituents dissolved in the water. Many natural waters in contact only with granite, well-leached soil, or other sparingly soluble material have a conductance of less than 50 micromhos. The specific conductance of some brines exceed several hundred thous and micromhos.

Hardness as $\mathrm{CaCO}_{3}$

Hardness of water is attributable to all polyvalent metals but principally to calcium and magnesium ions expressed as $\mathrm{CaCO}_{3}$ (calcium carbonate). Water hardness results naturally from the solution of calcium and magnesium, both of which are widely distributed in common minerals of rocks and soils. Hardness of waters in contact with limestone commonly exceeds $200 \mathrm{mg} / \mathrm{L}$. In waters from gypsiferous formations, a hardness of $1,000 \mathrm{mg} / \mathrm{L}$ is not uncommon.

$\mathrm{pH}$

The $\mathrm{pH}$ of a solution is a measure of its hydrogen ion activity. By definition, the $\mathrm{pH}$ of pure water at a temperature of $25^{\circ} \mathrm{C}$ is 7.00 . Natural waters contain dissolved gases and minerals, and the $\mathrm{pH}$ may deviate significantly from that of pure water. Rainwater not affected significantly by atmospheric pollution generally has a $\mathrm{pH}$ of 5.6 due to the solution of carbon dioxide from the atmosphere. The $\mathrm{pH}$ range of most natural surface and ground waters is about 6.0 to 8.5. Many natural waters are slightly basic $(\mathrm{pH}$ 77.0) because of the prevalence of carbonates and bicarbonates, which tend to increase the $\mathrm{pH}$. supplies can cause foaming in boilers; interfere with clearness, color, or taste of many finished products; and accelerate corrosion. Uses of water for irrigation also are limited by excessive dissolved-solids concentrations. Dissolved solids in irrigation water may adversely affect plants directly by the development of high osmotic conditions in the soil solution and the presence of phytoxins in the water or indirectly by their effect on soils.

The specific conductance is an indication of the degree of mineralization of a water and may be used to estimate the concentration of dissolved solids in the water.

Hardness values are used in evaluating water quality and in comparing waters. The following classification is commonly used by the Geological Survey.

$\frac{\text { Hardness }\left(\mathrm{mg} / \mathrm{L} \text { as } \mathrm{CaCO}_{3}\right)}{0-60}$

$6-60$

$61-120$

$121-180$

Classification

Soft

Moderately hard

Hard

Very hard

Excessive hardness of water for domestic use is objectionable because it causes incrustations on cooking utensils and water heaters and increased soap or detergent consumption. Excessive hardness is undesirable also in many industrial supplies. (See discussions concerning calcium and magnesium.)

The $\mathrm{pH}$ of a domestic or industrial water supply is significant because it may affect taste, corrosion potential, and water-treatment processes. Acidic waters may have a sour taste and cause corrosion of metals and concrete. The National Secondary Drinking Water Regulations (U.S. Environmental Protection Agency, 1977b) set a $\mathrm{pH}$ range of 6.5 to 8.5 as the secondary maximum contaminant level for public water systems.

$1 /$ Most of the material in this table has been summarized from several references. For a more thorough discussion of the source and significance of these and other water-quality properties and constituents, the reader is referred to the following additional references: American Public Health Association and others (1975); Hem (1970); McKee and Wolf (1963); National Academy of Science, National Academy of Engineering (1973); National Technical Advisory Committee to the Secretary of the Interior (1968); and U.S. Environmental Protection Agency (1977a). 